\title{
National Contingency Plan for Response to Unusual Marine Mammal Mortality Events
}

Dean M. Wilkinson

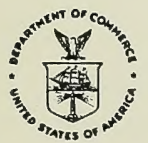

U.S. Department of Commerce

National Oceanic and Atmospheric Administration National Marine Fisheries Service

NOAA Technical Memorandum NMFS-OPR-9

September 1996 


\section{ACKNOWLEDGMENTS}

The comments received on the draft version of this plan were particularly useful. It would be impossible to list everyone who contributed, but a number of people who made major contributions should be recognized. Foremost among these, the Working Group on Unusual Marine Mammal Mortality Events provided input throughout the process and reviewed multiple drafts. The members of the Working Group are: Dr. Joseph Geraci, Chair, Dr. Gregory Bossart; Dr. Leslie Dierauf, Dr. Romona Haebler; Dr. Robert Hofman; Dr. Thomas Lipscomb; Dr. James Mead; Dr. Thomas O’Shea; Dr. John Reif; Dr. Thomas Roffe; Dr. Linda Schlater; Dr. Randall Wells; Dr. Thomas Williams; Kate Wynne; Nina Young; and Jeffrey Horwath, the U.S. Fish and Wildlife Service Liaison to the Working Group. Extensive comments from the Marine Mammal Commission markedly imptoved the final product. U.S. Fish and Wildlife Service Regional Offices were responsible for much of the material on manatees and sea otters. Christine Pattison of the California Department of Fish and Game made a major contribution to the material on sea otters. Pam Chelgren-Koterba of the NOAA Hazardous Materials Response and Assessment Division provided guidance on oil and chemical spill response. Having directed the response to two mortality events, Ann Colbert of the National Marine Fisheries Service's (NMFS) Charleston Laboratory made a number of suggestions based on practical experience. Finally, the material in the addenda is in large part the work of the NMFS Regional Stranding Coordinators-Nancy Haley, Jeff Brown, Joe Cordaro, Brent Norberg, and Linda Shaw.

\section{Suggested citation:}

Wilkinson, Dean M. 1996. National contingency plan for response to unusual marine mammal mortality events. U.S. Dep. Commer., NOAA Tech. Memo. NMFS-OPR-9, 118 p. 


\section{National Contingency Plan for Response to Unusual Marine Mammal Mortality Events}

\section{Dean M. Wilkinson}

National Marine Fisheries Service, NOAA

Office of Protected Resources

1335 East-West Highway

Silver Spring, MD 20910

NOAA Technical Memorandum

NMFS-OPR-9

September 1996

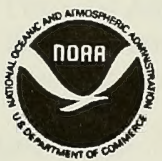

U.S. Department of Commerce Michael Kantor, Secretary

National Oceanic and Atmospheric Administration D. James Baker, Under Secretary for Oceans and Atmosphere National Marine Fisheries Service

Rolland E. Schmitten, Assistant Administrator for Fisheries
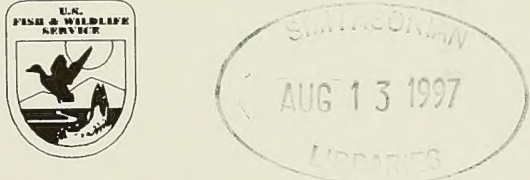

U.S. Department of the Interior Bruce Babbit, Secretary

U.S. Fish and Wildlife Service John G. Rogers Jr., Acting Director 



\section{TABLE OF CONTENTS}

EXECUTIVE SUMMARY

\section{INTRODUCTION}

Marine Mammal Health and Stranding Response Act

Development of a Contingency Plan

Unusual Mortality Events

Baseline Information and Stranding Networks

Objectives of Contingency Plan

Discharges of Oil and Hazardous Chemicals

Resources

PUBLIC HEALTH AND WELFARE

Safety and Hygienic Precautions

Aviation Safety

Carcass Disposal

Live Animals

ADVANCE PLANNING

Equipment

Protocols and Training 14

$\begin{array}{ll}\text { Compilation of Lists } & 15\end{array}$

$\begin{array}{lr}\text { Early Monitoring Activities } & 16\end{array}$

INITIAL STEPS

Criteria for Determining an Unusual Mortality Event 18

Appointment of Onsite Coordinator 18

Notifications to Accelerate Response 19

Assessment of Capacities, Capabilities 20

Aerial Surveys 23

Environmental Parameters 24

Data Requirements 26

ADMINISTRATIVE TASKS

Financial Administration $\quad 27$

Public Information 28

$\begin{array}{lr}\text { Tracking of Animals and Samples } & 29\end{array}$

LIVE ANIMALS

Available Facilities and Requirements 31

Release Conditions $\quad 32$ 
TISSUE COLLECTION, PRESERVATION, AND SHIPPING

Protocols and Available Trained Personnel

Sea Otter Provisions

Shipment and Tracking of Samples $\quad 34$

Specific Types of Analyses

Blood $\quad 34$

Histopathology $\quad 35$

Life History $\quad 35$

Biotoxins 36

Heavy Metals/Organic Contaminants $\quad 37$

$\begin{array}{ll}\text { Virology, Bacteriology, Mycology } & 37\end{array}$

Conditions on Disclosure of Results 38

SPECIAL CIRCUMSTANCES

Litigation $\quad 39$

$\begin{array}{lr}\text { Live Captures } & 39\end{array}$

Independent Research $\quad 41$

Mass Strandings $\quad 41$

POST-EVENT ACTIVITIES

Report $\quad 43$

Follow-up Activities $\quad 43$

Tissue Access $\quad 44$

Post-Event Monitoring $\quad 44$

REFERENCES $\quad 45$

ADDENDA

Stranding Network Members $\quad 48$

$\begin{array}{ll}\text { Federal Beachfront Agencies } & 78\end{array}$

State Wildlife Resource Agencies $\quad 84$

State Public Health Organizations $\quad 86$

Native American Organizations $\quad 88$

Facilities for Holding Live Animals $\quad 102$

Sources for Gross Necropsies and Tissue Preparation 109

$\begin{array}{ll}\text { Veterinary Colleges } & 116\end{array}$ 


\section{EXECUTIVE SUMMARY}

The Marine Mammal Health and Stranding Response Act requires the preparation of a contingency plan for response to unusual marine mammal mortality events. Such events may be caused by a variety of factors including: oil discharges and releases of anthropogenic chemicals; naturally occurring biotoxins; changes in environmental conditions; and infectious agents. Mortality events also vary in their characteristics. The cause may be known or not known. There may be live marine mammals requiring care or only dead animals on the beaches. Depending on the type of event and characteristics, the appropriate response will vary, and a contingency plan must be sufficiently broad to provide for a response to a wide variety of circumstances.

The Act provides that the response to an unusual mortality event will be directed by an Onsite Coordinator. The Onsite Coordinator will be either a National Marine Fisheries Service (NMFS) or U.S. Fish and Wildlife Service (FWS) Regional Director or an individual designated by the Regional Director. The primary purpose of this plan is to provide a blueprint to the Onsite Coordinator for the response to mortality events. It provides guidance to Regional Directors of NMFS and FWS on: steps to be taken to protect the public health and welfare; advance planning for such events; steps to identify the cause(s) of an event; and measures to determine the biological significance of an event. The plan contains lists of contacts for response, facilities that are capable of holding live animals, tissue collection and preparation, and analyses that may be necessary to determine causes of death and the effects that physical, chemical, or biological factors may have on marine mammal populations.

This plan is divided into several sections corresponding to different activities that may be required in a response to an unusual mortality event.

Because public health and welfare is of paramount concern in any mortality event, a short section (Section II) on this issue precedes all other substantive sections.

Although not technically part of a response, section three addresses materials and information that should be generated in advance. The success of a response may be dependent on having necessary equipment in place, well trained personnel, and general protocols for tissue collection. In preparation for unusual marine mammal mortality events, Regional Directors should:

1) Be aware of possible causes for unusual marine mammal mortality events (p. 3) and the criteria used to designate such events (p. 18);

2) Identify individuals with the necessary abilities to be Onsite Coordinators (p. 18-19);

3) Identify and preposition equipment that might be necessary to respond to a mortality event (p. 13-14);

4) Distribute protocols for gross necropsy and tissue collection to those who are likely to be involved in a response to a mortality event (p. 14-15);

5) Provide training to individuals likely to be involved in a response. Such training should include:

a) Safety measures (p. 9-12);

b) Utilization of protocols for gross necropsy, tissue collection, preparation, and shipment for different analyses (p. 33-38);

c) Chain-of-custody procedures; 
6) Establish and maintain lists of contacts, including:

a) Notifications to be made to accelerate initial response (p. 15-16, 19-20, and Addenda A-E);

b) Facilities with capacity, equipment, and expertise to treat live animals

(Addendum E);

c) Facilities/individuals with the expertise necessary to conduct gross necropsies and prepare tissues for a variety of analyses (Addendum F);

d) Facilities/individuals with the expertise necessary to conduct specific analyses

(p. 34-38); and

7) In order to respond to situations where live-capture operations may be necessary to determine the cause(s) of a mortality event, identify (if necessary, train) individuals with the expertise necessary for live capture operations and identify sources of equipment that would be required for such an exercise (p. 39-40).

Sections four through nine deal with procedures in responding to an unusual mortality event. It should be noted that under certain circumstances, another entity may be responsible for response. In the case of a known oil discharge or release of a hazardous substance, either the Coast Guard or the Environmental Protection Agency will assume responsibility for a response. When the reason for a mortality event is determined to be a direct human interaction, e.g., incidental mortality in fisheries or animals being deliberately killed, the appropriate actions should be taken by either the management or enforcement sections of the two agencies and are outside the context of this plan.

Section four (IV) (p. 18-26) covers steps that should be taken to accelerate response and assess capabilities and needs.

During past mortality events, NMFS has found that it is extremely difficult for the same individual to conduct the scientific side of an investigation and deal with the administrative side of an investigation. Section five (V) (p. 27-30) prescribes the appointment of personnel whose primary responsibility will be administrative.

Section six (VI) (p. 31-32) covers special circumstances when there may be live animals during a mortality event.

Section seven (VII) (p. 33-38) details analyses that might be required, lists individuals with the skills necessary to conduct necropsies and collect tissues for detailed analysis, and locations where specific analyses may be performed. Although additional analyses may be required depending on the nature of the event, basic information is contained on the following: blood from live animals; histopathology; life history; biotoxins; heavy metals/organic contaminants; and virology/bacteriology/mycology.

There are special circumstances that may require additional actions. The eighth section (VIII) discusses procedures for dealing with: the possibility of litigation; live capture to gain information not available from stranded animals; requests from independent researchers for materials; and mass strandings.

The final section (IX) details responsibilities after an event is concluded. The Onsite Coordinator will prepare a report containing results of scientific investigations, findings as to the cause of a mortality event, an assessment of the impact on the affected population(s), and recommendations for subsequent monitoring or management activities. In addition, participants should receive communications expressing appreciation for their roles in responding to the mortality event. 
Basic steps in responding to an event include:

1) Based on the criteria listed on page 18, the Working Group on Unusual Marine Mammal Mortality Events is responsible for determining when an unusual mortality event is occurring.

2) When notified by the Working Group that an unusual mortality event is occurring, the Assistant Administrator for Fisheries or, when species under FWS jurisdiction are involved, the Director of the U.S. Fish and Wildlife Service will appoint the appropriate Regional Director as Onsite Coordinator. The Regional Director may designate another qualified individual to serve in this capacity.

3) To accelerate response, the Onsite Coordinator will provide notification and instruction to:
a) Stranding Network members (Addendum A);
b) Federal beachfront agencies (Addendum B);
c) State wildlife resource agencies (Addendum C);
d) Coast Guard District Headquarters (p. 15-16);
e) Public health agencies (if necessary) (Addendum D);
f) Appropriate local governmental units;
g) NMFS, FWS, and National Biological Service laboratories;
h) Native American groups (as appropriate) (Addendum E).

4) As necessary, the Onsite Coordinator will establish an Administrative Team (p. 27-30) to:

a) Handle contracting and other financial affairs;

b) Respond to inquiries from the media and general public; and

c) Handle collection of data, data entry, and tracking of samples.

5) The Onsite Coordinator is responsible for checking to determine if environmental conditions may have precipitated a mortality event or resulted in detection of a larger number of mortalities than would normally be the case. These conditions include:
a) Current anomalies (p. 24);
b) Sea surface temperatures (p. 24);
c) Toxic phytoplankton blooms (p. 24); and
d) Shellfish monitoring (p. 24).

6) The Onsite Coordinator shall assess basic needs for response including: adequacy of response network in terms of coverage, ability to conduct necropsies, and ability to collect tissue samples; available equipment; and, if live animals are involved in the mortality event, the capacity and capabilities of rehabilitation facilities. If any of these is less than adequate, steps shall be taken to supplement existing resources.

7) If the cause(s) of an event is known, the Onsite Coordinator will make provision for:

a) Adequate care of live animals (p. 31-32);

b) Collection, preparation, analysis, and archiving of tissues and voucher specimens (p. 33-38). If litigation is possible, provisions for maintaining a proper chain of custody are necessary;

c) Assessing the impact of the mortality event on wild populations; and

d) If feasible, put mitigation measures in place. 
8) If the cause(s) of an event is unknown, all of the previous steps are necessary. In addition, in consultation with the Working Group, the Onsite Coordinator will put investigative measures in place including:

a) Making provision for aerial surveys, if necessary, to locate fresh carcasses and/or determine the extent of a mortality event (p. 23);

b) Defining specific tissue collection and preparation protocols. Making arrangements for specific analyses to be performed and for shipment of samples to facilities performing analyses (p. 33-38);

c) Compiling and analyzing results.

9) After a mortality event is over and results of analyses have been received, the Onsite Coordinator shall file a final report containing compilation and, as appropriate, interpretation and correlations of data sets and analytical results to document the cause(s) and biological significance of an event. If appropriate, the report shall contain recommendations for post-event monitoring. In addition, the report shall analyze the response to the event and provide suggestions for improving future responses. (p. 43-44).

Immediately following this page, a decision tree is provided covering the various activities that may be necessary in a response. 


\begin{tabular}{|l|}
\hline \multicolumn{2}{|c|}{ Appointment of On-site Coordinator } \\
\hline Notifications \\
a. Stranding Networks (Addendum A) \\
b. Federal Beach Front Agencies (Addendum B) \\
c. State Wildlife Resource Agencies (Addendum C) \\
d. Coast Guard District Headquarters (pp. 15-16) \\
e. Local Government Agencies \\
f. NMFS, FWS, NBS Laboratories \\
g. State Public Health Agencies, if necessary (Addendum D) \\
\hline
\end{tabular}

g. State Public Health Agencies, if necessary (Addendum D)

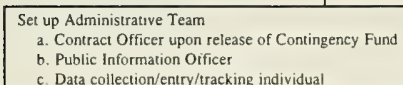

c. Data collection/entry/tracking individual
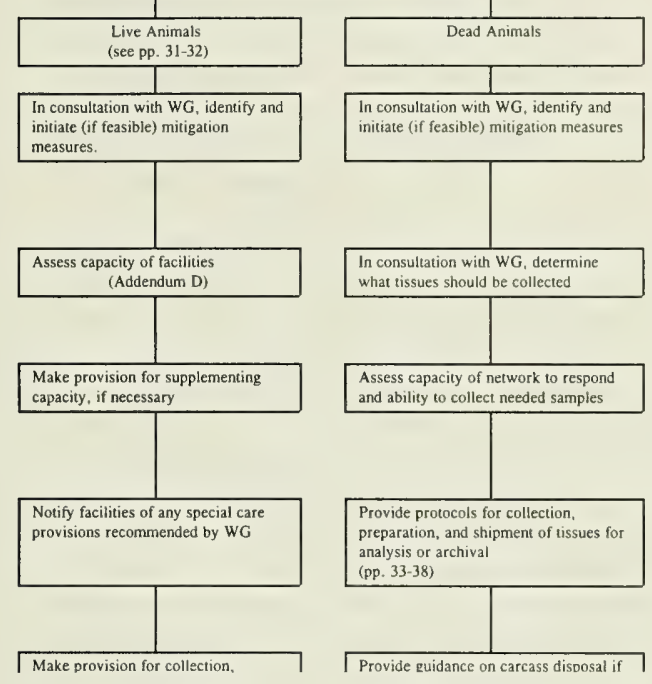

In consultation with WG, identify and initiate (if feasible) mitigation measures

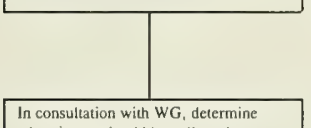

what tissues should be collected

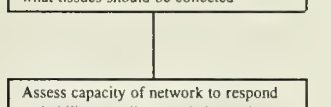

and ability to collect needed samples

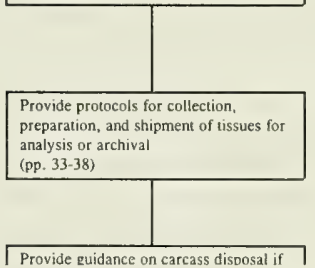

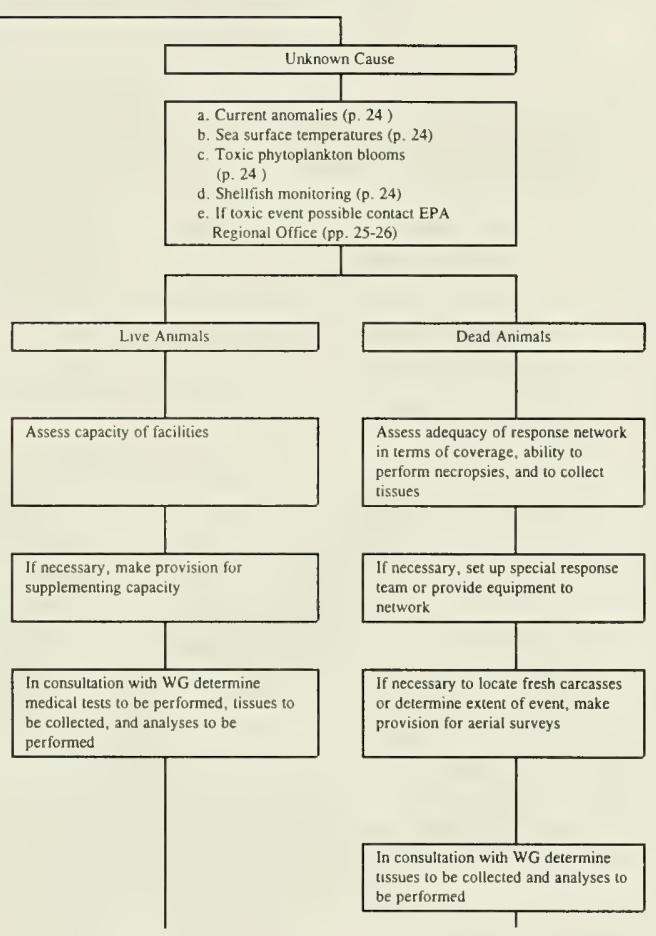





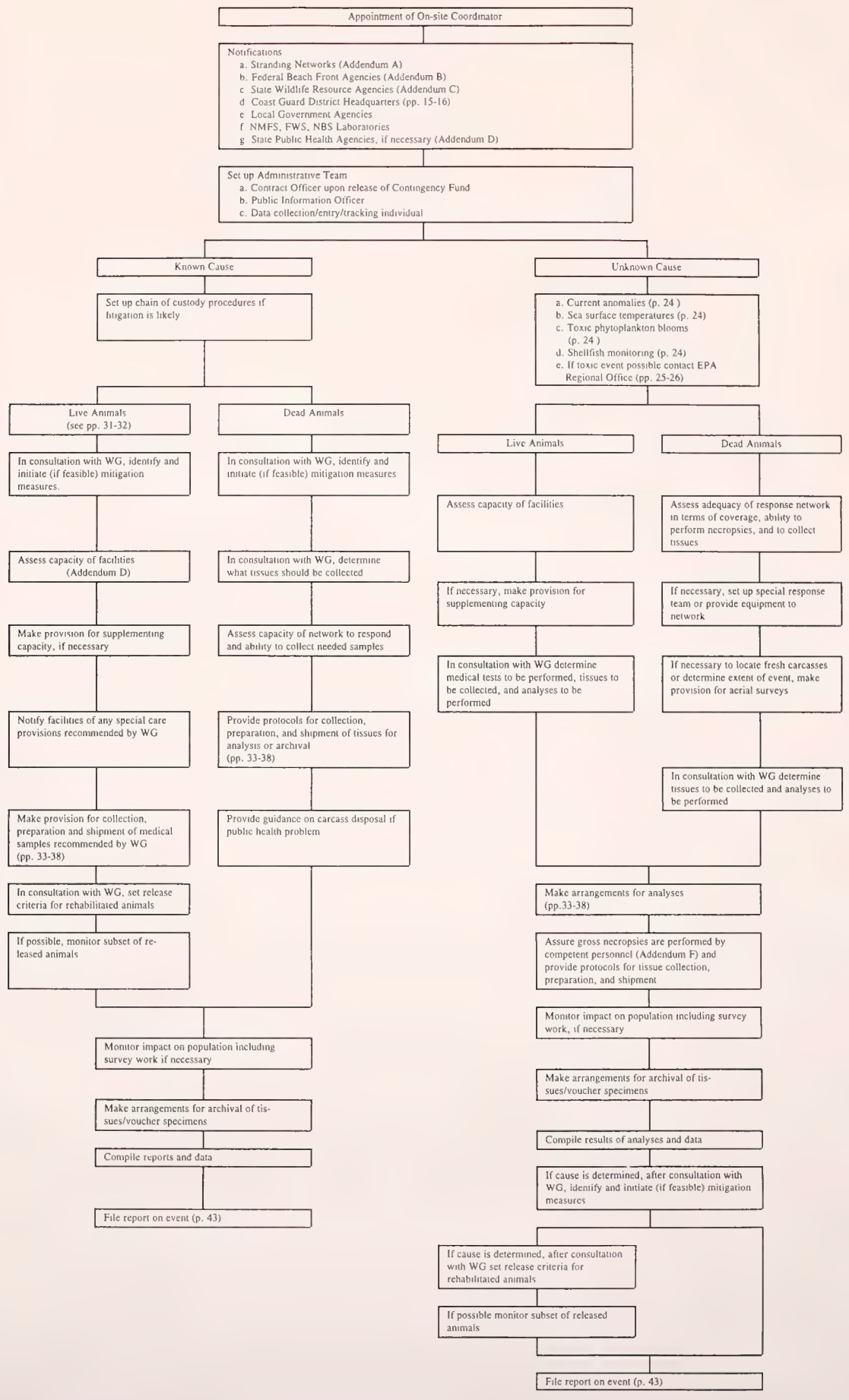

Table I 



\section{INTRODUCTION}

Much of the impetus for the passage of the Marine Mammal Protection Act (MMPA) in 1972 (P.L. 92-522) stemmed from concern over the direct killing of marine mammals and mortality associated with fisheries. In the two decades following enactment, increasing attention has been given to more indirect human impacts on marine mammals, including those associated with anthropogenic contaminants. The deaths of large numbers of bottlenose dolphins, Tursiops truncatus, on the U.S. east coast in 1987-88 created concern that the Federal Government was inadequately prepared to respond to unusual mortality events, explain their occurrence, and take corrective action.

\section{Marine Mammal Health and Stranding Response Act}

In response to increasing public concern, the Congress passed the Marine Mammal Health and Stranding Response Act in 1992 (P.L. 102-587, 16 U.S.C. 1421-1421(h)). The Act created a new Title 3 to the Marine Mammal Protection Act that was redesignated as Title 4 by §24(b)(1) of P.L. 103-238. Sections 301-309 were redesignated as $\$ \S 401-409$. The Act contained three basic elements. Sections 402-403 deal with generating scientific information from stranded animals and upgrading the capabilities of the marine mammal stranding networks. Section 402 also mandates development of criteria for release of rehabilitated animals. In response to the problem of adequate baseline information, section 407 provides for the establishment of a National Marine Mammal Tissue Bank, provisions for analysis of tissues for contaminants, and creation of a data base.

Section 404 provides a framework for responding to unusual mortality events. It creates a multidisciplinary Marine Mammal Unusual Mortality Event Working Group to provide guidance to the Secretaries of the Interior and Commerce in determining when such an event is occurring, in developing a response plan to such an event, and in developing a contingency plan for responding to such an event. The Working Group was constituted in April 1993.

The Act also provides the framework for responding to mortality events which includes the appointment of an Onsite Coordinator to coordinate response activities. The Onsite Coordinator shall be a Regional Director of either the National Marine Fisheries Service (NMFS) or the United States Fish and Wildlife Service (FWS) or someone designated by the Regional Director. The House Report describes the Onsite Coordinator's responsibilities: directing of the response process; managing personnel and facility usage; acting as a liaison with central offices; and coordinating public relations. Section 405 creates a fund to be used for special costs incurred in responding to unusual mortality events.

The development of this contingency plan was mandated by $\$ 404(\mathrm{~b})$ which states:

"(1) IN GENERAL.--The Secretary (of Commerce) shall in consultation with the Secretary of the Interior and the unusual mortality event working group, and after an opportunity for public review and comment, issue a detailed contingency plan for responding to any unusual mortality event.

"(2) CONTENTS.--The contingency plan required under this subsection shall include-- 
"(A) a list of persons, including stranding network participants, at a regional, State, and local level who can assist the Secretary in implementing a coordinated and effective response to an unusual mortality event;

"(B) the types of marine mammal tissues and analyses necessary to assist in diagnosing causes of unusual mortality events;

"(C) training, mobilization, and utilization procedures for available personnel, facilities, and other resources necessary to conduct a rapid and effective response to unusual mortality events; and

"(D) such requirements as are necessary to--

"(i) minimize death of marine mammals in the wild and provide appropriate care of marine mammals during an unusual mortality event;

"(ii) assist in identifying the cause or causes of an unusual mortality event;

"(iii) determine the effects of an unusual mortality event on the size estimates of the affected populations of marine mammals; and

"(iv) identify any roles played in an unusual mortality event by physical, chemical, and biological factors, including contaminants."

In scope, the contingency plan must include all coastal regions of the United States and the adjacent waters under United States jurisdiction. It must be adequate to address all species of marine mammals. With the exceptions noted below, NMFS is primarily responsible for response to mortality events involving cetaceans and pinnipeds (excluding walrus), and FWS is primarily responsible for sea otters, walrus, manatees, and polar bears. Depending on the circumstances, other units of government may have responsibilities. As an example, if a mortality event should create a serious public health problem, a variety of other local, state, and Federal agencies would have responsibilities. The House Report accompanying the legislation states that the plan should be specific to species (or groups of species). Because approaches for determining the cause of an event--collecting, preserving, and analyzing tissues--are likely to be similar among the range of species, this contingency plan provides a general outline, with species differences highlighted only when appropriate. The species-specific approach is most appropriate for rehabilitating live animals (Dierauf, 1990). For example, the physical facilities needed to care for pinnipeds are less complicated than those needed for cetaceans or polar bears.

\section{Unusual Mortality Events}

The Act characterizes an unusual mortality event as having the following characteristics: (1) it is unexpected; (2) it involves a significant die-off of any marine mammal population; and (3) it demands an immediate response. In addition to the obvious circumstances involving significant numbers of marine mammal deaths within a short period of time, the Working Group determined that there were two other instances when a response would be justified--when there is a mass stranding of unusual species of cetaceans and when even small numbers of a severely endangered marine mammal species appear to be affected. Although steady declines of a population over time warrant investigation, such occurrences are part of each agency's more general charge under the Act. Clearly, the structure of the Act indicates that its purpose is to address acute mortality. Rapid large-scale mobilization and appointment of an Onsite Coordinator may not be the appropriate method for addressing a chronic population decline. 
Factors that can cause an unusual mortality event include, but are not limited to:

1) Impacts including toxicity and fouling caused by oil discharges or chemical releases or toxic runoff of anthropogenic chemicals or other impacts, such as immunological dysfunction, caused by chronic exposure to pollutants that may become apparent in an acute mortality event;

2) Naturally occurring biotoxins;

3) Changes in environmental conditions such as an El Niño or a sudden change in water temperature;

4) Parasitic or infectious disease agents; or

5) Mortalities caused by direct human interactions such as bycatch in fisheries or deliberate taking. As noted below, such a mortality factor must be taken into account when trying to determine a cause of an event, but, once confirmed, response becomes a management or enforcement responsibility.

A contingency plan must include provisions for detecting and responding to each of these conditions. The response priorities will vary depending on whether or not the cause of the event is known, the number and species of animals involved, or if the event poses a threat to public health and safety. The major task during an El Niño may be to rescue and rehabilitate emaciated animals. In other instances, attention may focus on determining a cause(s), which may be far more difficult. As an example, it may be difficult to determine if contaminant burdens have compromised a population's immune systems to the point where the marine mammals are more vulnerable to the normal range of pathogens. Such a determination often is difficult even in human epidemiology, and far less is known about stressors and immune systems of marine mammals.

Although mortality events have received more publicity since the 1987-88 mortality of bottlenose dolphins along the mid-Atlantic coast, an examination of the historical record since 1978 shows that such events are not uncommon. Table 1 lists known mortality events over this period and scientific literature pertinent to those events.

\section{Baseline Information and Stranding Networks}

The 1987-88 mortality event raised some significant questions concerning response to such events. It drew attention to the need for baseline information. As an example, some of the dolphins died with high tissue levels of organochlorines, the significance of which could not be determined because there was a dearth of information with which to make comparisons (Geraci, 1989). It was also obvious that resources needed to respond to such an event were not initially available. The response might have been more effective if a team of specialists and protocols for tissue collection, preservation, and analysis had been in place.

Following the 1987-88 mortality event, NMFS took steps to address these weaknesses. A National Marine Mammal Tissue Bank was established to collect and archive tissues from marine mammals that can be used for retrospective analysis of contaminant levels. Section 407 of the Marine Mammal Health and Stranding Response Act provides a legislative mandate for the 
1978

Hawaiian monk seals (Monachus schauinslandi)

$1979-80$ Harbor seals (Phoca vitulina)

1982

1982
Harbor seals (Phoca virulina)

Manatees (Trichechus manaius) (Associated mortalities of fish and double-crested cormorants)

Several species of pinnipeds

Califomia sea lions (Zalophus californianus) (Smaller outbreaks of the same disease occurred in 1988 and 1991)

Sea Otters (Enhydra lutris) (Two humans contracted paralytic shellfish poisoning in the same area from blue mussels)

Dolphins, primarily Tursiops truncatus and some Sousa chinensis (Associated mortalities of fish, dugongs, birds, and sea turtles)

Humpback whales

Baikal seals (Phoca sibirica)

Bottlenose dolphins (Tursiops truncatus)

Harbor seals (Phoca vitulina)

Sea Otters (Enhydra lutris) and some harbor seals (Phoca vitulina)

Striped dolphins (Stenella coeruleoalba)

Northeast phocids

Bottlenose dolphins (Tursiops truncatus) (Associated mortalities of fish and birds. Pesticide aldicart detected in trace amounts in water.)

Several species of pinnipeds

Harbor seals (Phoca vitulina), Steller sea lions (Eumatopias jubatus), and California sea lions (Zalophus californianus)

Bottlenose dolphins (Tursiops truncatus) delphis)

Common dolphins (Delphinus delphis) and Califomia sea lions (Zalophus californianus) (Associated mortalities of birds)

Manatees (Trichechus manatus)
Common dolphins (Delphinus
Ciguatoxin and

maitotoxin

Influenza $A$ virus

Influenza $\mathrm{A}$ vinus

Brevetoxin

El Niño

Leptospirosis

Saxitoxin

Cause not determined

Saxitoxin

Morbillivirus

Brevetoxin

Morbillivirus

Phocine distemper virus

Oil spill--Exxon Valdez

Morbillivirus

Phocine distemper virus

Cause not determined

El Niño

Human interactiongunshot wounds

Morbillivirus

Cause not determined

Probable toxic discharge

Gulf of Califomia, Mexico

Cape Cod, Massachusetts

Cape Cod, Massachusetts

Southwest Florida

Pacific coast from Peru through California

California

Kodiak Island, Alaska
Gilmartin, 1987

Geraci et al., 1982

Hinshaw et al., 1984

O'Shea et al., 1991

Trillmich and Ono, 1991

Dierauf et al., 1985

DeGange and Vacea, 1989

Investigation ongoing
Northeast U.S, coast

Lake Baikal, USSR

U.S. east coast

North Sea

Prince William Sound, Alaska

Medierranean Sea

U.S. east coast

Calhoun and Aransas Counties, Texas

Califomia

Central Washington coast

Pers.comm. K. Hanni

Pers. comm. B. Norberg

Gulf of Mexico

Lipscomb et al., in press

Pers. comm. J. Cordaro

Vidal and Gallo, in press
Southwest Florida egional Organization for the Protection of the Marine Environment, 1986

Geraci et al., 1989

Grachev et al., 1989

Geraci, 1989

Lipscomb et al., 1994

Osterhaus and Vedder, 1988

Loughlin, 1994

Domingo et al., 1990

Geraci et al., 1990

Pers. comm A Jennings

California coast

Pers. comm R. Tumer 
Tissue Bank. The Tissue Bank is located at the National Institute of Standards and Technology (NIST) in Gaithersburg, Maryland. The tissues are collected following a rigorous protocol and stored in liquid nitrogen. Because of uncertainties as to whether singly stranded animals are representative of populations as a whole and whether health conditions may have an impact on results from analyses, collections for the Tissue Bank currently have been restricted to presumably healthy marine mammals either taken in the subsistence harvest by Alaskan natives, incidentally taken in fisheries, or, in the case of cetaceans, mass stranded. To ensure uniform standards of analyses, NIST has set up a Quality Assurance program involving interlaboratory comparison exercises and the preparation of Standard Reference Materials.

As a second step toward improving response, a program review of the Marine Mammal Stranding Networks was conducted. To respond to marine mammal strandings, networks of volunteers have been authorized by NMFS for cetaceans and pinnipeds and by FWS for manatees and sea otters. Members of the Stranding Networks are issued Letters of Authorization by the NMFS Regional Offices. NMFS Regions are shown on the next page. Most of the volunteers are professionals with marine mammal experience. They may be researchers affiliated with State agencies or universities, individuals associated with public display facilities, or individuals with animal rehabilitation experience. The members of the Networks rehabilitate sick and injured marine mammals, and collect basic biological data and tissues from dead marine mammals. Addendum A contains a list of Stranding Network members by State.

Network members are the first line of response to any marine mammal strandings. They have capabilities to treat animals and collect tissues for analyses. Therefore, they are likely to be heavily involved in any response to an unusual mortality event. The program review identified strengths and weaknesses of the Networks and made recommendations to improve the administration of the Networks by NMFS and enhance the capabilities of individual members (Wilkinson, 1991).

\section{Objectives of Contingency Plan}

To develop the expertise necessary to respond to mortality events, NMFS established a Task Group on Unusual Marine Mammal Mortalities in April 1991. The Task Group was similar in function to the Working Group on Unusual Marine Mammal Mortalities set up under the Marine Mammal Health and Stranding Response Act. Whenever an unusual event was suspected, NMFS consulted with the members of the Task Group for guidance on what steps should be taken to respond to the event. The Task Group was consulted seven times between April 1991 and April 1993, when it was succeeded by the statutory Working Group.

The purpose of this contingency plan is to outline actions that can/should be taken to:

1) Protect the public health and welfare;

2) Investigate and identify the cause(s) of a mortality event;

3) Minimize or mitigate the effects of a mortality event on the affected population(s) and provide for the rehabilitation of individual animals; and

4) Determine the impact of a mortality event on the affected population(s). 


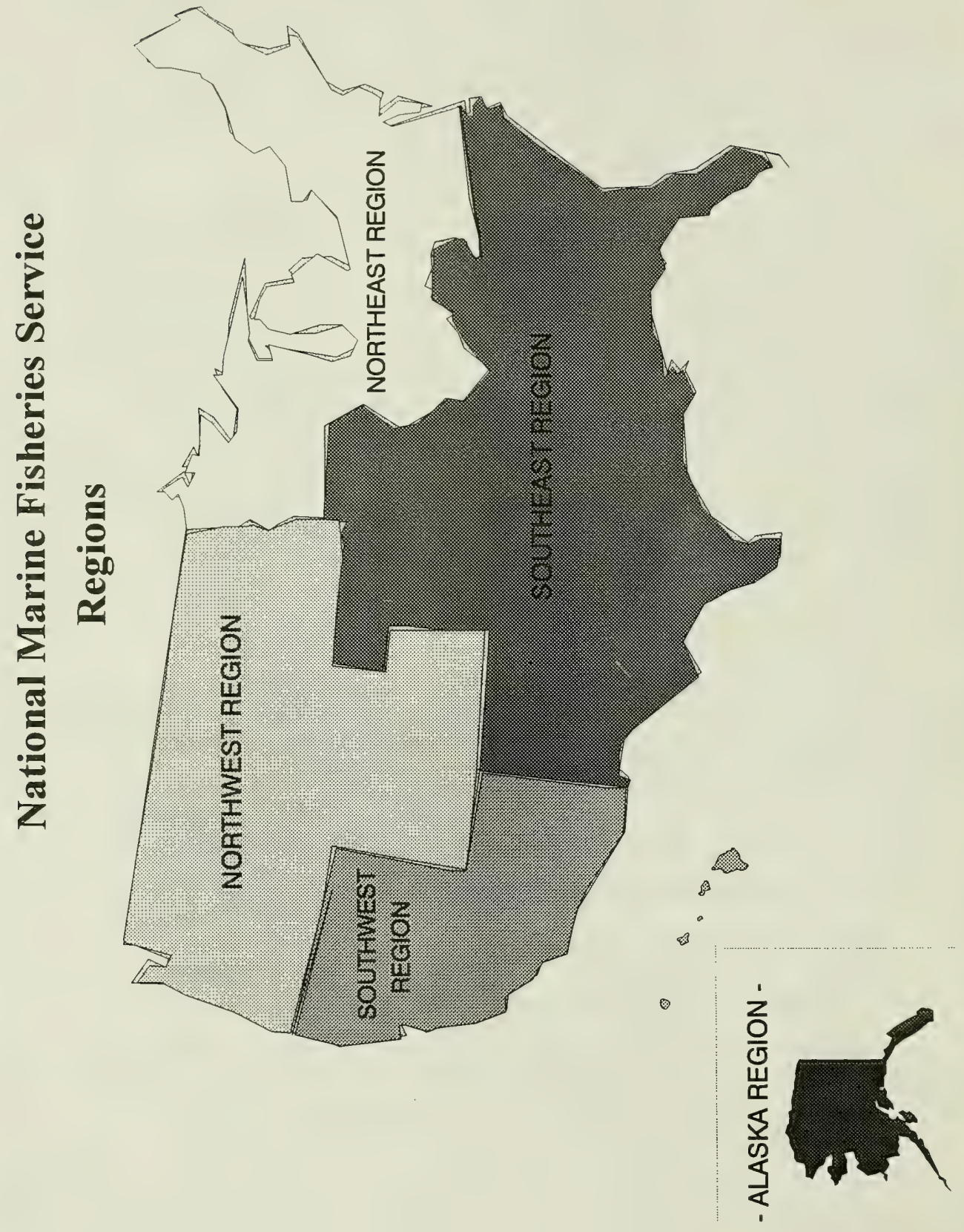


Although there is considerable public interest in appropriate response to marine mammal mortality events, achieving these goals is the responsibility of the Onsite Coordinator, and this plan is intended to provide guidance for the Onsite Coordinator by detailing responsibilities, providing a general framework for response, and listing activities and resources.

Because of variations in appropriate response actions and available resources, a national contingency plan must be flexible. A prescribed protocol applicable to all events could actually inhibit an effective response. A contingency plan should identify actions and resources needed to increase the level and timeliness of response and provide procedures for a range of analyses that may be required. In some instances, the emphasis may be on mitigation, rehabilitation, documentation of effects, and assessment of impacts on the population(s). In others, the highest priority will be determination of the cause(s).

\section{Discharges of Oil and Hazardous Chemicals}

There is one type of unusual mortality event during which procedures laid out in the Act including responsibilities, appointment of Onsite Coordinators, and funding will not be followed. Responses to oil discharges or releases of hazardous substances are governed by either the Clean Water Act, as amended, the Oil Pollution Act of 1990, or the Comprehensive Environmental Response, Compensation and Liability Act. The U.S. Coast Guard has primary responsibility for response to spills and releases within or threatening the coastal zone. Coast Guard District Offices are listed on pages 15-16. Although not specifically addressed in the Marine Mammal Health and Stranding Response Act, the House Report stated that the authority of the Act would not supersede, modify, or limit the duties and responsibilities conveyed by the other Acts. Such an interpretation is logical in order to avoid competing and conflicting response activities and contingency plans.

Many of the resources identified for response under the Marine Mammal Health and Stranding Response Act also will be utilized in spill emergencies. An effort has been made by the Working Group to help those developing regional and state oil spill contingency plans identify those individuals and facilities that can provide treatment for impacted marine mammals and collect tissues for analyses. In the northeast, California, and Alaska, oil spill response procedures and personnel to be utilized closely parallel those set out in this contingency plan.

\section{Resources}

This contingency plan assumes that adequate funding for a response will be available. The Act created a special fund to be applied for response to mortality events. In addition to authorizing appropriations, it allows acceptance of private donations. Such donations can be sent to:

Office of Protected Resources

National Marine Fisheries Service

1335 East-West Highway

Silver Spring, MD 20910-3226

ATTN. Unusual Mortality Event Fund

Telephone: (301) 713-2322 
To date no funds have been appropriated or donated to the fund. Although advance planning can enhance the response to a mortality event, lack of funds or the necessity to reprogram funds can delay or limit the magnitude of the response. 
The first priority in responding to an Unusual Marine Mammal Mortality Event is public health and welfare. There are several ways in which a marine mammal mortality event could have an impact on public health or safety.

\section{Safety and Hygienic Precautions}

Although not common, if basic safety and hygienic precautions are not observed, stranded animals can cause physical injury or transmit disease to humans. Under $\$ 300.150$ of the National Oil and Hazardous Substances Pollution Contingency Plan (40 CFR Part 300) which references the OSHA regulation at 29 CFR 1910.120, participants in a response to oil discharges or releases of hazardous chemicals are required to have OSHA training. Most of the individuals responding to mortality events under the Marine Mammal Health and Stranding Response Act will have previous experience in handling stranded animals. Stranding Network members have received safety protocols and reminders of safety precautions and should not need special training. Despite such steps, however, even the most experienced personnel may forget safety precautions. If less experienced personnel are utilized, the Onsite Coordinator should ensure that they are informed of safety measures. When the cause of an event is unknown, extra precautions should be taken. In January 1992, a letter on safety precautions was distributed to Stranding Network members. If a mortality event should occur, participants in a response should be reminded of the points contained in that letter:

1) Recognize your physical limitations. Guard against overexposure to cold water and weather as well as to sun and heat. Do not attempt to lift more weight than you can without injury.

2) Precautions against injury should be taken at the site of a live stranding. Pinnipeds can be aggressive, and respondents should guard against being bitten. Distance is the only safeguard against the thrashing flukes of a cetacean.

3) Wear gloves when touching animals, conducting dissections, and handling tissues and fluids. Cover any cuts, scratches, or abrasions with waterproof protective dressings before handling animals or parts. Use waterproof outerwear to protect clothing from fluid contamination.

4) Wash your skin after handling either live or dead animals. Clothing and footwear should also be washed.

5) If you are bitten, cut, or injured while handling an animal or tissues, seek professional medical attention. Do not rely on first aid alone.

6) If you become ill after handling a marine mammal or tissues from a marine mammal, inform your physician that you have had contact with such animals. Some of the diseases that could be transmitted are rarely encountered (e.g., sealfinger), and may not be correctly diagnosed if a physician is not provided with an adequate history. 


\section{Aviation Safety}

In the section below entitled Initial Steps, there are two circumstances when aerial survey work may be undertaken: to help in locating fresh carcasses and to determine the possible impact of an event on population abundance. Some Federal agencies currently have safety guidelines for aviation, and Federal employees should strictly follow these guidelines. In some instances, however, private individuals and aircraft may be used. Such individuals also should be conscious of safety measures. To provide guidance to them, the following list has been adapted from draft guidelines prepared by the National Biological Service. As a guiding principle, safety is paramount. Mission urgency should never override sound safety requirements.

General Requirements:

1) The mission to be flown shall be necessary, and flight planning for the mission shall be appropriate.

2) Only personnel necessary to the mission are to be on board the aircraft.

3) The configuration of the aircraft will be appropriate to the mission.

4) The pilot must have proficiency and experience for the type of mission to be flown.

5) The weather must be good enough to accomplish the mission safely. If weather conditions deteriorate so that safety becomes an issue, the mission will be terminated.

6) All passengers will follow instructions from the pilot.

Safety Briefing:

The pilot shall conduct a safety briefing prior to each flight. If the pilot does not do so, it is the responsibility of passengers to remind the pilot of this responsibility. The subjects of the briefing should include:

Mandatory

1) Location and operation of the fire extinguisher.

2) Location and contents of the first aid kit.

3) Location and operation of the emergency exits.

4) Location and operation of the Emergency Locator Transmitter.

5) Emergency crash and aircraft exiting procedures.

6) Proper use of seatbelts and shoulder harnesses. 
7) Location and use of survival gear.

Recommended

1) Location and operation of emergency fuel shut off.

2) Location and operation of avionics master switch and electrical master switch.

3) Location and operation of communications radio.

Personal Safety Equipment:

1) Adequate hearing protection, e.g., earplugs, earphones, or helmets equipped with headphones.

2) Helmet.

3) Fire-retardant clothing. Note: Nylon, dacron, or polyester garments or undergarments which have direct contact with the wearer's skin should not be worn because they present an unacceptable exposure to post-mishap fire injury.

4) Personal flotation devices must be worn for over water work in single-engine airplanes and helicopters. Personal Flotation Devices need not be worn but must be immediately accessible to each person in multiengined aircraft operating over water.

5) Properly fitting anti-exposure suits must be worn in all single-engine aircraft and must be readily accessible to occupants of multi-engined aircraft when water temperatures are estimated to be $50^{\circ} \mathrm{F}\left(10^{\circ} \mathrm{C}\right)$ or less.

\section{Carcass Disposal}

Carcasses of dead animals could be a source of either pathogens or toxins that might affect wildlife and domestic animals. Steps should be taken to avoid such possibilities, including proper isolation and disposal of carcasses. In normal circumstances, carcasses sometimes are left on the beach to decompose naturally. If there is the possibility of a transmissible pathogen or serious toxin, unused portions of carcasses should be buried, taken to a sanitary landfill, or fully destroyed by incineration. If carcasses are buried, they should be in an area where fluids will not leach into groundwater and deep enough so that they will not be dug up by scavengers or uncovered by wave action.

\section{Live Animals}

Live animals moved to research or display facilities should be quarantined in an area or enclosure with a separate source of water and waste water run-off. Hygienic measures should be taken to prevent the spread of pathogens to display animals. These should include footbaths, 
protective clothing, washing after handling animals, and changing and disinfecting clothing and footwear.

If a serious health or safety hazard is identified, the Onsite Coordinator will be responsible for issuing special requirements in terms of collecting and handling animals and carcasses, providing quarantine instructions, and setting up specific measures for carcass disposal. In such cases, consideration should be given to appointment of a safety/sanitation officer to assist, monitor, and supervise such activities. 


\section{ADVANCE PLANNING}

The Marine Mammal Health and Stranding Response Act provides that the Onsite Coordinator will be one or more Regional Directors of NMFS or FWS or their designees. Although the Act emphasizes response to unusual mortalities, there are steps that should be taken by Regional Offices well in advance of a mortality event in order to facilitate the response. These include purchase of equipment and development of a list of support services and contacts to be made when such events occur.

In most instances, the individuals best placed to rapidly respond to marine mammal strandings are the members of the Stranding Networks. However, all that is required under Letters of Authorization in normal circumstances is for members to collect basic information such as date and site of a stranding, the species involved, the condition of the animal or carcass, its length and sex, any evidence of human interaction, and disposition of the animal or carcass. Although many of the members work beyond collection of such basic data and collect tissues for research, not all members of the Networks have the equipment and training necessary for necropsy or specialized tissue collection.

\section{Equipment}

Experience with past events has shown that identification of equipment needs, location of vendors, and completion of purchase arrangements takes valuable time when response to an event may require immediate action. To address this problem, the NMFS Southeast Fisheries Science Center created 20 kits (Table 2) that were prepositioned in the Southeast to be used in unusual mortality events.

Although the list is not intended to be all-inclusive, it does convey examples of the types of equipment that may be needed. Such kits may vary depending on the Region, species, and equipment normally available. Among suggestions for additional equipment that have been made are flensing knives and blue ice for cooling. A similar list of equipment drawn from numerous protocols is contained in the field guide prepared for Stranding Network members (Pages 287-289 in Geraci and Lounsbury, 1993).

Each NMFS and FWS Regional Office should consider following the example of the Southeast Fisheries Science Center and purchase equipment that may be needed in advance. At a minimum, the Regional Offices should identify sources where equipment can be obtained and develop streamlined procedures for its rapid deployment in the field. The equipment should be appropriate for a variety of tasks covering the range of information that might be needed to determine the cause of a mortality event. 
TABLE 2

SOUTHEAST STRANDING KIT INVENTORY

100 quart cooler

2 large sharp knives

long-handled pruners

large bow saw

knife sharpener/stone

plastic scalpel handles (2)

box of surgical blades

titanium knife

vacutainer holders (5)

sterile vacutainers

(20 EDTA $5 \mathrm{cc}$ )

(20 plain $10 \mathrm{cc})$

(20 heparin $10 \mathrm{cc}$ )

(20 serum-separator)

vacutainer needles

(30@ 20 ga.x1-1/2)

syringes (sterile)

(10@5cc)

$(10 @ 10 \mathrm{cc})$

(10@ 20 or $30 \mathrm{cc})$

(10@50 or $60 \mathrm{cc}$ )

needles (sterile)

(10@ 18 ga.x1-1/2)

(10@ 22 ga.x1)

(1@ 14 or 15ga.x3-1/2)

(5@18 ga.x3-1/2)

vacutainer needle disposer

butterfly $19 \times 7 / 8,12$ " tubing

infusion set (10) metric ruler

flashlight

size $\mathrm{D}$ batteries

$30 \mathrm{~m}$ fiberglass tape measure

heavy rope

2 short meat hooks

16 " selecting hook

12 "x12" plastic ziploc bags

6" 66 " plastic ziploc bags

aluminum foil

blank polypaper labels

permanent markers

large heavy duty plastic bags

heavy rubber gloves ( $2 \mathrm{pr}$.)

powder-free latex gloves

surgical masks

disposable cover-alls (4)

surgical scissors

$500 \mathrm{ml}$ teflon bottles (2)

glass jars, formalin samples (12)

buffered $10 \%$ formalin (4L)

pre-soaked alcohol wipes

spool of twist ties

10 " teflon-coated tongs

titanium forceps

teflon forceps

teflon bags (6"x8")

polyfoam container for blood shipment

\section{Protocols and Training}

The availability of equipment does not ensure that necropsies will be properly performed or that high quality tissue samples will be collected for analysis. To accomplish this task, detailed protocols and training are needed. Three such protocols have been developed for distribution to Stranding Network members. The stranding field guide (Geraci and Lounsbury, 1993) was distributed to NMFS Stranding Network members in 1993. The guide contains basic protocols for necropsies and collection and preservation of tissues for a variety of analyses. The guide covers cetaceans, pinnipeds, manatees, and sea otters. NMFS has also prepared and distributed more detailed laboratory manuals to be used for cetaceans (Galloway and Ahlquist, in press) and pinnipeds (Dierauf, 1994). FWS also has prepared a manual on necropsy of manatees (Bonde et al., 1983). These guides contain information on how to perform necropsies and how to collect and preserve tissues for: histopathology; life history; bacteriology; virology; mycology; 
parasitology; biotoxins; contaminants; and genetics. The manuals also contain chain of custody instructions. Although not a formal part of this contingency plan, these protocols are incorporated by reference. It is recommended that these guides be kept together at each Stranding Network facility and that Network members should incorporate these documents into their curricula and training courses for personnel who might be involved in a response to an unusual mortality event.

To avoid delays and improper collection and preparation of tissues, another part of preplanning activities should be training of individuals who are likely to be participants in a response to an unusual mortality event. Using the protocols, training should be given in gross necropsy procedures and the collection and preparation of samples for the range of analyses discussed in the section below entitled "Necropsy, Tissue Collection, Preservation, and Analyses." Two other topics should be presented in training sessions: following chain of custody procedures and a review of safety procedures.

\section{Compilation of Lists}

This contingency plan contains lists of organizations and people to be notified when an unusual mortality event occurs. Stranding Network members are listed in Addendum A. (Because lists containing information such as Stranding Network membership and individuals who can perform necropsies are likely to be subject to change, they have been incorporated as addenda rather than appendices so that they can be changed without amending the entire document). Depending on the Region involved, NMFS and FWS representatives have telephone numbers, FAX numbers, and, in some instances, the capacity to communicate via e-mail with each Stranding Network member within their Regions. A list of Federal agencies with jurisdiction over beach areas is contained in Addendum B. There are eight Coast Guard Districts in marine areas. These are:

First Coast Guard District (ME, NH, MA, CT, RI, NY)

Coast Guard Building

408 Atlantic Ave.

Boston, MA 02110-3350

(617) 223-8480

Fifth Coast Guard District (NJ, DE, MD, VA, NC)

Federal Building

431 Crawford St.

Portsmouth, VA 23704-5004

(804) $398-6000$

Seventh Coast Guard District (SC, GA, Peninsular FL)

909 SE First Ave.

Brickell Plaza Federal Bldg.

Miami, FL 33131-3050

(305) $536-5683$

Eighth Coast Guard District (FL Panhandle, AL, MS, LA, TX) 
Hale Boggs Federal Bldg.

501 Magazine St.

New Orleans, LA 70130-3396

(504) 589-6230

Eleventh Coast Guard District (CA)

501 West Ocean, Suite 7170

Long Beach, CA 90822-5399

(310) $980-4300$

Thirteenth Coast Guard District (OR, WA)

Jackson Federal Bldg.

915 Second Ave.

Seattle, WA 98174-1067

Fourteenth Coast Guard District (HI)

Prince Kalanianaole Federal Bldg.

300 Ala Moana Blvd., 9th Floor

Honolulu, HI 96850-4982

(808) 541-2260

Seventeenth Coast Guard District (AK)

P.O. Box 25517

Juneau, AK 99802-5517

(907) $586-7298$

Although the Coast Guard Operations Manual has instructions to report stranded marine mammals, and some units/stations are included on the list of Stranding Network members, the appropriate District Headquarters should be notified when there is an unusual mortality event. Upon receipt of reports of stranded animals, the Coast Guard will contact the appropriate Network representatives and provide the information needed for response. Operations permitting, they may also be available to assist in salvage, rescue, or disposal of animals, as well as for providing security or other assistance.

Addendum $\mathrm{C}$ contains a list of State agencies with jurisdiction over natural resources as contact points for State governments. Addendum D lists State public health agencies to be contacted should there be concern that a mortality event might affect human public health. Addendum E lists Native American organizations to be contacted if a mortality event occurs in either the Pacific northwest or Alaska.

\section{Early Monitoring Activities}

There may be a period of time between an initial observation that marine mammal mortalities are increasing and the determination that a full-fledged mortality event is in progress. In some cases, the actions taken during this period ultimately may determine the success of a subsequent investigation into the cause(s) of a mortality event. 
When there is reason to believe that there may be an incipient mortality event, the agency with jurisdiction over the species should take steps to ensure that strandings are reported on a real-time basis so that numbers of mortalities can be closely monitored. An effort should be made to ensure that experienced specialists perform gross necropsies on all carcasses.

In some mortality events, early collection and preservation of samples for later analysis may be critical. For example, if a mortality event is precipitated by a toxic discharge, water sampling two or three weeks after the discharge may not detect the toxic compound. In order to enhance the potential of finding the cause of a mortality event, an effort should be made during the monitoring phase to collect and preserve samples that could be used later for diagnosis. If mortalities are localized, water samples should be collected. Sets of tissues appropriate for a range of analyses should be collected. Depending on the type of anticipated analysis, some tissues may be fixed in formalin, and some may be frozen. If available, blood serum from fresh carcasses and affected live animals should be collected and frozen.

Because early monitoring activities will take place before the appointment of an Onsite Coordinator, each NMFS and FWS Region should prepare a basic protocol appropriate for its species and available resources to be used during this period. 


\section{INITIAL STEPS}

The Marine Mammal Health and Stranding Response Act sets up an initial procedure to be followed if an unusual mortality event is suspected. Members of the Working Group on Unusual Marine Mammal Mortalities are to be consulted to determine if a mortality event actually is occurring.

\section{Criteria for Determining Unusual Mortality Event}

The Working Group has developed a set of criteria to be utilized in making this judgment. A single criterion or combination of criteria may indicate the occurrence of an unusual mortality event. The criteria are:

1) A marked increase in the magnitude of strandings when compared with prior records. There is no set formula for determining what magnitude would trigger a response. The NMFS Southeast Region has used a formula of the historic mean plus two times the standard deviation to determine a threshold level. The Working Group stated that magnitude must be weighed against other knowledge. As a pragmatic method, it was suggested that if a pulse in strandings is spread over an area or timeframe that strains the capacity of the Stranding Networks to respond, it should be cause for concern.

2) Animals are stranding at a time of the year when strandings are unusual.

3) An increase in strandings is occurring in a very localized area (possibly suggesting a localized problem), is occurring throughout the geographical range of the species/population, or spreads geographically with time.

4) The species, age, or sex composition of the stranded animals is different than that of animals that normally strand in the area at that time of the year.

5) Stranded animals exhibit similar or unusual pathologic findings or the general physical condition (e.g., blubber thickness) of stranded animals is different from what is normally seen.

6) Mortality is accompanied by behavior patterns observed among living individuals in the wild that are unusual, such as occurrence in habitats normally avoided or abnormal patterns of swimming and diving.

7) Critically endangered species are stranding. Stranding of three or four right whales, for example, may be cause for great concern whereas stranding of a similar number of fin whales may not.

\section{Appointment of Onsite Coordinator}

When the determination is made that an unusual mortality event is occurring, NMFS or FWS is responsible for appointing an Onsite Coordinator. The Onsite Coordinator is to be one 
or more of the appropriate Regional Directors of NMFS or FWS or their designees. The Onsite Coordinator is responsible for directing the response.

The Onsite Coordinator should have the background and knowledge needed to coordinate a scientific investigation. The Working Group on Unusual Marine Mammal Mortality listed the qualities/skills that the Onsite Coordinator should have:

1) Strong management and leadership abilities including the ability to coordinate a range of support services. The Onsite Coordinator will be responsible for implementing an event-specific plan. In addition, it will be necessary to consult and cooperate with agency headquarters, the Working Group, and other appropriate individuals;

2) Strong communications skills. The Onsite Coordinator will be the primary contact for members of the Working Group and the primary recipient of daily information and reports. (S)he should be diplomatic and calm when working with individuals in a crisis situation;

3) The ability to make decisions with minimal use of intermediaries;

4) The ability to access information and expertise including interagency expertise (e.g., NMFS, FWS, Environmental Protection Agency, U.S. Department of Agriculture, National Biological Service), scientific contacts, and logistical contacts;

5) Familiarity with this contingency plan and associated protocols; and

6) Familiarity with and ability to work with the Marine Mammal Stranding Networks.

\section{Notifications to Accelerate Response}

In all mortality events, it is important to accelerate the response, and there are a number of notifications that should take place under the direction of the Onsite Coordinator:

1) Stranding Network members (Addendum A) should be notified that a response to an unusual mortality event has been initiated and that they will be acting under the direction of the Onsite Ccordinator. They should be given specific instructions as to steps to be taken in the response.

2) Federal beachfront agencies (Addendum B) should be alerted and provided with instructions as to whom to contact if an animal should strand on their beaches. As in the case of State Wildlife Resource Agencies, it should be determined if such agencies have additional resources, e.g., biological personnel, boats, etc. that can supplement the response.

3) State Wildlife Resource Agencies (Addendum C) should be contacted to alert them to the mortality event and to determine if they can provide resources to assist in responding. The Onsite Coordinator should obtain the names and telephone numbers of field 
supervisors in the area who could be contacted for various types of assistance, e.g., biologists, boats and operators, law enforcement personnel.

4) Coast Guard District Headquarters should be alerted and given instructions as to who should be contacted if they observe a stranded animal. They should be notified if a formal enforcement case is likely because the Coast Guard provides joint support to the responsible agencies in law enforcement/fisheries related cases.

5) Potential public health problems may be present during a mortality event. In many instances notification of the appropriate local authorities will be necessary for assistance in restricting access to live animals and rotting carcasses and to ensure that carcasses are disposed of properly. If a serious health hazard, e.g., a serious disease transmissible to humans, is identified, the State Public Health Department should be contacted. In some instances it may be necessary to notify the Centers for Disease Control in Atlanta. The Onsite Coordinator is responsible for reducing safety risks to those working in the field whether those risks are exposure to the animals themselves, to pathogens, or to contaminants.

6) In many areas, local governments serve as the conduit for information on initial reports of stranded animals. In the Northeast, the NMFS Regional Office has prepared a list of all local government police forces. Similarly, local governments have played a major role in areas such as California. Contacts with local agencies that may receive reports of strandings will help to accelerate the response.

7) The FWS (or supporting National Biological Service Science Centers) and NMFS have Regional Laboratories that can provide specific services such as tissue collection, processing, and analyses for toxins and disease-causing agents. Such laboratories should be involved in both advance planning and response.

8) In the Pacific northwest and Alaska, Native American groups are actively involved in marine mammal management, and, in some areas, are dependent on marine mammals for subsistence harvest. In addition, permission from tribal authorities may be necessary to enter specific coastal areas. If a mortality event occurs in such areas, tribal governments or management units such as the Eskimo Walrus Commission should be notified. A list of these groups is included in Addendum E. In addition, an effort should be made to involve Native Americans in the response.

\section{Assessment of Capacities, Capabilities}

When live animals are involved, an Onsite Coordinator must make provision for care or, if appropriate, euthanasia of such animals. Among the first actions should be an effort to determine what capacity is currently available in those facilities authorized to rehabilitate stranded animals. If capacity is insufficient, the Coordinator should either make arrangements for expanding capacity or locate backup facilities. In instances when the unusual mortality event is characterized by large numbers of dead animals, the primary foci of activity should be 
expeditious recovery and examination of carcasses, complete necropsy of the freshest animals, collection of tissues for relevant analyses, and proper handling and disposal of carcasses.

The response for an event of known cause is likely to be directed primarily toward treatment of affected animals, documentation of specific effects on animals, and, if feasible, intervention to prevent additional mortalities. The Onsite Coordinator should make provision for rescuing live animals and recovering carcasses. Provisions should be made to rehabilitate what may be large numbers of animals under conditions that prevent the spread of pathogens to healthy animals and to prevent animals being rehabilitated from being infected with pathogens from other sources. Possible pathways for infection include not only animals of the same species but humans, domestic animals, and other wild terrestrial and aquatic animals. After consultation with the Working Group, the Onsite Coordinator will be responsible for communicating to facilities any medical tests to be performed and any special provisions for care.

When appropriate, instructions should be provided on tissue collection and chain of custody protocols if legal action is possible. When all other provisions are in place, plans may be made for collecting tissues for opportunistic research.

When the reason for a mortality event is unknown, the primary task will be to identify the cause(s). The Onsite Coordinator must make arrangements for collection, preservation, and storage of tissues until an investigative plan is developed covering all possible causes. Assistance from a variety of specialists may be necessary. An effort must be made to step up the response including carcass recovery so that tissues may be collected in a timely fashion. The condition of a carcass often deteriorates rapidly limiting its suitability for analyses. Therefore, expeditious response is particularly important. The Coordinator must also ensure that necropsies are performed and tissues are collected for analyses following prescribed protocols. Provisions must be made for proper preservation and shipment of tissues to researchers using proper chain of custody procedures.

The Onsite Coordinator will have to determine whether existing human and material resources in the area are adequate. In some areas, the Stranding Networks may be able to provide an adequate response and collect tissues for analysis. There are at least three instances when existing coverage may have to be supplemented: (1) There may be a geographic gap in Network coverage in the area; (2) The magnitude of an event may be such that it is beyond the capacity of the Network to cover effectively; and (3) The necropsy/tissue collection requirements may be beyond the expertise and/or resources of some Network members.

If local resources are inadequate, a response team incorporating the necessary levels of expertise should be mobilized. In specific Regions, such teams may be constituted from NMFS or National Biological Service laboratory personnel. The NMFS Southeast Region developed such a team in responding to the mortality event in Texas in 1992. Similar capacity also exists in NMFS Northwest Region if personnel from the National Marine Mammal Laboratory are used. The National Biological Service's National Wildlife Health Center in Madison, Wisconsin, serves a similar role for species under Interior jurisdiction.

Particularly in the case of cetaceans, the material with which investigators work is likely to be of less than ideal quality. Often, the only carcasses available are those that have washed in and are in varying stages of autolysis. Table 3 adapted from the cetacean laboratory forensic manual shows analyses that can be conducted by condition of a carcass. 
TABLE 3.

Guide To Data and Sample Collection for Condition Code 1-5 Marine Mammals

Sample Type

\section{Clinical}

Respiration rate

Heart rate

Urine sample

Blood sample

\section{Life History}

Stomach \& contents

Jawbone/teeth

Skull

Rib/spinal section

Morphometrics

Reproductive organs

Parasites

Blubber thickness

\section{Genetics}

\section{Parasitology}

Microbiology

\section{Toxicology}

\section{Histopathology}

\section{Necropsy}

External observations

Site observations

Ectoparasites

Gross lesions

Gross dissection

Parasites

Gross lesions

Organs

$\begin{array}{lllll}1^{1} & 2^{2} & 3^{3,4} & 4^{3} & 5\end{array}$

\section{CONDITION CODE}

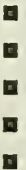

a

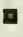

a

a

-

-

घ

a

-

-

-

$\square$
$\square$
$\square$
$\square$
$\square$

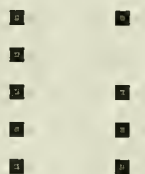

a

-

-

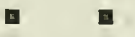

a

a

घ

1. Code 1 animals are reassigned to Code 2 at death.

2. Heart blood collected shortly after death.

3. Morphometrics should be taken on late Code 3 and Code 4 animals only for those measurements that are not altered by decomposition of the soft tissues.

4. Some tissues degrade quickly and will not yield samples suitable for histopathology; judgement is required. 
The condition codes are:

Code 1--Live animal

Code 2--Dead, extremely fresh, no bloating, organs fresh

Code 3--Early--minor bloating, skin peeling, organs intact Late--moderate decomposition, bloating, skin peeling

Code 4--Advanced decomposition, bone exposed, major bloating skin peeling, internal organs decomposed

Code 5--Mummified or skeletal remains, no organs present

The number of analyses that can be conducted decreases rapidly as a carcass deteriorates. It is, therefore, imperative that an effort be made to recover carcasses quickly.

\section{Aerial Surveys}

Because beaches in some areas may be remote or only have limited beach traffic, aerial surveys may help in the detection of carcasses. Such surveys also can provide initial information on the magnitude of an event. The Onsite Coordinator should consider such surveys when an event is occurring in a low traffic area. Among the resources that may be available are NOAA or Coast Guard airplanes and helicopters. The Onsite Coordinator should be aware that while such agencies provide assistance when possible, their primary mission does not include such aerial overflights, and search and rescue operations always take priority. To determine if they can provide assistance, the Onsite Coordinator should contact the appropriate Coast Guard District Headquarters listed above or the NOAA Aircraft Operations Center at (813) 830-3310. If the Onsite Coordinator is unable to use official aircraft, it may be possible to contract for private aircraft or utilize offers from private organizations. Aerial surveys can also provide information on whether carcasses are being reported in a timely fashion in areas where coverage is assumed to be adequate.

The Onsite Coordinator also will be responsible for determining what additional equipment may be needed. Such equipment may range from transportation equipment to make sure that both live animals and carcasses are rapidly retrieved to the equipment necessary to collect tissue samples for analysis. In the past, when existing transportation equipment has not been adequate, trucks have been rented. Because response to an unusual mortality event entails collection of materials beyond the minimum information requirements of normal strandings, respondents may need additional equipment to collect and preserve tissues. As noted above, it is recommended that such equipment be purchased in advance and prepositioned. Whether such a step is taken or not, the Onsite Coordinator will be responsible for provision of equipment when needed. 


\section{Environmental Parameters}

When the cause of a mortality event is unknown, possible environmental factors that could account for an increase in strandings should be evaluated. It is possible that an increase may be an artifact of changes in current or wind patterns resulting in a higher percentage of carcasses being washed ashore than would normally be the case.

To check on current anomalies, the Coordinator may contact:

NMFS Monterey Laboratory at (408) 656-3311.

Changes in the water temperature may also have an impact on certain species of marine mammals. As an example, in January 1990, over 30 bottlenose dolphins were found dead in Matagorda Bay, Texas, following a cold snap during which ice formed on the Bay (Miller, 1993).

To obtain real time information on sea surface temperatures, the Coordinator may contact the Coast Watch Program of the National Environmental Satellite, Data, and Information Service at (301) 713-3277.

If there are reports of unusual deaths of other animal species such as fish or birds or if the mortality is extremely localized, there is the possibility that a toxic event might be responsible. When initial contacts are made with State wildlife agencies and Federal beachfront agencies, inquiries should be made to determine if they have observed increased mortality of other species. In such instances the Onsite Coordinator will take steps to determine if a toxic phytoplankton bloom has occurred in the vicinity of the mortality event.

The Onsite Coordinator should check with the shellfish monitoring program to determine if there have been shellfish bed closures. Information on shellfish monitoring can be obtained from the State resources agencies that have responsibility for shellfish monitoring in each State.

The Office of the Executive Director of the Interstate Shellfish Sanitation Conference, (803) 788-7559, can provide points of contact within each State.

The Onsite Coordinator also may contact the Marine Biotoxins Program at the NMFS Charleston Laboratory, (803) 762-8529, to initiate investigations into the potential role of a toxic phytoplankton bloom.

The Marine Biotoxins Program has analytical capabilities for rapid response to suspected toxic blooms and has established a network with regional experts and State regulatory agencies to coordinate sample collection, phytoplankton identification, and toxin analysis. Instructions for tissue collection for biotoxin analysis are given below.

It should be noted that biotoxins can pose a human health hazard. They have been responsible for paralytic shellfish poisoning, amnesic shellfish poisoning, and ciguatera poisoning. If there is evidence that such agents may be responsible for a mortality event, seafood safety perscnnel should be contacted immediately.

Indicators of a direct toxic event caused by anthropogenic contaminants are similar to those for biotoxins. If it is suspected that chemicals in the water may be contributing to a 
mortality event, the Coordinator should contact the nearest Regional Office of the Environmental Protection Agency to make arrangements for an initial investigation including water sampling.

EPA Region 1 (ME, NH, MA, CT, RI)

Water Management Division

John F. Kennedy Federal Building

One Congress Street

Boston, MA 02203

(617) $565-3420$

EPA Region 2 (NY, NJ, PR, VI)

Water Management Division

Jacob K. Javits Federal Building

26 Federal Plaza

New York, NY 10278

(212) 264-2513

EPA Region 3 (DE, MD, VA)

Water Management Division

841 Chestnut Building

Philadelphia, PA 19107

(215) 597-9410

EPA Region 4 (NC, SC, GA, FL, AL, MS)

Water Management Division

345 Courtland Street, N.E.

Atlanta, GA 30365

(404) $347-4450$

EPA Region 6 (LA, TX)

Water Management Division

First Interstate Bank Tower at Fountain Place

1445 Ross Avenue, Suite 1200

Dallas, TX 75202-2733

(214) 655-7101

EPA Region 9 (CA, HI, GU)

Water Management Division

75 Hawthorne Street

San Francisco, CA 94105

(415) 744-2125 
EPA Region 10 (OR, WA, AK)

Water Division

1200 Sixth Avenue

Seattle, WA 98101

(206) 553-1233

In the Southeast Region, the NMFS Laboratory in Charleston, (803) 762-8500, has also conducted water quality analyses. In addition to water quality analyses, it may be necessary to analyze sediments and indigenous fish and invertebrates for the presence of anthropogenic contaminants.

\section{Data Requirements}

The Onsite Coordinator also will be responsible for taking such action as will be necessary to determine the impact of a mortality event on the marine mammal population(s) affected. In order to accomplish this task, it will be necessary to compile data on the number of marine mammals affected. In addition, information on the geographic extent of the mortality and factors in population dynamics such as age and sex of animals affected should be collected. Much of this information may be gathered from stranding report forms, but arrangements to compile the information should be made.

If the mortality event is large-scale in relation to the size of the specific population(s) affected, it may be necessary to conduct surveys to determine the impact. Strandings may provide an indication of the magnitude of an event, but they only account for animals that reach shore. To determine the geographic extent of a mortality event, offshore survey work may be necessary. It also may be necessary to prepare abundance estimates for comparison with preevent population estimates. 


\section{ADMINISTRATIVE TASKS}

In addition to conducting the investigation, there are a variety of administrative tasks involved in responding to a large-scale unusual mortality event. In past events, NMFS has learned that administrative activities can have an impact on the response to an event. When equipment cannot be ordered in a timely fashion, samples are not carefully tracked, or requests for information impinge on investigative time, the failure to address administrative issues adequately can hinder an investigation. At best, it is difficult to handle both the research tasks and the administrative tasks; at worst, attempting to handle both simultaneously may mean that neither is adequately addressed. A separate team should be set up to work with the Onsite Coordinator on administrative tasks. The size of the team will vary depending on the magnitude of the event, but provision should be made for financial coordination, public information coordination, and tracking of animals and samples. The administrative team must work closely with the Onsite Coordinator in order to meet the needs of the investigation.

\section{Financial Administration}

As indicated above, the Act creates a Marine Mammal Unusual Mortality Event Fund to cover the "special" costs incurred in responding to such events. Upon designation of an unusual mortality event the Assistant Administrator for Fisheries may release funds for response. The Onsite Coordinator will determine which expenses will be eligible for reimbursement. The Fund may be used to reimbuse costs not normally part of operating expenses. For example, if it should be necessary to dispatch a response team to the site of a mortality event, the costs incurred other than usual salary expenses could be covered. In addition, once the Onsite Coordinator designates facilities for analyses, contracts for reimbursement will be set up.

The Act also provides that Stranding Network participants shall be reimbursed for costs incurred in the preparation of tissues and shipment of tissues. Such costs may include equipment that must be purchased. The House Report accompanying the bill stated that such reimbursement would be limited to costs beyond normal stranding response. Stranding Network members will not be reimbursed for time, gasoline expenses for response, or for carcass disposal. The House Report details the procedures for reimbursement. The Stranding Network participant must receive authorization from the Onsite Coordinator to incur such expenses, save the receipts, and file a claim for reimbursement. If there are insufficient amounts available in the Fund to satisfy pending claims, they will remain pending until such time as sufficient funds are available. All authorized pending claims will be satisfied in the order received.

Upon release of funds from the contingency fund or after other financial provisions are made, a financial officer will be appointed by the appropriate Regional Office to work with the Onsite Coordinator. The financial officer shall be a certified Contracting Officer's Technical Representative and will work with a certified Contracting Officer to:

1) Negotiate and enter into agreements for reimbursement for services performed in the course of a response to an unusual mortality event. Whenever possible, such agreements should be in writing and describe exactly what services will be performed and what the rate of reimbursement shall be. As an example, it should be determined in advance what types of expenses will be reimbursed for care and rehabilitation of live animals. Contracts will include language stating that disclosure of results without clearance from 
the Onsite Coordinator is prohibited. It is also recommended that an initial ceiling level be determined on individual contracts. Without such a ceiling, it may be difficult to control costs. If the ceiling level is reached, an opportunity for reassessment is available.

2) If requested by the Onsite Coordinator, be responsible for locating and ordering supplies and equipment as they are needed.

3) Be responsible for prompt payment for contracted services, purchase orders, and reimbursement for expenses such as travel.

\section{Public Information}

Whenever an unusual mortality event occurs, it should be anticipated that there will be public concern and inquiries. It should be emphasized that public interest is legitimate and that the agencies have a responsibility to convey accurate information in a timely manner. Accurate information can help to educate the public and may help in accelerating a response. Speculation and/or inaccurate information may raise undue alarm and do more harm than good, including damaging potential legal aspects of an investigation.

There are two types of situations that should be anticipated: (1) an on-the-beach situation involving interested bystanders and/or (2) media and general public inquiries during the course of an investigation.

The first situation is most likely to occur during mass stranding events, but is also possible during ongoing events. In order to prevent interference with rescue operations and other activities, it is recommended that, when possible (or necessary), an onsite spokesperson be designated. This person should be knowledgeable and able to provide basic information on the species involved, the procedures being undertaken, and operation of Stranding Networks.

Participants in the response to unusual mortality events should be encouraged not to speculate on causes and not to attempt to answer questions beyond their level of knowledge. If an individual does not know the answer to a question, it is acceptable to answer, "I don't know." Even better, take the individual's name and telephone number and promise to get back to them with an answer. The NMFS Office of Public Affairs, (301) 713-2370, or the FWS State or Regional Office, will make an effort to find the answer to specific questions and get back to an individual.

It should be anticipated that there will be media inquiries during the investigation of an unusual mortality event. To the extent feasible, an effort should be made to funnel requests for information to a single individual. That individual may be a public affairs officer designated by the agency or an individual involved in the response. Participants in the response should receive a telephone number where the designated media contact can be reached and should be encouraged to refer inquiries to that individual. The designated media contact should be briefed regularly by the Onsite Coordinator as to progress in the investigation. The media contact should immediately contact local media if there is a public health concern. Whenever working with local media, the media contact should emphasize the importance of a rapid response and emphasize that the general public can provide assistance by reporting strandings as soon as possible.

The media contact should make every effort to be helpful to the media but should avoid speculation as to the cause(s) of an event. Because they can be misleading, partial results of the investigation should not be disclosed without clearance from the Onsite Coordinator. Instead, it 
may be worthwhile to discuss the types of analyses being conducted and, using examples of past mortality events, to explain why specific analyses are being conducted. The media contact should not disclose the names of specific researchers involved. During past mortality events, individual researchers have expressed frustration that interruptions from the media have made their task more difficult. If technical questions are received, the media contact may communicate with a researcher in order to answer a media inquiry if such a course of action is recommended by the Onsite Coordinator. In some cases with the approval of the Onsite Coordinator, technical inquiries may be referred to individuals involved in the investigation.

The designated media contact should keep a list of inquiries so that follow-up calls can be made when significant findings occur or when an event is determined to be over.

\section{Tracking of Animals and Samples}

It may be necessary to appoint an individual specifically dedicated to tracking live animals and samples. As indicated above, multiple samples may be taken from a single animal and sent to different facilities for analysis. It is important that all analyses from an individual marine mammal be accessible if the goal is to obtain a total picture of an animal's health. All shipments, analyses, and results should be collected in a central data base with all information on an individual animal accessible under a single unique number. Photocopies of all stranding reports, gross necropsies, shipments of tissues, and analytical results should be sent to a central location designated by the Onsite Coordinator for data entry.

Arrangements also should be made to retain voucher specimens, i.e., photographs and skulls. To avoid confusion, the master file should have a single number for all materials from a single animal even if those receiving tissues may assign their own accession number. It is recommended that this number be the field number assigned by the individual who initially collects the animal. When there is a possibility of litigation, special care must be taken to keep a record of the movement of samples, and the protocol for chain of custody should be strictly observed. Arrangements should be made with those participating in the response to provide duplicates of stranding reports and all transmittal forms to the individual responsible for tracking. In addition, copies should be made of all correspondence, analytical results/reports, notes, data sheets, and any other documentation. These copies should be placed in a secure location so that there is complete documentation of the investigation.

In order to facilitate movement of tissues for analysis, the individual responsible for tracking should make arrangements for overnight shipment. This can either be done by furnishing preprinted forms or an account number to participants in the response.

Just as written records of analyses are important, permanently archiving duplicate sets of tissues may assist future investigators. Upon the recommendation of the Onsite Coordinator, the individual responsible for tracking should make arrangements for such archival. Permanent archival may entail making arrangements for formalin-fixed tissues, frozen tissues, and osseous materials. Archival arrangements should be made with institutions rather than with individuals. The Armed Forces Institute of Pathology (202) 782-2600 has indicated a willingness to be a repository for pathology tissue samples. Various museums and institutional members of the Stranding Network maintain collections of skulls and life history materials. As examples, the Smithsonian Institution, Natural History Museum of Los Angeles County, University of Washington Burke Museum, Texas A\&M University, and Sea World of Florida all maintain collections of materials from cetaceans. The New England Aquarium has maintained a collection 
containing both cetaceans and east coast pinnipeds. The University of Alaska-Fairbanks Museum archives materials from Alaskan marine mammals. Various NMFS laboratories have limited capacity for storage of formalin fixed and frozen tissues. A permanent record of archived materials should be maintained and combined with the records of tissues shipped for analysis. 


\section{LIVE ANIMALS}

The initial decision involving live stranded animals takes place on the beach. An expert assessment of an animal's condition is necessary before making a decision to take an animal in for rehabilitation, to euthanize it, or to treat it and release it on site. With the exception of mass strandings, the third of these options will be inappropriate in most instances. Such decisions shall only be made by competent professionals.

\section{Available Facilities and Requirements}

A list of facilities with experience in treating stranded marine mammals is included as Addendum $F$. The procedures in this contingency plan are predicated on the assumption that those with previous experience in treating marine mammals are most competent to treat live animals. Nevertheless, such facilities and their veterinarians should make an effort to maintain up to date references on diagnosis and treatment of marine mammal diseases. In addition to the protocol manuals mentioned above, an extremely detailed protocol on care and rehabilitation of sea otters has been prepared (Williams and Davis, 1995). Although designed for response to oil spills, much of the information is applicable to other types of mortality events and to other species of marine mammals. Materials such as the Handbook on Marine Mammal Medicine (Dierauf, 1990) also are useful. The Working Group may prescribe appropriate event-specific treatment measures.

Precautions should be taken to ensure that animals being treated are quarantined from healthy captive animals and that personnel take measures to avoid cross-contamination within the facility.

Although some facilities can accommodate relatively large numbers of pinnipeds and/or sea otters, the physical facility requirements for maintenance of cetaceans are such that only limited numbers of small cetaceans can be treated during a mortality event. Cetaceans and manatees require, at a minimum, pools large enough to accommodate them. Pools should be on a separate water system so that disease cannot be spread to healthy animals within the facility. In the case of an emergency, sea otters and pinnipeds are not totally dependent on pools, and in past epizootics such as the leptospirosis outbreak in 1984, pinnipeds have been accommodated in dry areas with access to fresh drinking water and saltwater baths. Even in such circumstances facilities must have the ability to isolate animals from display animals and terrestrial animals that may either transmit or be exposed to pathogens. The facilities that are authorized to provide treatment for marine mammals and have veterinary services (except for those designated as shortterm) are listed in Addendum $\mathrm{F}$.

This list has been provided to the agencies responsible for developing oil spill contingency plans. The Northeast, California, Washington, Oregon, and Alaska have provisions in oil spill contingency plans for involving Stranding Network members in the recovery of carcasses and the rescue and rehabilitation of live animals. In Florida, provisions are in place for manatees, but no arrangements have been made for cetaceans in any of the southeastern states.

Each facility listed in Addendum $\mathrm{F}$ has resources for activities such as live animal retrieval, medical diagnostic analyses, and food and pharmaceutical provisions. The costs of such services in an unusual mortality event may be beyond normal operating costs, however, and may create a financial burden. Arrangements for partial reimbursement for special costs should be specifically defined and implemented early in the response. 
It should be recognized, however, that even under the best of circumstances, a facility's physical capacity for treatment of live animals is limited. In the case of cetaceans, few facilities can manage more than an animal or two at a time. The 1992-93 El Niño event demonstrated that, even in the case of pinnipeds, facilities can be filled to capacity in a relatively short time. Therefore, attention should be given to methods by which capacity can be expanded in the event of an epizootic. In the case of cetaceans, live stranded animals have occasionally been accommodated in open ocean net pens. Purchase of materials for construction of such pens in advance will expedite expansion of capacity during an unusual mortality event. In the case of pinnipeds, manatees, and sea otters, advance procurement of materials for temporary pools and fencing will help expand capacity.

\section{Release Conditions}

To safeguard wild populations of marine mammals, no rehabilitated animals will be released that do not meet the guidelines for release of rehabilitated animals under $\S 402$ (b) of the MMPA. In addition, the Working Group will be consulted to determine if there should be eventspecific release standards. The release standards should give priority to the health of the wild population over the health of an individual animal. Provision should be made to monitor at least a representative subset of released animals to determine if they survive and resume being functional components of the affected population. 


\section{NECROPSY, TISSUE COLLECTION, PRESERVATION, AND ANALYSES}

The Onsite Coordinator will be responsible for setting up procedures for necropsy and collection of tissues for analysis. The tissues to be collected and analyses to be performed shall be determined in consultation with the Working Group. The Onsite Coordinator will be responsible for communicating procedures for tissue collection, preservation, and shipment to those involved in responding to strandings.

Tissue samples should be obtained from selected animals during a mortality event in order to: (1) confirm the cause(s) of death when a putative cause has been established from preliminary findings and history; (2) establish the cause(s) of mortality when the origin of the event is unknown; (3) establish the pattern and progression of lesions and other parameters; (4) establish baseline values for such things as contaminants; and (5) provide specimens to be archived for future studies of epizootics. Tissue samples constitute a valuable resource even for events when the etiology appears clear, e.g., environmental disturbance (El Niño, marked changes in water temperature), trauma, biotoxin, or fisheries interaction.

\section{Protocols and Available Trained Personnel}

As a necessary first step, complete necropsies should be performed by trained personnel following the protocols contained in the manuals (pages 187-199 in Geraci and Lounsbury, 1993; pages 18-50 in Dierauf, 1994, and section 2.3.4 in Galloway and Ahlquist, in press. Also see Jefferson et al., (1994). Each Region has a list of those individuals with the training necessary to conduct necropsies and their locations. In most instances, these individuals will be able to perform gross necropsies and to collect and prepare tissues for analysis. In instances when an extreme health hazard may be present or the possibility of litigation requires rigorous chain-ofcustody procedures, the Onsite Coordinator may have to make special arrangements. Addendum G contains an initial list of Stranding Network members with the expertise necessary to conduct necropsies. The list should be updated periodically. In addition to those listed and agency personnel that might make up a response team, it may be possible to work with veterinary schools and local veterinarians if technical training is provided. A list of veterinary organizations and schools is contained in Addendum H. Regional Stranding Coordinators should contact veterinary schools in advance to determine if there is interest and the ability to perform such functions. As an additional resource, the American Veterinary Medical Association has an Emergency Preparedness unit (800-248-2862 x287).

\section{Sea Otter Provisions}

Procedures for sea otters differ from other species. Necropsies and analyses for California sea otters will be performed by the National Wildlife Health Center of the National Biological Service in Madison, Wisconsin. They have an ongoing program to determine the causes of southern sea otter mortality. Sea otter carcasses should not be altered in any way. Carcasses should be cooled (NOT FROZEN) by immersion in iced water and shipped in an insulated container cooled by blue ice.

For sea otter mortalities in Alaska, contact U.S. Fish and Wildlife Service, Marine Mammals Management, (907) 271-2348. 


\section{Sample Shipment and Tracking}

The Onsite Coordinator should make arrangements for shipment of preserved tissues for analysis. (S)he should determine whether the tissues are to be sent to a central location before shipment for analysis or sent directly to the facility performing a specific analysis. Although not covered by this contingency plan, it should be noted that in the event of a discharge of an anthropogenic contaminant, a resource trustee will be designated to store tissues prior to analysis so that a proper chain-of-custody protocol will be followed. Some analyses such as viral and bacterial analyses are time sensitive, and samples should be shipped directly to the facility performing the analysis. In other instances such as contaminant analysis, tissues do not have to be analyzed within hours and may be preserved at a common collection site. If there are special requirements such as an ultra-cold freezer, the Onsite Coordinator should make such arrangements. Shipping instructions and labels with overnight mail account numbers should be provided to those involved in the collection and preservation of tissues.

Although, as indicated under Administrative Tasks, another individual may actually be responsible for tracking tissues, it will be the responsibility of the Onsite Coordinator to see that this is accomplished. In certain cases such as shipment to the Armed Forces Institute of Pathology, a photocopy of the standard transmittal sheet may be sufficient. When such standard forms are not used, a record of the shipment, the individual animal, and the tissue(s) should be kept so that it is possible to trace results back to the specific marine mammal. It is important that a unique identification number be assigned to each animal and that all tissues from an animal have the same number. Analyses from a single animal may be performed by more than one facility. As an example, certain life history information such as age and reproductive status are required to complement analyses of anthropogenic contaminants. If there is the possibility that litigation may be involved, the chain-of-custody protocol contained in the laboratory manuals should be followed. Recognizing that individual members of Stranding Networks may not have specific items required for adequate chain of command/custody protocols, e.g., a locked freezer with limited access, it is recommended that the chain-of-cusiody protocol still be followed as closely as possible because it provides an accurate record of where tissues are stored and where tissues are sent.

\section{Specific Types of Analyses}

Although by no means exhaustive, the following list includes specific types of analyses that may be required and facilities that have been used in past. Page numbers corresponding to protocols in the previously mentioned manuals are listed.

\section{Blood from live marine mammals}

Hematology and serum chemistries can be used to determine if blood values are within normal ranges. Because blood values are used routinely to monitor the health of captive animals, many of the facilities involved in rehabilitation of marine mammals either have their own capacity to conduct such analyses or have made arrangements with clinical laboratories to conduct such analyses. Such analyses also can be conducted by veterinary clinical laboratories or even hospitals that treat humans. 
Serum can also be analyzed for the presence/absence of antibodies to specific pathogens. The laboratory needs to be told for which antibodies the serum is to be analyzed. Tests may be run for a specific pathogen or for a suite of pathogens. In the past, the Department of Agriculture's National Veterinary Services Laboratories in Ames, Iowa, (515) 239-8599, USDA's Foreign Animal Disease Diagnostic Laboratory at Plum Island, New York, (516) 323-2500, and Cornell University's Veterinary Diagnostic Laboratory have performed analyses for NMFS. A number of veterinary colleges and clinical laboratories may be able to perform the analyses. If feasible, frozen serum also should be archived for future research.

Geraci and Lounsbury, 1993, pp. 178-181, 200-201

Dierauf, 1994, pp. 4-10

\section{Histopathology}

Microscopic examination of tissues is an essential procedure in determination of cause of death and often provides evidence of infectious agents, toxicity or other changes such as immunosuppression. In some areas, there is a practice of freezing carcasses in order to preserve them until a necropsy can be performed at a more convenient time. Freezing of carcasses greatly reduces the usefulness of tissues for histopathology. If necessary, carcasses may be refrigerated (but not frozen) temporarily prior to necropsy. A complete set of tissues should be collected in accordance with the necropsy protocol being utilized. When possible, multiple sets of tissues should be collected from each organ. The tissues should be fixed in 10 percent buffered formalin. In the case of NMFS species, it is highly recommended that examination arrangements be made with the Armed Forces Institute of Pathology (202) 782-2600 through the NMFS National Stranding Coordinator (301) 713-2322.

Geraci and Lounsbury, 1993, pp. 186-187, 216-219

Dierauf, 1994, pp. 51-54

Galloway and Ahlquist, in press, section 2.3.3.3

Bonde et al., 1983, pp. 57-58

\section{Life history}

Although the size of cetaceans and pinnipeds can provide a rough estimate of age, teeth should be collected to determine ages in adult animals particularly if contaminant analysis is to be performed. For toothed cetaceans, contact Dr. Aleta Hohn in the NMFS Beaufort Laboratory (919) 728-3595 to make arrangements for reading of growth layer groups from teeth. Similarly, the National Marine Mammal Laboratory (206) 526-4045 can perform the same task for both pinnipeds and cetaceans. Sea otter teeth are read by the National Biological Service in San Simeon (805) 927-3893. For manatees, the Marine Mammal Pathobiology Laboratory of the Florida Department of Environmental Protection (813) 893-2904 uses the periotic bone for age determination. 
Stomach contents should be collected and frozen to identify prey species. Among those who have analyzed prey species from stomach contents are Nelio Barros of the Hubbs-Sea World Research Institute (407) 363-2664, James Craddock of Woods Hole Oceanographic Institute, and NMFS' National Marine Mammal Laboratory (206) 526-4045. Intact prey and slurry may also be required for biotoxin analyses or for analysis of ingested toxins such as organophosphate pesticides in instances when acute toxicity is suspected.

Reproductive tracts should be collected and preserved in formalin following the protocols mentioned above. For cetaceans, contact Dr. Aleta Hohn (301) 713-2322 or the National Marine Mammal Laboratory (206) 526-4045.

Geraci and Lounsbury, 1993, pp. 186-187, 199, 202-205

Dierauf, 1994, pp. 13-15, 66

Galloway and Ahlquist, in press, sections 2.3.4.4 and 2.3.5

Bonde et al., 1983, pp 58-59

For preparation of reproductive tracts, also see Akin et al., 1993.

\section{Biotoxins}

A number of biotoxins such as saxitoxin (Geraci et al., 1989 and De Gange and Vacca, 1989), brevetoxin (Geraci, 1989 and O'Shea et al., 1991), ciguatoxin (Gilmartin, 1987), and domoic acid could possibly be responsible for mortality events. If biotoxins are present, they are often preceded by an algal bloom and may be accompanied by mortality of other species. If discolored water (red or brown) is noted, whole water samples (100 ml.) should be collected for identification of the bloom organism. Samples should be fixed by the addition of Lugol's iodine or 5\% buffered formalin and stored at room temperature until shipment. If possible, 4-gallon whole water samples from discolored areas should be collected for analysis of the toxicity of phytoplankton and stored at room temperature until shipment. (Note that these samples must be shipped to an analytical laboratory within two days, or bloom organisms may die or be overgrown by other species).

Analysis of biotoxins in marine mammals may be complicated by matrix problems, depending on the tissue being analyzed and the condition of the carcass. Therefore, collection of prey and indicator organisms from the area of the stranding may be important. Filterfeeding shellfish (mussels, clams, and oysters) in the area may be good indicators of toxic blooms because they accumulate toxins rapidly and to high levels. In addition, standard analytical procedures are established for shellfish tissue. In order to collect an adequate sample, two dozen shellfish or enough to give $100 \mathrm{~g}$ wet weight of tissue should be collected. Whole shellfish samples may be stored refrigerated several days before shipment. Prey fish species should also be collected if possible. Fish should be stored frozen until shipment. Marine mammal tissues potentially suitable for biotoxin analysis include serum, whole blood, liver, whole prey from stomach contents, and stomach content slurries. All samples should be collected in polyethylene tubes (blood) or bags and stored frozen until shipment. Contact the Marine Biotoxins Program of the NMFS Charleston Laboratory, (803) 762-8529 for analytical assistance. 
Geraci and Lounsbury, 1993, pp. 205-211

Dierauf, 1994, pp. 59-60

Galloway and Ahlquist, in press, section 2.3.3.4

\section{Heavy metals/organic contaminants}

Tissues to be collected for heavy metal/organochlorine analysis include liver, kidney, and blubber. Brain tissue should be collected if direct mortality from organochlorine poisoning is suspected. The protocols set up for such collections are rigorous in order to avoid contamination. If the necessary equipment is not available, larger pieces of tissue should be collected that can be subsampled by the laboratory conducting the analysis. Tissues are to be frozen before shipment. For NMFS species, any laboratory performing contaminant analyses should participate in the Quality Assurance program set up in conjunction with the National Marine Mammal Tissue Bank. The Environmental Conservation Division of the Northwest Fisheries Science Center (206) 860-3330 and the Charleston Laboratory (803) 762-1200 have performed such analyses in the past. Research for FWS on contaminants has been performed by the Patuxent Wildlife Research Center of the National Biological Service (301) 497-5720.

Geraci and Lounsbury, 1993, pp. 205-211

Dierauf, 1994, pp. 60-63

Galloway and Ahlquist, in press, section 2.3.3.4

Bonde et al., 1983, pp. 59-60

\section{Virology/bacteriology/mycology}

Samples for such analyses can only be collected from live or recently dead marine mammals. The sampling protocols contained in the field guide and laboratory forensic manuals should be followed. Among possible sources for such analyses are the National Veterinary Services Laboratories of the Department of Agriculture (515) 239-8266, the American Type Culture Collection (301) 881-2600, the National Wildlife Health Center of the National Biological Service (608) 264-5411, the NMFS Charleston Laboratory (803) 762-1200, Dr. Mel Eklund of the Northwest Fisheries Science Center (206) 860-3380, and Dr. John Buck of Mote Marine Laboratory (813) 388-4441.

Geraci and Lounsbury, 1993, pp. 186-187, 211-216

Dierauf, 1994, pp. 54-55, 57-59

Galloway and Ahlquist, in press, section 2.3.3.5

Bonde et al., 1983, pp. 60-61

The list of analyses discussed here is general in nature. It may be necessary to collect additional tissues and perform additional analyses depending on the nature of the event. As an example, if there is a question as to whether an organophosphate or a carbamate pesticide compound may have been responsible for an acute mortality, it might be necessary to collect extremely fresh brain tissue or blood to test for acetylcholinesterase inhibition and stomach 
contents for residue analyses. In such instances, it may also be necessary to obtain blood from healthy animals to determine "normal" acetylcholinesterase activity. Additional analyses may be prescribed in consultation with the Working Group. For additional analyses, a specific tissue collection protocol should be prepared.

\section{Conditions on Disclosure of Results}

Without authorization from the Onsite Coordinator, individuals who are reimbursed for performing analyses as part of an investigation may not disclose results to outside parties. Disclosure of partial results may be misleading. Additionally, no facility may withhold information from the Onsite Coordinator. Such conditions should be included in any contracts issued in the course of a response to a mortality event. If an individual or facility is unwilling to abide by such conditions, the Onsite Coordinator will use another facility.

In the past, there sometimes has been a question as to the availability of research data because individual researchers have a proprietary interest in publishing their own results. Because a declared unusual marine mammal mortality event is an emergency situation, all results of research will be provided as soon as it is feasible to the Federal agency responsible for the response. Currently, Letters of Authorization provide that Stranding Network members must cooperate with NMFS. A refusal to provide information during a mortality event should be viewed as non-cooperation. While NMFS and FWS are sensitive to the desire of individual researchers to receive the credit for research that they have conducted, in an investigation of an unusual mortality event, timely receipt of information becomes paramount.

In order to protect the interests of individual researchers, it is the position of NMFS and FWS that partial results of an investigation shall not be released to the general public without compelling circumstances. Once an investigation has been completed, however, the investigative results may be subject to disclosure. 


\section{SPECIAL CIRCUMSTANCES}

This contingency plan is structured to anticipate common actions that can be undertaken with a degree of flexibility. However, in some mortality events, special circumstances may dictate additional actions. These include: an event when there may be litigation; an event when a live capture is recommended; and mass strandings.

\section{Possibility of Litigation}

If there is evidence that a mortality event may have been caused by human action such as an oil discharge, toxic chemical release, or pesticide runoff, it is possible that litigation may result. Even though other agencies have responsibility for mounting a response to known oil discharge or hazardous chemical release, there are instances when such events may not be obvious, and it is important to maintain an evidentiary record. An extremely localized event with a number of different species affected may indicate such a cause. If the Onsite Coordinator suspects that human action may be responsible, consultations should be undertaken with the NOAA Office of General Counsel or the Office of the Solicitor in the Department of the Interior.

\section{Live Capture}

There may be instances when the capture of live animals may be necessary to provide information that cannot be gained from stranded carcasses. Capture and sampling of live animals may provide baseline information with which to make comparisons. Blood serum samples can provide information on past disease exposure and help determine if a disease is enzootic in a particular population. Collection of information on bacteriology and virology from autolyzed tissues can be problematic. Sampling of orifices from live animals can provide materials to be analyzed for microbiology. Impression smears and fine needle aspirates of lesions can provide material for cytologic diagnosis. Biopsies can provide samples for microbiology, contaminant analysis, and histopathology.

Capture of moribund animals that are still capable of swimming may also help determine the etiology of a mortality event. In addition to observing the progression of the medical condition, medical diagnostic tests can be performed that might not be possible if dead animals are the only source of samples. If moribund animals die or are sacrificed, individuals performing gross necropsies or harvesting tissues may have high quality materials for analysis.

During past mortality events, there have been instances when emergency authorizations have been given to capture live animals. Such operations require special equipment and trained individuals. Capturing a free swimming dolphin or a pinniped hauled out on a rock is difficult and potentially dangerous.

When live capture recommendations were made during past dolphin mortality events, the need to obtain equipment and experienced personnel caused delay. In some areas, the responsible agencies have adequate resources for live capture operations. In the case of manatees, FWS has both the necessary equipment and personnel. As a result of the sea otter translocation project, FWS has both the personnel and equipment needed for the live capture of sea otters off the coast of California. The NMFS Southeast Science Center has personnel with experience, and much of the equipment required. In addition, Mote Marine Laboratory has personnel with experience and 
immediate access to the equipment required, and Texas A\&M University has personnel experienced in live cetacean capture. On the west coast, NMFS personnel have been involved with live capture of pinnipeds for collection of scientific information but have little experience with cetaceans. In Alaska, the Alaska Department of Fish and Game has live capture experience with pinnipeds and belugas (Delphinapterus leucas). The University of Alaska-Fairbanks and the North Slope Borough also have captured pinnipeds for scientific research. FWS has experience in Alaska with the capture of walrus, sea otters, and polar bears.

It is recommended that NMFS develop teams that can carry out live capture operations on all coasts for cetaceans and pinnipeds. Each capture team should have individuals experienced in taking samples and cooperating veterinary personnel to monitor and ensure the safety and humane handling of the animals. A list of veterinarians who would be willing to participate in such operations should be developed in advance.

NMFS also should locate sources of specialized equipment needed for each of the teams and/or purchase such equipment. Depending on the local area, such equipment may be available from a number of different sources. Although it can be assumed that boats can be located relatively easily in the area of a capture, equipment such as specialized netting may be difficult to obtain in a timely fashion.

Live capture emergency authorizations may be issued by the NMFS Office of Protected Resources (301) 713-2289 or the FWS Permit Office (703) 358-2104. Such authorizations will only be issued if the Working Group has recommended such action in order to determine the cause of an event. Requests for live capture authorizations must contain the following information:

1) The questions or uncertainties that can be addressed by a live capture operation;

2) The location(s) of captures and the numbers of animals proposed to be captured. If variables such as age or sex of animals are to be considered in capture operations, they should be noted;

3) If the request involves sacrifice of animals, an explanation of why non-lethal methods are unacceptable must be included;

4) A description of the methods, equipment, and personnel to be involved in the capture. The proposal must contain adequate measures to ensure the safety of the marine mammals and humans involved. It should also identify veterinary personnel involved; and

5) A complete protocol listing the tissues to be collected, how they will be collected and preserved, and the analyses to be performed. The request for such an authorization must also specify what facility or facilities will perform the analyses.

Before issuing an emergency authorization, FWS or NMFS will forward the request as soon as feasible to the Marine Mammal Commission for independent review and comment. 


\section{Independent Research}

FWS and NMFS recognize that mortality events may provide an opportunity to conduct independent research related to the ongoing investigation or to address other scientific questions. To the extent feasible, NMFS and FWS will attempt to accommodate outside requests for tissues if they do not inhibit the ongoing investigation. Even if approved, the availability of tissues will be subject to the willingness of participants in the response to collect and preserve tissues for the independent researcher. It should be recognized that time constraints may prevent such actions, and the individuals harvesting tissues are under no compulsion to provide samples for independent research. Requests for utilization of tissues will be approved under the following conditions:

1) An acceptable scientific protocol must be submitted that describes the analyses to be performed, their objectives, a description of the methodology to be used, and the methods used to preserve the tissues. If the proposed research is related to the ongoing investigation, it will be reviewed by the Onsite Coordinator and the Working Group. If unrelated to the ongoing investigation, the proposed research will be reviewed by the NMFS Office of Protected Resources (301) 713-2322 or the FWS Office of Management Authority (703) 358-2104 in consultation with the Marine Mammal Commission.

2) Requests for tissues may not compromise the availability of tissues for other analyses being conducted under the authority of the Onsite Coordinator including the maintenance of replicate samples.

3) Until the completion of the investigation, data obtained from authorized independent research projects may not be released to the public without the advance approval of the Onsite Coordinator.

4) Unless explicitly authorized by the Onsite Coordinator, approval of an independent research proposal will not include the authority to collect stranded animals or tissues therefrom.

5) Participants in the response who are collecting tissues are under no compulsion to provide tissues to independent researchers. It is recommended that independent researchers provide tissue collection, preparation, and mailing materials to the individual or organization harvesting tissues.

\section{Mass Strandings}

Odontocete species periodically mass strand. A mass stranding is a simultaneous stranding of an entire group of marine mammals. Although they are not necessarily unusual, mass strandings do represent a special circumstance when a mobilization is necessary to rescue as many of the animals as feasible. The response must be rapid, and the procedures of consulting the Working Group and appointing an Onsite Coordinator will not be possible. Protocols are currently in place for responding to mass strandings in Massachusetts, Florida, California, 
Oregon, and Washington. The protocols differ according to available resources. On Cape Cod, where there are more mass strandings than in any other area, an elaborate protocol has been set up including a phone tree for over 500 volunteers, check-in procedures at the site, triage procedures, ocean holding sites for live animals, and a list of local jurisdictions that are willing to provide assistance. In California, where few mass strandings have occurred, the protocol is primarily designed to ensure that lines of authority are established and local resources are identified.

Although the first priority of a response to a mass stranding is human safety and the welfare of the animals, such an event may provide the opportunity to gain knowledge about particular species. Knowledge of the biology of the Atlantic white-sided dolphin (Lagenorhynchus acutus) (St. Aubin and Geraci, 1979 and Sergeant et al, 1980), the spinner dolphin (Stenella longirostris) (Mead et al, 1980), and the false killer whale (Pseudorca crassidens) (Odell et al, 1980) increased markedly as a result of information gained from mass strandings. If an unusual species is involved in a mass stranding, an effort should be made to collect a maximum amount of information from each animal.

Mass strandings have also been approved as a source of tissues for the National Marine Mammal Tissue Bank (NMMTB). The NMMTB has been set up to archive tissues that can be used for contaminant analysis. The tissues are collected following a rigorous protocol (available from the Office of Protected Resources (301) 713-2322) and preserved in liquid nitrogen at the National Instirute of Standards and Technology for retrospective analysis. Whenever a mass stranding occurs, the NMMTB should be contacted to determine if collection of tissues is feasible (301) 975-6291 or (301) 975-3112.

Because of the special circumstances involved and the difficulty in controlling costs, funds from the Marine Mammal Unusual Mortality Event Fund will not routinely be released for a response to a mass stranding. At the discretion of the Secretary of Commerce, compensation may be provided for specific expenses incurred in responding to a mass strandings. 


\section{POST-EVENT ACTIVITIES}

\section{Report}

The Onsite Coordinator will be responsible for preparing a report of the unusual mortality event. The report will be prepared in draft for peer review by the Working Group or any individuals that the Working Group may designate as peer reviewers.

The report will contain results of analyses even if they are not directly relevant to the ultimate finding(s) because they may contain valuable baseline information. The report also should provide an assessment of the response and suggestions for improving responses in the future, including suggestions for revisions in protocols and/or the Contingency Plan. The report should also acknowledge all of those who made a contribution.

The report also will contain an assessment of the impact of the mortality event on the affected population(s). In some instances when a limited mortality event has affected a large marine mammal population, the conclusion may be that the event only had a minimal impact. If there has been a large-scale mortality or a vulnerable population has been affected, a more detailed analysis will be necessary. In order to accomplish such a task, it may be necessary to develop an estimate of total mortality in relation to abundance estimates and information on population dynamics, e.g., have specific age cohorts been disproportionately affected. If there is evidence of a significant impact, the report may contain recommendations for population monitoring. Such recommendations may include survey and research projects to better characterize population abundance and dynamics. Because such activities are part of the general management mandates given to FWS and NMFS, they should be incorporated into the more generic management programs of the agencies.

As a general principle, monitoring activities and/or specific recovery actions (and possibly preparation of a conservation or recovery plan) probably are warranted if there is evidence that a mortality event has reduced a population beneath its Optimum Sustainable Population (OSP) level. For species that are beneath OSP, i.e., depleted, threatened, or endangered, a mortality event that affects more animals than an annual net recruitment level may require population monitoring. In the case of cetaceans, the default value for this figure will be a mortality level of two percent of the population. In the case of pinnipeds, the same threshold would be a mortality level of six percent of the population.

\section{Follow-up Activities}

Once the report is finalized, copies will be provided to those who contributed, and it will be released to the public. When the report is released, all data, information, and results of analyses will be available to the public.

In past mortality events, one of the post-event activities that is easiest to accomplish has sometimes been neglected. The participants in a response should receive thanks for their efforts. Given the volunteer nature of the Stranding Network, receipt of information on the results of their efforts and an acknowledgement that their efforts have been appreciated provide incentives for continuing participation. The Onsite Coordinator is responsible for these actions. 


\section{Tissue Access}

The agency responsible for the response will set conditions for access to tissues used in the investigation. In instances when researchers want to examine things such as histopathology slides, access should be unimpeded. If a researcher requests tissues that could result in destructive analysis of the tissue, a decision will be made based on an assessment of the proposed research activity, the availability of appropriate tissues, and the need to retain archival tissues.

\section{Post-Event Monitoring}

Even after an unusual mortality event has run its course, there may be a reason to continue monitoring an individual population for additional impacts. If continued monitoring is determined to be necessary, the Working Group will prescribe which tissues should be collected and what analyses should be performed. It is not intended that the full set of analyses performed during the response to the mortality event should be prescribed. Post-event collection activities shall be communicated to members of the Stranding Networks. Such post-event monitoring activities will not be funded from the Marine Mammal Unusual Mortality Event Fund. Instead, such activities should be considered part of the individual agency's normal management responsibilities under other provisions of the MMPA or, when appropriate, the Endangered Species Act. 


\section{REFERENCES}

Akin, P. A., K. M. Peltier, and R. B. Miller. 1993. Techniques for the preparation and examination of reproductive samples collected from dolphins in the eastern tropical Pacific. U.S. Dep. Commer., NOAA Tech. Memo NMFS-SWFSC-192, La Jolla, Cal., $26 \mathrm{p}$.

Bonde, R. K., T. J. O'Shea, and C. A. Beck. 1983. Manual of procedures for the salvage and necropsy of carcasses of the West Indian manatee (Trichechus manatus). Nat. Tech. Inform. Serv., Springfield, Va, Publ. No. PB-83-255273, 175 p.

DeGange, A. R. and M. M. Vacca. 1989. Sea otter mortality at Kodiak Island, Alaska, during summer 1987. Journal of Mammalogy, 70:836-838.

Dierauf, L. A. (Editor). 1990. CRC Handbook of Marine Mammal Medicine: Health, Disease, and Rehabilitation. CRC Press, Boca Raton, Fl., 735 p.

. 1994. Pinniped forensic, necropsy and tissue collection guide. U.S. Dep. Commer., NOAA Tech. Memo. NMFS-OPR-94-3, 80 p.

., D. J. Vandenbroek, J. Roletto, M. Koski, L. Amaya, and L. J. Gage. 1985. An epizootic of leptospirosis in California sea lions. Journal of the American Veterinary Medical Association, 187:1145-1148.

Domingo, M., L. Ferrer, M. Pumarola, A. Marco, J. Plana, S. Kennedy, M. McAliskey, and B. K. Rima. 1990. Morbillivirus in dolphins. Nature, 348:21.

Galloway, S. B. and J. Ahlquist (Editors). In press. Forensic manual for the analysis of marine animal tissues. NOAA Tech. Memo.

Geraci, J. R. 1989. Clinical investigation of the 1987-88 mass mortality of bottlenose dolphins along the U.S. central and south Atlantic coast. Report to National Marine Fisheries Service, U.S. Office of Naval Research, and Marine Mammal Commission, Washington D.C., 63 p.

. and V. J. Lounsbury. 1993. Marine Mammals Ashore, a Field Guide for Strandings. Texas A\&M University Sea Grant College Program, Galveston. 305 p.

., D. J. St. Aubin, I. K. Barker, R. G. Webster, V. S. Hinshaw, W. J. Bean, H. L. Ruhnke, J. H. Prescott, G. Early, A. S. Baker, S. Madoff, and R. T. Schooley. 1982. Mass mortality of harbor seals: pneumonia associated with influenza A virus. Science, 215:1129-1131.

., D. M. Anderson, R. J. Timperi, D. J. St. Aubin, G. A. Early, J. H. Prescott, and C. A. Mayo. 1989. Humpback whales (Megaptera novaeangliae) fatally poisoned by 
dinoflagellate toxin. Canadian Journal of Fisheries and Aquatic Sciences, 46(11):1895-1898.

, P. J. Duignan, and G. Early. 1993. Survey for morbillivirus in pinnipeds along the northeastern coast. Final Report to National Marine Fisheries Service, Contract No. 50DGNF-2-00098, $95 \mathrm{p}$.

Gilmartin, W. G. 1987. Hawaiian monk seal die-off response plan, a workshop report. Southwest Fisheries Center Honolulu Laboratory, NMFS, National Oceanic and Atmospheric Administration (NOAA), Admin. Rep. H-87-19, Honolulu, Hawaii, 55 p.

Grachev, M. A., V. P. Kumarev, L. V. Mamaev, V. L. Zorin, L. V. Baranova, N. N. Denikina, S. I. Belikov, E. A. Petrov, V. S. Kolesnik, R. S. Kolesnik, V. M. Dorofeev, A. M. Beim, V. N. Kudelin, F. G. Nagieva, and V. N. Sidorov. 1989. Distemper virus in Baikal seals. Nature, 338:209.

Hansen, L. J. (Editor). 1992. Report on investigation of 1990 Gulf of Mexico bottlenose dolphin strandings. Southeast Fisheries Center, NMFS, NOAA, Report MIA-92-93-21, Miami, $219 \mathrm{p}$.

Hinshaw, V. S., W. J. Bean, R. G. Webster, J. E. Rehg, P. Fiorelli, G. Early, J. R. Geraci, and D. J. St. Aubin. 1984. Are seals frequently infected with avian influenza viruses? Journal of Virology, 51(3):863-865.

Jefferson, T. A., A. C. Myrick, Jr., and S. J. Chivers. 1994. Small cetacean dissection and sampling: a field guide. NOAA Tech. Memo. NMFS-SWFSC-198, La Jolla, Cal., 54 p.

Lipscomb, T. P., F. Y. Schulman, D. Moffett, and S. Kennedy. 1994. Morbilliviral disease in Atlantic bottlenose dolphins (Tursiops truncatus) from the 1987-88 epizootic. Journal of Wildlife Diseases, 30(4):567-571.

Lipscomb, T. P., S. Kennedy, D. Moffett, A. Krafft, B. A. Klaunberg, J. H. Lichy, G. T. Regan, and J. K. Tauenberger. In Press. Morbilliviral epizootic in Atlantic bottlenose dolphins of the Gulf of Mexico. Journal of Veterinary Diagnostic Investigation.

Loughlin, T. R. (Editor). 1994. Marine Mammals and the Exxon Valdez. Academic Press, San Diego, 395 p.

Mead, J. G., D. Odell, R. Wells, and M. Scott. 1980. Observations on a mass stranding of spinner dolphin, Stenella longirostris, from the west coast of Florida. Fishery Bulletin, 78(2):353-360.

Miller, W. G. 1992. An investigation of bottlenose dolphin Tursiops truncatus deaths in East Matagorda Bay, Texas, January 1990. Fishery Bulletin, 90(4):791-797.

Odell, D. K., E. Asper, J. Baucom, and L. Cornell. 1980. A recurrent mass stranding of the false killer whale, Pseudorca crassidens, in Florida. Fishery Bulletin, 78(1): 171-177. 
O'Shea, T. J., G. B. Rathbun, R. K. Bonde, C. D. Buergelt, and D. K. Odell. 1991. An epizootic of Florida manatees associated with a dinoflagellate bloom. Marine Mammal Science, 7:165-179.

Osterhaus, A. D. M. E. and E. J. Vedder. 1988. Identification of virus causing recent seal deaths. Nature, 335:20.

Regional Organization for the Protection of the Marine Environment (ROPME), Kuwait. 1986. First meeting of experts on mortality of marine animals, report of the meeting. ROPME Report WG.24/3, Kuwait, 39 p.

Sergeant, D. E., D. J. St. Aubin, and J. R. Geraci. 1980. Life history and northwest Atlantic status of the Atlantic white-sided dolphin, Lagenorhynchus acutus. Cetology, No. 37, 12 p.

St. Aubin, D. J. and J. R. Geraci. 1979. Strandings: a rare look into the biology of the Atlantic white-sided dolphin, Lagenorhynchus acutus. Pp. 190-206 in J. R. Geraci and D. J. St. Aubin (Editors), Biology of Marine Mammals: Insights through Strandings. Marine Mammal Commission Report No. MMC-77/13, Washington, D.C.

Trillmich, F. and K. A. Ono (Editors). 1991. Pinnipeds and El Niño. Springer-Verlag, New York. $293 \mathrm{pp}$.

Vidal, O. and J. P. Gallo. In press. Die-offs of marine mammals and sea birds in the Gulf of California, Mexico. Marine Mammal Science.

Wilkinson, D. M. 1991. Report to the Assistant Administrator for Fisheries. Program Review of the Marine Mammal Stranding Networks. U.S. Dep. Comm., NOAA, NMFS, Silver Spring, Maryland, $171 \mathrm{p}$.

Williams, T. M. and R. W. Davis. 1995. Emergency Care and Rehabilitation of Oiled Sea Otters: A Guide for Oil Spills Involving Fur-Bearing Marine Mammals. University of Alaska Press, Fairbanks, Alaska, 279 p. 


\section{ADDENDUM A \\ STRANDING NETWORK MEMBERS BY STATE}

Note: To safeguard the privacy of non-governmental Stranding Network members, addresses are limited to the city, and telephone numbers are not provided when there may be an issue of personal privacy. FWS and NMFS Regional Offices have this information as well as FAX numbers and, in some instances, the capability of communicating with Network members via computer. It should be noted that Stranding Network members may be authorized for different levels of activity depending on their level of expertise.

\section{MANATEES}

A toll-free number has been set up in Florida to report manatee strandings. It is 1-800-342-5367.

The Manatee Coordinator for U.S. Fish and Wildlife Service is in the Jacksonville, FL, office, (904) 232-2580. Other FWS Offices in the Region are:

Endangered Species Division

U.S. Fish and Wildlife Service

75 Spring Street, S.W.

Atlanta, GA 30303

(404) 679-7096

Chassahowitzka National Wildlife Refuge

7798 S. Suncoast Blvd.

Homosassa, FL 32646

(904) 563-2088

\section{Network Members}

Marine Mammal Pathobiology Laboratory

Florida Department of Environmental

Protection

3700 54th Ave., S.

St. Petersburg, FL 33711

(813) 893-2904

Jacksonville Field Station

Florida Department of Environmental

Protection

7825 Baymeadows Way

Central Building, Suite 200B

Jacksonville, FL 32256-7577

(904) 723-5845
Tequesta Field Station

Florida Department of Environmental

Protection

19100 S.E. Federal Highway

Tequesta, FL 33469-1712

(407) 575-5407

Melbourne Field Station

Florida Department of Environmental

Protection

Melbourne, FL

(407) 984-7757 
Port Charlotte Field Station

Florida Department of Environmental

Protection

Port Charlotte, FL

(941) 255-0777

Office of Protected Species Management

Florida Department of Environmental

Protection

Marjory Stoneman Douglas Bldg.

3900 Commonwealth Blvd.

Tallahassee, FL 32399

(904) $922-4330$

Sirenia Project Laboratory

National Biological Service

412 N.E. 16th Ave., Room 250

Gainesville, FL 32601

(904) 372-2571

Dr. John E. Reynolds, III

Department of Biology and Marine Science

Eckerd College

St. Petersburg, FL 33733

(813) 864-8431

Miami Seaquarium

4406 Rickenbacker Causeway

Miami, FL 33149

(305) 361-5705 ext. 240

Living Sea/Epcot Center

P.O. Box 10,000

Lake Buena Vista, FL 38830-1000

(407) 560-7688

Sea World of Florida

7007 Sea World Drive

Orlando, FL 32821

(407) 363-2364

Lowry Park Zoo

7530 North Blvd.

Tampa, FL 33604

(813) $935-8552$
Homosassa Springs State Wildlife Park

9225 West Fishbowl Drive

Homosassa, FL 32646

(904) 628-5343

Florida Marine Patrol

1-800-DIAL-FMP

Blue Spring State Park

2100 West French Ave.

Orange City, FL 32763

(904) 775-3663

Dolphin Research Center

P.O. Box 2875

Marathon Shores, FL 33052

(305) 289-0002

Rookery Bay National Estuarine Research Reserve

10 Shell Island Road

Naples, FL 33962

(941) $775-8845$

Amber Lake Wildlife Refuge and

Rehabilitation Center

297 Artists Ave.

Englewood, FL 34223

(941) 475-4585

Mote Marine Laboratory

1600 Thompson Parkway

Sarasota, FL 34236

(941) 388-4441

Marineland of Florida

9507 Ocean Shore Blvd.

Marineland, FL 32086-9602

(904) 471-1111

Caribbean Stranding Network

Department of Marine Sciences

University of Puerto Rico, RUM

P.O. Box 908

Lajas, Puerto Rico 00667-0908

(809) 899-2048 


\section{SEA OTTERS IN CALIFORNIA}

The Sea Otter Hotline Number is (408) 648-4829. The U.S. Fish and Wildlife Office in

Ventura, CA, is responsible for administration, (805) 644-1766.

Network Members--Live Sea Otters

Marine Mammal Center (Sausalito) (415) 289-7325

Monterey Bay Aquarium (Monterey) (408) 648-4829 or (408) 649-4840

Sea World of California (San Diego) (619) 226-3830 or (619) 222-6362

Network Members--Dead Sea Otters

Ano Nuevo Area:

Ray Bandar-California Academy of Sciences

(415) 334-6341

Karen Cebra-California Academy of Sciences $\quad$ (415) 750-7177

Burney Le Boeuf-U.of Cal., Santa Cruz

(408) 459-2845

Santa Cruz Area:

Jim Estes-National Biological Service (408) $459-2820$

Mike Kenner-National Biological Service (408) 459-3244

Monterey Area:

Michelle Staedler-Monterey Bay Aquarium (408) 648-4976

Alisa Giles-Monterey Bay Aquarium

(408) $648-4973$

Jack Ames-Cal. Dept. of Fish and Game

(408) 649-2893

Cambria and San Simeon Area:

Brian Hatfield-National Biological Service

(805) 927-3893

Morro Bay Area:

Fred Wendell-Cal. Dept. of Fish and Game

(805) 772-1714

Michael Harris-Cal. Dept of Fish \& Game

(805) $772-1135$

Santa Barbara and Ventura Area:

Kate Symonds-U.S. Fish \& Wildlife Service

(805) 644-1766 


\section{POLAR BEARS, SEA OTTERS, AND WALRUS IN ALASKA}

Marine Mammals Management

U.S. Fish and Wildlife Service

1011 East Tudor Road

Anchorage, AK 99503-6199

(907) $786-3800$

\section{NMFS NORTHEAST REGION}

The NMFS Northeast Regional Stranding Coordinator is in the NMFS Regional Office in Gloucester, MA, (508) 281-9138.

Maine

Tom Fernald

Allied Whale

College of the Atlantic

105 Eden Street

Bar Harbor, ME 04609

(207) 288-5015

James Gilbert

University of Maine

School of Forest Resources

Orono, ME 04469

(207) $581-2866$

\section{Massachusetts}

Governmental Units

NMFS Northeast Region

One Blackburn Drive

Gloucester, MA 01930-2298

(508) 281-9138 or (508) 281-9328

Marine Mammal Investigation

NMFS Northeast Fisheries Science Center

166 Water Street

Woods Hole, MA 02543-1026

(508) 548-5123
National Park Service

Cape Cod National Seashore

South Wellfleet, MA 02663

(508) 349-3785

U.S. Fish and Wildlife Service--Region 5

300 Westgate Center Drive

Hadley, MA 01035-9589

(413) 253-8615

Massachusetts Division of Fish and Wildlife

Nongame and Endangered Species

100 Cambridge Street

Boston, MA 02202

(617) $727-3151$

Massachusetts Coastal Zone Management

100 Cambridge Street, Room 2000

Boston, MA 02202

(617) $727-9530$

Non-governmental Units

New England Aquarium

Central Wharf

Boston, MA 02110

(617) 973-5246, Hotline: (617) 973-5247

Note: the Aquarium is the Letterholder for the State. Others are those who may be called upon for mass strandings and/or to supplement response. 
Mason Weinrich

Cetacean Research Unit

P.O. Box 159

Gloucester, MA 01930

(508) 281-6351

New England Whale Watch

54 Merrimack Street

Newburyport, MA 01912

(508) 465-7165

Center for Coastal Studies

P.O. Box 1036

Provincetown, MA 02657

(508) 487-3622

Cape Marine Animal Rescue and Conservation, Inc.

Box 1524

Brewster, MA 02631

(508) 896-3328

International Wildlife Coalition

70 E. Falmouth Highway

E. Falmouth, MA 02536

(508) $548-8328$, Ext. 220 or 200

International Fund for Animal Welfare

382 Woods Hole Road

Falmouth, MA 02540

(508) $540-8335$

Woods Hole Oceanographic Institute

Woods Hole, MA 02543

(508) 457-2000

\section{Connecticut}

Mystic Aquarium

55 Coogan Blvd.

Mystic, CT 06355-1997

(203) 536-9631, Ext. 107

Note: Also provides coverage for Rhode

Island.

\section{New York}

Wildlife Resources Center

NYSDEC - Nongame Unit

Delmar, NY 12054-9767

(518) 439-0198

OKEANOS Ocean Research Foundation 431 East Main Street

Riverhead, NY 11901

(516) $369-9840$

Aquarium for Wildlife Conservation

Surf Avenue and West 8th Street

Brooklyn, NY 11224

(718) 265-3440

New Jersey

Marine Mammal Stranding Center

P.O. Box 773

Brigantine, NJ 08203

(609) 266-0538

Delaware

Delaware Division of Fish and Wildlife

P.O. Box 1401

Dover, DE 19903

(302) $739-4782$

\section{Maryland}

Oxford Cooperative Laboratory

Maryland Department of Natural Resources

904 S. Morris Street

Oxford, MD 21654

(410) $576-3853$

National Aquarium in Baltimore

Pier 3, 501 E. Pratt Street

Baltimore, MD 21202

(410) $450-3852$ 
Assateague Island National Seashore

7206 National Seashore Lane

Berlin, MD 21811

(410) 641-1443

\section{Virginia}

Virginia Marine Science Museum

717 General Booth Blvd.

Virginia Beach, VA 23451

(804) 437-4949

Virginia Institute of Marine Science

College of William and Mary

Gloucester Point, VA 23062

(804) 642-7313

Virginia Department of Game and Inland

Fisheries

4010 Broad Street

P.O. Box 11104

Richmond, VA 23230-1104

(804) 367-1000

\section{Other}

Dr. James Mead and Charles Potter of the Division of Mammals, National Museum of Natural History, Smithsonian Institution, Washington, D.C. 20560, (202) 357-1923, have as much experience in responding to stranded animals and collecting tissues from them as anyone in the country.

\section{NMFS SOUTHEAST REGION}

The Regional Coordinator for the Southeast Stranding Network is in the NMFS Regional Office in St. Petersburg, FL, (813) 570-5312. In addition, the NMFS Southeast Fisheries Science Center has assumed the major role in working with the Network. They have set up a NMFS State Representative system based out of NMFS laboratories to work with Network members and move reporting closer to real time. The Coordinator of this system is based at the NMFS Southeast Fisheries Science Center in Miami, FL, (305) 361-4299 or (305) 361-4264. The current NMFS Stranding Network Representatives are: 


\section{North Carolina}

Vicky Thayer

NMFS Beaufort Laboratory

101 Pivers Island Road

Beaufort, NC 28516-9722

(919) $728-8740$

\section{South Carolina, Georgia}

Wayne McFee

NMFS Charleston Laboratory

P.O. Box 12607

Charleston, SC 29422-2607

(803) $762-1200$

\section{East and South Florida}

Ben Blaylock, Blair Mase, and Jim Tobias

NMFS Miami Laboratory

75 Virginia Beach Drive

Miami, FL 33149

(305) $361-4586$ or (305) 361-5761

24 hour pager (305) 862-2850

\section{West Florida}

Jeff Brown

NMFS Southeast Regional Office

9721 Executive Center Drive, N.

St. Petersburg, FL 33702-2432

(813) $570-5312$

\section{Florida Panhandle}

Bill Fable

NMFS Panama City Laboratory

3500 Delwood Beach Road

Panama City, FL 32408-7403

(904) 234-6541
Alabama, Mississippi, and Louisiana

Wayne Hoggard and Kevin Rademacher

NMFS Mississippi Laboratory

P.O. Drawer 1207

Pascagoula, MS 39568-1207

(601) 762-4591

\section{Texas}

Charles Caillouet and Dickie Revera NMFS Galveston Laboratory 4700 Avenue G

Galveston, TX 77551-5997

(409) $766-3500$ 
In addition, a scientific coordinator has been designated for the Southeast Region. He is Dan Odell, Sea World of Florida, Orlando, Florida, (407) 363-2662.

Stranding Network participants are:

\section{North Carolina}

National Marine Fisheries Service

Beaufort Laboratory

101 Pivers Island Road

Beaufort, NC 28516-9722

(919) $728-8740$

North Carolina Division of Marine Fisheries

Morehead City

(919) 726-7021

North Carolina Office of Marine Affairs

417 Blount Street

Raleigh, NC 27601

(919) 733-2290

North Carolina State Museum of Natural

History

102 North Salisbury

Raleigh, NC 27601

(919) 733-7450

Environmental Management Dept.

U.S. Marine Corps Base, Bldg. 103

Camp LeJeune, NC 28542

(910) 451-2195

Keith Rittmaster

North Carolina Maritime Museum

Beaufort, NC 28516

(919) 728-7317

Jean Beasley

Surf City
Dr. Mary Burkart

Roanoke Island Animal Clinic

P.O. Box 1275

Manteo, NC 27954

(919) 473-3117

Dr. Claire Hohenwarter

Wilmington

Amanda Noe

Wilmington

George Roundtree

Wilmington

Dr. Dwight Shumway

Outer Banks Animal Hospital

Outer Banks Mall

U.S. 158

Nagshead, NC 27959

(919) 441-6066

Dr. Walter Westbrook

Newport Animal Clinic

444 Howard Blvd.

Newport, NC 28570

(919) 223-5115

Marine Biomedical Center

Duke University Marine Laboratory

Beaufort, NC 28516

(919) $728-2111$

Dr. Stephen Jaffe

Wilmington 
Dr. Suzanne Botts

Experimental Pathology Laboratories, Inc.

P.O. Box 12766

Research Triangle Park, NC 27709

(919) 544-8061

Dr. R. Guy Jaconis

Beaufort

North Carolina State Aquarium/Fort Fisher

P.O. Box 130

Kure Beach, NC 28449

(910) 458-8258

North Carolina State Aquarium/Roanoke Island

P.O. Box 967

Manteo, NC 27954

(919) 473-3494

North Carolina State Aquarium/Pine Knoll Shores

P.O. Box 580

Atlantic Beach, NC 28512

(919) 247-4004

College of Veterinary Medicine

North Carolina State University

4700 Hillsborough Street

Raleigh, NC 27606

(919) $829-4200$

Dr. W. David Webster

Dept. of Biological Sciences

University of North Carolina at Wilmington

601 South College Road

Wilmington, NC 28403-3497

(910) 395-3756

Cape Lookout National Seashore

3601 Bridges Street, Suite F

Morehead City, NC 28557

(919) 728-2250
Bald Head Island Conservancy

P.O. Box 3109

Bald Head Island, NC 28461

(910) 457-0089

Cape Hatteras National Seashores

Route 1, Box 675

Manteo, NC 27954

(919) 473-2111

Hammocks Beach State Park

Route 2, Box 295

Swansboro, NC 28584

(910) 326-4881

Fort Macon State Park

P.O. Box 127

Atlantic Beach, NC 28512

(919) 726-3775

\section{South Carolina}

Sally Murphy--State Coordinator

South Carolina Wildlife and Marine

Resources Department

217 Ft. Johnson Road

P.O. Box 12559

Charleston, SC 29422-2559

(803) 795-6350

NMFS Charleston Laboratory

P.O. Box 12607

Charleston, SC 29412

(803) $762-1200$

Charleston Museum

360 Meeting Street

Charleston, SC 29403

(803) 722-2996

Hunting Island State Park

1775 Sea Island Parkway

St. Helena Island, SC 29920

William Bell

N. Myrtle Beach 
Rob Young

Coastal Carolina College

P.O. Box 1954

Conway, SC 29526

(803) 349-2277

Jim Burton

Surfside Beach

Chris Marlow

Pawleys Island

Jeffrey McClary

Pawleys Island

Mark Spinks

Georgetown

Cape Romain National Wildlife Refuge Awendaw

(803) 928-3368

Watson McCaskill

Awendaw

Beth Rice

Sullivans Island

Dan O'Brien

Folly Beach

Bob Cowgill

Kiawah Island

George Walther

Kiawah Island

Lynn Burnett

Johns Island

Sally Whitner

Johns Island

Charlotee Hope

Edisto Island
Tom Murphy

Green Pond

Betty Sobol

Fripp Island

Mike Walker

St. Helena Island

Ed Caine

Beaufort

Nancy Polk-Weckhorst

Hilton Head Island

Ed Drane

Hilton Head Island

\section{Georgia}

Mike Harris--State Coordinator

Georgia Department of Natural Resources

One Conservation Way

Brunswick, GA 31520

(912) 264-7218

Gray's Reef National Marine Sanctuary

P.O. Box 13687

Savannah, GA 31416

(912) 598-2345

\section{Florida}

NMFS Southeast Fisheries Science Center 75 Virginia Beach Drive

Miami, FL 33149

(305) 361-4299

NMFS Panama City Laboratory

3500 Delwood Beach Road

Panama City, FL 32407

(904) 234-6541 
NMFS Southeast Regional Office 9721 Executive Center Drive, N.

St. Petersburg, FL 33702-2432

(813) $570-5312$

Florida Department of Environmental

Protection

Jacksonville Field Station

7825 Baymeadows Way

Central Building, Suite 200B

Jacksonville, FL 32256-7577

(904) 448-4300, Ext. 222

Marineland of Florida 9507 Ocean Shore Blvd.

Marineland, FL 32086-9602

(904) 471-1111

Sea World of Florida

7007 Sea World Drive

Orlando, FL 32821

(407) $351-3600$

Hubbs-Sea World Research Institute P.O. Box 691602

Orlando, FL 32869-1602

(407) $363-2662$

Dr. Lewellyn Ehrhart

Department of Biological Sciences

University of Central Florida

P.O. Box 25000

Orlando, FL 32816

(407) $823-2970$

The Bionetics Corporation

Mail Code BIO-2

Kennedy Space Center, FL 32899

(407) 853-3281

Florida Department of Environmental

Protection

Indian River Field Station

328 W. Hibiscus Blvd.

Melbourne, FL 32901-6988

(407) $984-4828$
Florida Institute of Technology

$150 \mathrm{~W}$. University Blvd.

Melbourne, FL 32901

(407) $768-8000$, Ext. 7283

Ecological Associates, Inc.

P.O. Box 405

Jensen Beach, FL 34958-0974

(407) 334-3729

Florida Marine Conservation Corporation 12295 Indian Mound Road

Lake Worth, FL 33467

(407) 798-8201

Florida Department of Environmental

Protection

Tequesta Field Station

19100 S.E. Federal Highway

Tequesta, FL 33469-1712

(407) 575-5407

Department of Biological Sciences

Florida Atlantic University

Boca Raton, FL 33431

(305) 361-3793

Miami Seaquarium

4400 Rickenbacker Causeway

Miami, FL 33149

(305) $361-5705$, Ext. 240

Marine Mammal Rescue Foundation of the Upper Keys, Inc.

P.O. Box 2728

Key Largo, FL 33037

(305) 451-1993

Dolphin Research Center

P.O. Box 2875

Marathon Shores, FL 33052

(305) 289-1121 
Rookery Bay National Estuarine Research Reserve

10 Shell Island Road

Naples, FL 33962

(941) 775-8845

Florida Marine Mammal Stranding Network, Southwest Region

P.O. Box 07361

Ft. Meyers, FL 33919

(941) $335-2372,455-3139,597-3108$

Amber Lake Wildlife Refuge and

Rehabilitation Center

297 Artists Avenue

Englewood, FL 34223

(941) $475-4585$

Mote Marine Laboratory

1600 Thompson Parkway

Sarasota, FL 34236

(941) 388-4441

The Florida Aquarium

300 S. 13th Street

Tampa, FL 33602-5628

(813) 229-8861

Dr. John Reynolds, III

Department of Biology and Marine Science

Eckerd College

St. Petersburg, FL 33733

(813) 864-8431

Florida Department of Environmental

Protection

Marine Mammal Pathobiology Laboratory

3700 54th Ave., S.

St. Petersburg, FL 33711

(813) 893-2904

Dr. Bill Goldston

St. Petersburg
Clearwater Marine Science Center

249 Windward Passage

Clearwater, FL 33515

(813) 441-1790

Gulf World

15412 West Highway 98

Panama City Beach, FL 32407

(904) 234-5271

Gulfarium

Highway 98 East

Ft. Waiton Beach, FL 32548

(904) 243-9046

Gulf Islands National Seashore

1801 Gulf Breeze Parkway

Gulf Breeze, FL 32561

(904) 934-2617

EPA Laboratory

Sabine Island

Gulf Breeze, FL 32561-5299

(904) 934-9200

\section{Alabama}

Stranding Hotline (800) 799-6637

Spring Hill College

4000 Dauphin Street

Mobile, AL 36608

(205) 460-2239

Mississippi

Stranding Hotline (800) 799-6637

NMFS Pascagoula Laboratory

P.O. Drawer 1207

Pascagoula, MS 39567

(601) 762-4591 
Gulf Islands National Seashore

Mississippi District

3500 Park Road

Ocean Springs, MS 39564

(601) 875-9057

Gulf Coast Research Laboratory

P.O. Box 7000

Ocean Springs, MS 39566

(601) 872-4211

Marine Life Oceanarium

P.O. Box 4078

Gulfport, MS 39502-4078

(601) 864-2511

\section{Louisiana}

Stranding Hotline (800) 799-6637

Louisiana Department of Wildlife and Fisheries

Louisiana Natural Heritage Program

P.O. Box 98000

Baton Rouge, LA 70898-9000

(504) 765-2821

Texas

Stranding Hotline (800) 9-MAMMAL

NMFS Galveston Laboratory

4700 Avenue U, Building 303

Galveston, TX 77550

(409) $766-3500$

Texas Marine Mammal Stranding Network

Texas A\&M University

4700 Avenue U, Bldg 303

Galveston, TX 77551

(409) $740-4455$

Note: The Texas Network is administratively centralized through Texas A\&M University, but there are Network participants along the coast including:
University of Texas Medical Branch

Galveston

Texas Department of Parks and Wildlife Austin

Marine Science Institute

University of Texas

Port Aransas

Texas A\&M University-Corpus Christi Corpus Christi

University of Texas-Pan American

South Padre Island

Padre Island National Seashore

Corpus Christi

Sea World of Texas

San Antonio

Gladys Porter Zoo

Brownsville

Puerto Rico

Caribbean Stranding Network

Department of Marine Science

University of Puerto Rico

Apartado 980

Lajas, PR 00667-0908

(809) 899-2048 


\section{NMFS SOUTHWEST REGION}

The Stranding Network Coordinator is in the NMFS Southwest Regional Office in Long Beach, CA, (310) 980-4017. Stranding Network participants include:

\section{California}

Vertebrate Museum

Department of Zoology

Humboldt State University

Arcata, CA 95521

(707) $826-4872$

Northcoast Marine Mammal Center

424 Howe Drive

Crescent City, CA 95531

(707) $464-7448$

The Marine Mammal Center

Marin Headlands

Golden Gate National Recreation Area

Sausalito, CA 94965

(415) $289-7325$

Marine World Africa USA

100 Marine World Parkway

Vallejo, CA 94589

(707) 644-4000, Ext. 242

Northcoast Redwoods District

California Department of Parks and

Recreation

600-A West Clark Street

Eureka, CA 95501

(707) 445-6547

Redwood National Park

P.O. Box 7

Orick, CA 95555

(707) 464-6101

Humboldt Wildlife Care Center

Arcata

(707) $826-1583$
Marine Resources Division

California Department of Fish and Game

619 2nd Street

Eureka, CA 95501

(707) 445-6499

U.S. Coast Guard

Group Humboldt Bay

McKinleyville, 95521

(707) $822-7648$

Department of Biology

Mendocino Coast Branch

College of the Redwoods

1211 Del Mar Drive

Fort Bragg, CA 95437

(707) $961-1001$

Marine Resources Division

California Department of Fish and Game

19160 South Harbor Drive

Fort Bragg, CA 95437

(707) $964-9078$

Mendocino District

California Department of Parks and

Recreation

P.O. Box 440

Mendocino, CA 95460

(707) $937-5804$

Department of Ornithology and Mammalogy

California Academy of Sciences

Golden Gate Park

San Francisco, CA 94118

(415) $750-7177$ 
Museum of Vertebrate Zoology

University of California

2593 Life Sciences Building

Berkeley, CA 94720

(415) 642-1379

Point Reyes Bird Observatory

4990 Shoreline Highway

Stinson Beach, CA 94970

(415) $868-1221$

Point Reyes National Seashore

Point Reyes, CA 94956

(415) 663-8525

Bodega Marine Laboratory

University of California

Bodega, CA 94293

(707) 875-2211

Russian River District

California Department of Parks and Recreation

P.O. Box 123

Duncans Mills, CA 95430

(707) 865-2391

Doran Regional Park

P.O. Box 372

Bodega Bay, CA 94923

(707) $875-3540$

U.S. Coast Guard

MSO San Francisco Bay

Coast Guard Island, Building 14

Alameda, CA 94501

(415) 437-3073

U.S. Coast Guard, Pt. Brower

Yerba Buena Island

San Francisco, CA 94130

(415) 556-4471
U.S. Coast Guard

Station Rio Vista

900 Beach Drive

Rio Vista, CA 94571

(707) 374-2871

San Francisco Bay National Wildlife Refuge

P.O. Box 524

Newark, CA 94560

(415) $792-0222$

Golden Gate National Recreation Area

Fort Cronkhite, Building 1056

Sausalito, CA 94965

(415) 331-0744

Marine Resources Division

California Department of Fish and Game

411 Burgess Drive

Menlo Park, CA 94025

(415) 688-6340

Peninsula Humane Society

12 Airport Blvd.

San Mateo, CA 94401

(415) 688-6340

Bay Area District

California Department of Parks and

Recreation

95 Kelly Avenue

Half Moon Bay, CA 94019

(415) 726-6238

San Francisco Animal Control

1200 15th Street

San Francisco, CA 94103

(415) 554-6364

NMFS Office of Enforcement

Santa Rosa Federal Bldg., Room 203

777 Sonoma Avenue

Santa Rosa, CA 95404

(707) $578-3740$ 
Gulf of the Farallones National Marine Sanctuary

Fort Mason, Building 201

San Francisco, CA 94123

(415) 556-2587

Long Marine Laboratory Institute for Marine Studies

University of California

100 Shaffer Road

Santa Cruz, CA 95060

(408) $459-2883$

Santa Cruz Department of Parks and Recreation

323 Church Street

Santa Cruz, CA 95060

(408) 429-3777

Santa Cruz District

California Department of Parks and Recreation

101 Madeline Drive

Aptos, CA 95003

(415) 688-3241

Moss Landing Marine Laboratories

P.O. Box 450

Moss Landing, CA 95039

(408) 633-3304

Hopkins Marine Station

Stanford University

Cabrillo Point

Pacific Grove, CA 93950

(408) $373-6658$

SPCA of Monterey County

Animal Care Services

P.O. Box 3058

Monterey, CA 93942

(408) $372-7466$
Marine Resources Division

California Department of Fish and Game

2201 Garden Road

Monterey, CA 93940

(408) $649-2870$

Monterey District

California Department of Parks and

Recreation

2211 Garden Road

Monterey, CA 93940

(408) $384-7695$

U.S. Coast Guard

Group Monterey

100 Lighthouse Avenue

Monterey, CA 93940

(408) $375-2278$

Monterey Bay National Marine Sanctuary 2560 Garden Grove Road, \#101

Monterey, CA 93940

(408) $647-4208$

Vertebrate Laboratory

Santa Barbara Museum of Natural History

2559 Puesta Del Sol Road

Santa Barbara, CA 93105

(805) $687-4065$, Ext. 320

Piedras Blancas Research Station

National Biological Service

P.O. Box 70

San Simeon, CA 93452

(805) 927-3893

Marine Resources Division

California Department of Fish and Game

213-B Beach Street

Morro Bay, CA 93442

(805) 545-4439 
Marine Biology Laboratory

Pacific Gas and Electric

Diablo Canyon Nuclear Power Plant

P.O. Box 117

Mailstop BB6

Avila Beach, CA 93424

(805) 545-4439

Santa Barbara Marine Mammal Center

3930 Harold Avenue

Santa Barbara, CA 93110

(805) 687-3255

San Luis Obispo Coast District

California Department of Parks and

Recreation

3220 S. Higuera Street, Suite 311

San Luis Obispo, CA 93401

(805) $549-3312$

Pismo Dunes District

California Department of Parks and

Recreation

576 Camino Mercado

Arroyo Grande, CA 93420

(805) 489-2684

Environmental Division

$30 \mathrm{SPW} / \mathrm{ET}$

806 13th Street, Suite J

Vandenberg Air Force Base, CA 93437 (805) 866-9687

Marine Resources Division

California Department of Fish and Game 530 East Montecito Street, Room 104

Santa Barbara, CA 93103

(805) $568-1220$

Marine Resources Division

California Department of Fish and Game 330 Golden Shore, Suite 50

Long Beach, CA 90802

(310) $590-5117$
NMFS Office of Enforcement

501 West Ocean Blvd., Suite 4400-A

Long Beach, CA 90802

(310) $980-4052$

Long Beach Naval Shipyard

300 Skipjack Road

Code 106.331

Long Beach, CA 90822-5090

Channel Islands National Marine Sanctuary

113 Harbor Way

Santa Barbara, CA 93109

(805) 966-7101

Jalama Beach Park

Star Route

Lompoc, CA 93436

(805) 734-1446

Channel Coast District Office

California Department of Parks and

Recreation

1933 Cliff Drive

Santa Barbara, CA 93109

(805) 687-3714

Ventura Field Office

U.S. Fish and Wildlife Service

2493 Portola Road, Suite B

Ventura, CA 93003

(805) 644-1766

Environmental Division

Code P7320

Naval Air Station

Pt. Mugu, CA 93042-5000

(805) 989-3808

Animal Regulation Department

County of Ventura

600 Aviation Drive

Camarillo, CA 93010-8594

(805) 388-4344 
Channel Islands National Park

1901 Spinnaker Drive

Ventura, CA 93001

(805) 644-8157

Section of Mammals

Natural History Museum of Los Angeles

County

900 Exposition Blvd.

Los Angeles, CA 90007

(213) 585-5105

Los Angeles Humane Society

5026 West Jefferson Blvd.

Los Angeles, CA 90016

(213) $730-5338$

Los Angeles County Animal Control

29525 Agoura Road

Agoura, CA 91301

(818) $991-0070$

West Los Angeles Animal Care Center 11950 Missouri Avenue

Los Angeles, CA 90025

(213) 820-2691

Santa Monica Animal Shelter

1640 Ninth Street

Santa Monica, CA 90301

(310) 450-6179

Southern California Humane Society

12910 Yukon Avenue

Hawthorne, CA 90250

(310) 676-1149

Animal Control

City of Manhattan Beach

1400 Highland Avenue

Manhattan Beach, CA 90266

(310) 545-5621
Animal Control

City of Hermosa Beach

1315 Valley Drive

Hermosa Beach, CA 90254

(310) 318-0209

Animal Control

City of Redondo Beach

401 Diamond Street

Redondo Beach, CA 90277

(310) 318-0611

San Pedro Animal Regulation

735 Battery Street

San Pedro, CA 90731

(310) 831-2414

Long Beach Animal Control

3001 East Willow

Long Beach, CA 90806

(310) 595-5449

Beach Maintenance

City of Long Beach

205 Marina Drive

Long Béach, CA 90803

(310) 598-6628

Animal Control

City of Seal Beach

911 Seal Beach Blvd.

Seal Beach, CA 90740

(310) 431-2541

Friends of the Sea Lion Marine Mammal Center

20612 Laguna Canyon Road

Laguna Beach, CA 92651

(714) 494-3050

Safety and Sanitation Division

Department of Beaches and Harbors

County of Los Angeles

13737 Fiji Way

Marina del Rey, CA 90292

(310) 305-9550 
Marine Science Department

Orange Coast College

2701 Fairview Road

Costa Mesa, CA 92628

(714) $432-5564$

Santa Monica Harbor Patrol

Harbor Office

600 Santa Monica Pier

Santa Monica, CA 90401

(310) $458-8695$

Cabrillo Marine Aquarium

3720 Stephen White Drive

San Pedro, CA 90731

(310) 548-7562

Northern Section Lifeguard Headquarters

Department of Beaches and Harbors

County of Los Angeles

30050 W. Pacific Coast Highway

Malibu, CA 90265

(310) $457-9898$

Harbor Patrol

Port of Long Beach

925 Harbor Plaza Drive

Long Beach, CA 90802

(310) 590-4185

Environmental Management Division

Harbor Department

Port of Los Angeles

P.O. Box 151

San Pedro, CA 90733-0151

(310) $519-3675$

Central Section Lifeguard Headquarters

Department of Beaches and Harbors

County of Los Angeles

1642 The Promenade

Santa Monica, CA 90401

(310) 451-2906
Southern Section Lifeguard Headquarters

Department of Beaches and Harbors

Los Angeles County

1200 Strand Avenue

Hermosa Beach, CA 90254

(310) $372-2162$

Harbor Patrol

City of Redondo Beach

280 Marine Way

Redondo Beach, CA 90277

(310) 318-0632

San Pedro-Cabrillo Beach Headquarters

Department of Beaches and Harbors

County of Los Angeles

3720 Stephen White Drive

San Pedro, CA 90731

(310) 832-1138

Southern California Edison

2244 Walnut Grove Avenue

P.O. Box 800

Rosemead, CA 91770

(818) 302-9732

Scattergood Generating Station

12700 Vista Del Mar

Playa del Rey, CA 90293

(310) 832-1138

West Sector Ranger Station

California Department of Parks and

Recreation

9000 W. Pacific Coast Highway

Malibu, CA 90265

(818) 706-1310

Department of the Navy

Naval Weapons Station

Public Works-Code 0923

Seal Beach, CA 90740

(213) 594-7273 
Huntington Beach Area Office

California Department of Parks and Recreation

18331 Enterprise Lane

Huntington Beach, CA 92648

(714) $536-2581$

Beach Operations

City of Huntington Beach

103 Pacific Coast Highway

Huntington Beach, CA 92648

(714) $536-2581$

Orange County Animal Control

561 City Drive South

Orange, CA 92668

(714) 834-6957

Orange County Sheriff's Department

1901 Bayside

Corona del Mar, CA 92625

(714) 494-6571

Lifeguard Service

City of Newport Beach

3300 Newport Blvd.

Newport Beach, CA 92659-1761

(714) 673-3360

Newport Beach Animal Shelter

125 Mesa Drive

Costa Mesa, CA 92627

(714) 644-3656

Animal Shelter

City of San Clemente

320 Avenida Pico

San Clemente, CA 92672

(714) $361-8205$

Newport Beach Animal Control

870 Santa Barbara Drive

Newport Beach, CA 92658-7000

(714) 644-3717
City of Avalon

P.O. Box 707

Avalon, CA 90704

(310) $510-0221$

University of Southern California Marine Science Center

P.O. Box 398

Avalon, CA 90704

(310) 743-6792

Catalina Island Marine Institute

P.O. Box 796

Avalon, CA 90704

(310) $510-1622$

Fort MacArthur Marine Mammal Care

Center

3601 South Gaffey Street

San Pedro, CA 90731

(310) $548-5667$

Beach Lifeguard Service

City of Seal Beach

211 Eighth Street

Seal Beach, CA 90740

(310) $430-2613$

Catalina Island Lifeguard Headquarters

Department of Beaches and Harbors

County of Los Angeles

P.O. Box 385

Avalon, CA 90704

(310) 510-0856

Microbiology Section

Mail Stop 535

Hyperion Treatment Plant

12000 Vista Del Mar

Playa del Rey, CA 90293

(310) 648-5438

Regional Environmental Health Service

NRMC Branch Clinic

Terminal Island Naval Station

Long Beach, CA 90822 
Sea World of California

1720 South Shores Road

San Diego, CA 92109

(800) 541-7325

Naval Ocean Systems Center

Code 642

San Diego, CA 92152

(619) 553-1374

NMFS Southwest Fisheries Science Center

P.O. Box 271

La Jolla, CA 92038

(619) 546-7067

Hubbs-Sea World Research Institute 1700 South Shores Drive

San Diego, CA 92109

(619) 226-3870

Department of Animal Control

County of San Diego

Central Animal Shelter

5480 Gaines Street

San Diego, CA 92210

(619) 278-9760

North County Humane Society

2905 San Luis Rey Road

Oceanside, CA 92054

(619) $757-4357$

Animal Services

City of Coronado

578 Orange Avenue

Coronado, CA 92118

(619) $522-7371$

Department of Marine Safety

City of Solana Beach

P.O. Box 311

Solana Beach, CA 92075

(619) 755-1569
Southern Region Headquarters

California Department of Parks and

Recreation

8885 Rio San Diego Drive, Suite 270

San Diego, CA 92108

(619) 237-6770

NMFS Office of Enforcement

185 West F Street, Suite 405

San Diego, CA 92101

(610) $557-5494$

Office of Oil Spill Prevention and Response California Department of Fish and Game

P.O. Box 944209

Sacramento, CA 94244-2090

(916) 445-8285

\section{Hawaii}

All stranding responses in Hawaii are centrally coordinated by the NMFS Pacific Area Protected Species Program Coordinator, (808) 973-2987. All calls should initially be made to this office, and the office will make the follow-up calls. By island, Stranding Network participants include:

$\underline{\text { Kauai }}$

Division of Aquatic Resources

Hawaii Department of Land and Natural Resources

3060 Eiwa Street, Room 306

Lihue, HI 96766

Walter Haas, DVM and David Haas, DVM Lihue Veterinary Hospital

3113 Oihana Street

Lihue, HI 96766

Kauai National Wildlife Refuge

P.O. Box 87

Kilauea, HI 96754 
Kauai County Public Works

3021 Umi Street

Lihue, HI 96766

Hawaii

Division of Aquatic Resources

Hawaii Department of Land and Natural Resources

P.O. Box 936

Hilo, HI 96721

Hawaii County Public Works

630 Lanikaula Street

Hilo, HI 96720

U.S. Coast Guard

P.O. Box 4819

Hilo, HI 96720

Hawaii Preparatory Academy

P.O. Box 428

Kamuala, HI 96743

Marta Lepes, DVM

Hilo Veterinary Clinic

701 Kanoelehua Avenue

Hilo, HI 96720

$\underline{\text { Maui }}$

Roger Kehler, DVM

Kihei Veterinary Clinic

P.O. Box 1669

Kihei, HI 96753

Division of Aquatic Resources

Hawaii Department of Land and Natural Resources

70 S. High Street

Wailuku, HI 96793

Maui County Department of Public Works 200 S. High Street

Wailuku, HI 96793
U.S. Coast Guard

BMC Leavitt

Maalaea Road

Wailuku, HI 96793

Hawaiian Islands Humpback Whale National Marine Sanctuary

726 South Kihei Road

Kihei, HI 96753

$\underline{\text { Molokai }}$

Division of Aquatic Resources

Hawaii Department of Land and Natural Resources

Hoolehua, HI 96729

Maui County Department of Public Works

P.O. Box 526

Kaunakakai, HI 96748

$\underline{\text { Lanai }}$

Hawaii Department of Land and Natural Resources

P.O. Box 1

Lanai, HI 96763

Maui County Department of Public Works

P.O. Box 793

Lanai, HI 96763

$\underline{\text { Oahu }}$

NMFS Pacific Area Office

2570 Dole Street, Room 105

Honolulu, HI 96822

Sea Life Park

Makapuu Point

Waimanalo, HI 96795

Waikiki Aquarium

2777 Kalakaua Street

Honolulu, HI 96815 
Dave McKay, DVM

Kaneohe Veterinary Clinic

45-480 Kaneohe Bay Drive

Kaneohe, HI 96744

Howard Blatt, DVM

Honolulu

Michelle Magee, DVM

NOSC

P.O. Box 997

Kailua, HI 96734

Charla Jones, DVM

Kaneohe

Tom Sawa, DVM

Division of Animal Husbandry

Department of Agriculture

99-762 Moanalua Road

Aiea, HI 96701

Honolulu County Department of Public

Works

650 S. King Street

Honolulu, HI 96813

U.S. Coast Guard OLE

300 Ala Moana Blvd., Ninth Floor

Honolulu, HI 96850

Thierry Work, DVM

USFWS

3 Waterfront Plaza, Suite 580

500 Ala Moana Blvd.

Honolulu, HI 96813

Division of Aquatic Resources

Hawaii Department of Land and Natural

Resources

1151 Punchbowl Street, Room 330

Honolulu, HI 96813
Annette Freeman, DVM

NOSC

P.O. Box 997

Kailua, HI 96734

Hawaiian Islands Humpback Whale National Marine Sanctuary

P.O. Box 50186

Honolulu, HI 96850

Northwestern Hawaiian Islands

Marc Webber

USFWS

Tern Island National Wildlife Refuge

P.O. Box 50167

Honolulu, HI 96850 


\section{NMFS NORTHWEST REGION}

The Northwest Regional Stranding Coordinator is in the NMFS Northwest Regional Office, (206) 526-6733. Participants in the Stranding Network include:

\section{Oregon}

Oregon State Police

Central Dispatch

3710 Portland Road, N.E.

Salem, OR 97310

(800) $452-7888$

Wildlife Division

Oregon Department of Fish and Wildlife

P.O. Box 59

Portland, OR 97207

Oregon Department of Fish and Wildlife

Marine Science Drive, Bldg. 3

Newport, OR 97365

(503) $867-4741$

Oregon Department of Fish and Wildlife

P.O. Box 5430

Charleston, OR 97420

(503) $888-5515$

Oregon Department of Fish and Wildlife

P.O. Box 642

Gold Beach, OR 97444

(503) 247-2112

Oregon Department of Fish and Wildlife

Hamlet Route, Box 360

Seaside, OR 97138

(503) 738-7066

Oregon Department of Fish and Wildlife 4909 Third Street

Tillamook, OR 97141

(503) 842-2741
Oregon Department of Fish and Wildlife

575 N North Bank Road

Otis, OR 97368

(503) 994-8606

Oregon Department of Fish and Wildlife 17730 S.E. Evelyn Street

Clackamas, OR 97015

(503) 657-2000

Northwest Wildlife Rehabilitation Center 6265 Brickyard Road

Tillamook, OR 97141

(503) 842-2111

Free Flight Wildlife Rehabilitation Center 1185 Portland Avenue

Bandon, OR 97411

(503) 347-3882

Oregon Institute of Marine Biology

P.O. Box 5389

Charleston, OR 97420

(503) $888-2581$

Oregon State University

2030 S. Marine Science Drive

Newport, OR 97365

(503) $270-2381$ or (503) 867-0202

Oregon Coast Aquarium

P.O. Box 2000

Newport, OR 97365

(503) 867-3474

U.S. Coast Guard

2185 S.E. Airport Road

Warrenton, OR 97146-9693

(503) 861-0211 
U.S. Coast Guard

P.O. Box 167

Garibaldi, OR 97118

(503) 322-3531

U.S. Coast Guard

P.O. Box 97

Depoe Bay, OR 97341

(503) 765-2124

U.S. Coast Guard

P.O. Box 1010

Newport, OR 97365

(503) 265-5381

U.S. Coast Guard

P.O. Box 1008

Winchester Bay, OR 97467

(503) 271-2138

U.S. Coast Guard

2000 Connecticut Avenue

North Bend, OR 97459

(503) 756-9220

U.S. Coast Guard

4645 Eel Avenue

Charleston, OR 97420

(503) 888-3266

U.S. Coast Guard

19206 Carpenterville Road

Brookings, OR 97415

U.S. Coast Guard

6767 N. Basin Avenue

Portland, OR 97217

(503) 240-9305

Yaquina Head Outstanding Natural Area 2030 S. Marine Science Drive

Newport, OR 97365

Oregon Dunes National Recreation Area Reedsport, OR 97467
Oregon Islands National Wildlife Refuge 2030 S. Marine Science Drive Newport, OR 97365

(503) $867-4550$

NMFS Office of Enforcement 2030 S. Marine Science Drive Newport, OR 97365 (503) 867-3777

NMFS Office of Enforcement P.O. Box 27 Astoria, OR 97103 (503) 325-5934

NMFS Office of Enforcement Coos Bay

(503) 269-1861

NMFS Office of Enforcement 911 Northeast 11th Avenue, Room 620 Portland, OR 97232 (503) 230-5427

Oregon State Park, Region II 3600 E. Third Street

Tillamook, OR 97141

Oregon State Park, Region III 365 N.E. Fourth Street, Suite A Coos Bay, OR 97420

Oregon State Park, Ocean Beaches

Vick Building 525 Trade Street, S.E.

Salem, OR 97310

Fort Stevens State Park

Hammond, OR 97121

Cape Lookout State Park 13000 Whiskey Creek Road W. Tillamook, OR 97141 
Beverly Beach State Park

198 N.E. 123rd Street

Newport, OR 97365

South Beach State Park

5580 S. Coast Highway

South Beach, OR 97366

Devils Lake State Park

c/o Beverly Beach State Park

198 N.E. 123rd Street

Newport, OR 97365

Jessie M. Honeyman State Park

84505 Highway 101 South

Florence, OR 97439

Sunset Bay State Park

10965 Cape Arago Highway

Coos Bay, OR 97420

Bullards Beach State Park

P.O. Box 25

Bandon, OR 97411

Cape Blanco State Park

P.O. Box 1345

Port Orford, OR 97465

Harris Beach State Park

1655 Highway 101

Brookings, OR 97415

Department of Biology

Portland State University

Portland, OR 97207

(503) 464-3851

\section{Washington}

NMFS Northwest Regional Office

7600 Sand Point Way, N.E.

BIN C15700, Bldg. 1

Seattle, WA 98115-0070

(206) 526-6733
NMFS Northwest Fisheries Science Center 2725 Montlake Blvd., E.

West Building, Room 363

Seattle, WA 98112

(206) $860-3200$

NMFS Enforcement

P.O. Box 2369

Bellingham, WA 98227

(360) 676-9268

NMFS Enforcement

138 W. 1st Street, Room 209

Port Angeles, WA 98362

(360) 457-0229

National Marine Mammal Laboratory

7600 Sand Point Way, N.E.

Seattle, WA 98115-0070

(206) $526-4045$

Cascadia Research Collective

Waterstreet Building, Suite 201

$218 \frac{1}{2}$ W. Fourth Avenue

Olympia, WA 98501

(360) 943-7325

Washington Department of Fish and Wildlife 7810 Phillips Road, S.W.

Tacoma, WA 98498

(206) 589-7235

Washington State Patrol

4242 Martin Way

Olympia, WA 98504

The Whale Museum

P.O. Box 945

Friday Harbor, WA 98250

(360) $378-4710$

Whale Hotline--1-800-562-8832

Wolf Hollow Wildlife Rehabilitation Centre P.O. Box 391

Friday Harbor, WA 98250

(360) 378-5000 
Sardis Wildlife Center

7472 Valley View Road

Ferndale, WA 98248

(360) 366-3863

Pt. Defiance Zoo and Aquarium

5400 N. Pearl Street

Tacoma, WA 98407

(206) 591-5337

Ocean Shores Police Department

P.O. Box 100

Ocean Shores, WA 98569

San Juan Islands National Wildlife Refuge

100 Brown Farm Road

Olympia, WA 98506

(360) 753-9467

Olympic Coast National Marine Sanctuary

138 W. First Street

Port Angeles, WA 98362-2600

(360) 457-6622

Nisqually National Wildlife Refuge

100 Brown Farm Road

Olympia, WA 98506

(360) 753-9467

Dungeness National Wildlife Refuge

33 S. Barr Road

Port Angeles, WA 98382

Fort Canby State Park

P.O. Box 488

Ilwaco, WA 98624

(360) 642-3078

Ocean City State Park

148 State Route 115

Hoquiam, WA 98550

(360) 289-3553

Twin Harbors State Park

Westport, WA 98595

(360) 268-9717
Fort Flagler State Park

Nordland, WA 98358

(360) 385-1259

Camano Island State Park

2269 Lowell Point Road

Stanwood, WA 98292

(360) 387-3031

Deception Pass State Park 5175 NSH 20

Oak Harbor, WA 98277

(360) 675-2417

Fort Casey State Park

1280 S. Fort Casey Road

Coupeville, WA 98239

(360) 678-4519

Fort Ebey State Park 395 N. Fort Ebey Road Coupeville, WA 98239

(360) 678-4636

Larrabee State Park 245 Chuckanut Drive Bellingham, WA 98226 (360) 676-2093

Moran State Park

Star Route, Box 22

East Sound, WA 98245

(360) 376-2326

Sequim Bay State Park 1872 Highway $101 \mathrm{E}$.

Sequim, WA 98382

(360) 683-4235

South Whidby State Park 4128 Smugglers Cove Road Freeland, WA 98249 (360) 331-4559 
Sucia Island State Park

Star Route, Box 177

Olga, WA 98279

(360) 376-2073

Olympic National Park

Rural Route 1, Box 5749

Forks, WA 98331

(360) $374-5450$

Marine Animal Resource Center 2201 34th Avenue, W.

Seattle, WA 98199

(206) 285-7325

U.S. Coast Guard

13th District

915 2nd Avenue

Seattle, WA 98174

(206) 220-7090

U.S. Coast Guard

Neah Bay Coast Guard Station

Neah Bay, WA 98357

(360) 645-2236

U.S. Coast Guard

Gray's Harbor Coast Guard Station

Westport, WA 98595

(360) 268-0121

U.S. Coast Guard

Cape Disappointment Coast Guard Station

P.O. Box 460

Ilwaco, WA 98624

(360) 642-2382 


\section{NMFS ALASKA REGION}

The NMFS Alaska Stranding Coordinator is in the Alaska Regional Office, Juneau, AK, (907) 586-7510. Stranding Network participants include:

NMFS Alaska Regional Office

P.O. Box 21668

Juneau, AK 99802-1668

(907) $586-7510$

NMFS Anchorage Office 222 West 7 th, \#43

Anchorage, AK 99513

(907) 271-5006

NMFS Kodiak Office

P.O. Box 1903

Kodiak, AK 99615

(907) $487-4961$

NMFS Dutch Harbor Office

P.O. Box 946

Dutch Harbor, AK 99692

(907) 581-2062

Jan Straley

Sitka

Tory O'Connell

Sitka

Glacier Bay National Park

P.O. Box 140

Gustavus, AK 99826

(907) 697-2230

University of Alaska Museum

907 Yukon Drive

Fairbanks, AK 99775-1200

(907) 474-6947

\author{
Alaska Department of Fish and Game \\ Division of Wildlife Conservation \\ 1300 College Road \\ Fairbanks, AK 99701 \\ (907) 456-5156
}

Beth Mathews

University of Alaska-Southeast

Education and Liberal Arts and Sciences

11120 Glacier Highway

Juneau, AK 99801

(907) 465-6407

Elizabeth Kunibe

Marine Wildlife Rescue Team, Inc.

9503 Antler Way

Juneau, AK 99801

Gary Freitag

Ketchikan

Kate Wynne

MAP, FITC

900 Trident Way

Kodiak, AK 99615

(907) 486-1517

Alaska Maritime National Wildlife Refuge 2355 Kachemak Bay Drive, Suite 101

Homer, AK 99603

(907) 235-6546

Alaska Maritime National Wildlife Refuge Aleutian Islands Unit

FPO AP 96506-5251

Izembeck National Wildlife Refuge

P.O. Box 127

Cold Bay, AK 99571

(907) 532-2445 
Katmai National Park

P.O. Box 7

King Salmon, AK 99613

(907) 246-3305

North Gulf Oceanic Society

P.O. Box 15244

Homer, AK 99603

(907) 235-6590

Glacier Ranger Station

Chugach National Forest

P.O. Box 129

Girdwood, AK 99587

(907) 783-3242

Alpine Veterinary Clinic

12531 Seward

Anchorage, AK 99515

(907) $345-1515$

Anchorage Zoo

4731 O'Malley Road

Anchorage, AK 99516

(907) $346-2133$

Beth Trowbridge

Prince William Sound Science Center

P.O. Box 705

Cordova, AK 99574

(907) 424-5800

Marian Beck

Halibut Cove

Department of Wildlife Management

North Slope Borough

P.O. Box 69

Barrow, AK 99723

(907) 852-2611

Marine Mammals Management U.S. Fish and Wildlife Service 1011 East Tudor Road

Anchorage, AK 99503-6199

(907) 786-3800
Kenai Fjords National Park

P.O. Box 1727

Seward, AK 99664

(907) 224-3175 


\section{ADDENDUM B \\ FEDERAL AGENCIES WITH BEACHFRONT AUTHORITY}

Maine

Acadia National Park

Bar Harbor

Rachel Carson National Wildlife Refuge Wells

Pond Island National Wildlife Refuge

Franklin Island National Wildlife Refuge

Calais

Seal Island National Wildlife Refuge

Cross Island National Wildlife Refuge

Calais

Petit Manan National Wildlife Refuge

Calais

\section{Massachusetts}

Cape Cod National Seashore

South Wellfleet

Nomans Land Island National Wildlife

Refuge

Nantucket National Wildlife Refuge

Newburyport

Monomy National Wildlife Refuge

Newburyport

Thacher Island National Wildlife Refuge

Parker River National Wildlife Refuge Newburyport

\section{Rhode Island}

Block Island National Wildlife Refuge Charlestown

Sachuest Point National Wildlife Refuge Charlestown

Ninigret National Wildlife Refuge Charlestown

Trustom Pond National Wildlife Refuge Charlestown

Connecticut

Salt Meadow National Wildlife Refuge Charlestown, RI

\section{New York}

Gateway National Recreation Area Brooklyn

Fire Island National Seashore

Patchogue

Amagansett National Wildlife Refuge

Wertheim National Wildlife Refuge

Conscience Point National Wildlife Refuge

Morton National Wildlife Refuge

Sag Harbor

Oyster Bay National Wildlife Refuge Shirley

Target Rock National Wildlife Refuge Shirley 


\section{New Jersey}

Cape May National Wildlife Refuge

Edwin B. Forsythe National Wildlife Refuge Oceanville

Barnegat National Wildlife Refuge

Barnegat

\section{Maryland}

Assateague Island National Seashore

Berlin

\section{Virginia}

Back Bay National Wildlife Refuge

Virginia Beach

Plum Tree Island National Wildlife Refuge

Eastern Shore of Virginia National Wildlife Refuge

Wallops Island National Wildlife Refuge

Chincoteague National Wildlife Refuge

Chincoteague

\section{North Carolina}

Cape Hatteras National Seashore

Manteo

Cape Lookout National Seashore

Beaufort

Pea Island National Wildlife Refuge

Rodanthe

Cedar Island National Wildlife Refuge

Swanquarter

Swanquarter National Wildlife Refuge

Swanquarter
Camp LeJeune Marine Corps Base

Camp LeJeune

\section{South Carolina}

Cape Romain National Wildlife Refuge Awendaw

Currituck National Wildlife Refuge

MacKay Island National Wildlife Refuge

Knotts Island

\section{Georgia}

Cumberland Island National Seashore St. Marys

Blackbeard Island National Wildlife Refuge Savannah

Harris Neck National Wildlife Refuge Savannah

Savannah National Wildlife Refuge

Savannah

Tybee National Wildlife Refuge

Savannah

Wolf Island National Wildlife Refuge Savannah

Wassaw Island National Wildlife Refuge Savannah

Grays Reef National Marine Sanctuary

Savannah

\section{Florida}

Biscayne National Park

Homestead 
Canaveral National Seashore

Titusville

Gulf Islands National Seashore

Gulf Breeze

Fort Jefferson National Monument

Homestead

Rookery Bay National Estuarine Research

Reserve

Naples

Merritt Island National Wildlife Refuge

Titusville

Pelican Island National Wildlife Refuge

Titusville

Hobe Sound National Wildlife Refuge

Hobe Sound

Great White Heron National Wildlife Refuge Big Pine Key

Key West National Wildlife Refuge

Big Pine Key

National Key Deer Wildlife Refuge

Big Pine Key

J.N. "Ding" Darling National Wildlife Refuge

Sanibel

Caloosahatchee National Wildlife Refuge Sanibel

Island Bay National Wildlife Refuge Sanibel

Matlacha Pass National Wildlife Refuge Sanibel

Pine Island National Wildlife Refuge Sanibel
Egmont Key National Wildlife Refuge Homosassa

Chassahowitzka National Wildlife Refuge Homosassa

Cedar Keys National Wildlife Refuge Homosassa

Crystal River National Wildlife Refuge Homosassa

Passage Key National Wildlife Refuge Homosassa

Pinellas National Wildlife Refuge

Homosassa

St. Marks National Wildlife Refuge

St. Marks

St. Vincent National Wildlife Refuge Apalachicola

\section{Puerto Rico}

Desecho National Wildlife Refuge Boqueron

Cabo Rojo National Wildlife Refuge Boqueron

Culebra National Wildlife Refuge

Boqueron

\section{Virgin Islands}

Buck Island National Wildlife Refuge Boqueron, PR

Green Cay National Wildlife Refuge Boqueron, PR

Sandy Point National Wildlife Refuge Boqueron, PR 


\section{Alabama}

Bon Secour National Wildlife Refuge

Gulf Shores

Mississippi

Gulf Islands National Seashore

Ocean Springs

\section{Louisiana}

Breton National Wildlife Refuge

Venice

Texas

Padre Island National Seashore

Corpus Christi

McFaddin and Texas Point National Wildlife Refuge

Anahuac

Anahuac National Wildlife Refuge

Anahuac

Brazoria National Wildlife Refuge

Angleton

San Bernard National Wildlife Refuge

Angleton

Aransas National Wildlife Refuge

Austwell

\section{California}

Channel Islands National Park

Ventura

Redwood National Park

Crescent City

Point Reyes National Seashore

Point Reyes
Golden Gate National Recreation Area

San Francisco

Cabrillo National Monument

San Diego

Santa Monica Mountains National Recreation Area

Woodland Hills

Channel Islands National Marine Sanctuary

Santa Barbara

Gulf of the Farallones National Marine Sanctuary

San Francisco

Monterey Bay National Marine Sanctuary

Monterey

San Francisco Bay National Wildlife Refuge Newark

Humboldt Bay National Wildlife Refuge

Newark

San Pablo Bay National Wildlife Refuge

Newark

Vandenberg Air Force Base

Vandenberg Air Force Base

Point Mugu Naval Air Station

Pt. Mugu

Naval Weapons Station

Seal Beach

Long Beach Naval Station

Long Beach

Camp Pendleton Marine Corps Base

Camp Pendleton

Naval Ocean Systems Center

San Diego 
Naval Air Station

San Diego

Naval Amphibious Base

Coronado

\section{Hawaii}

Haleakala National Park

Makawao

Hawaiian Islands Humpback Whale National Marine Sanctuary

Kihei

Hawaiian Islands National Wildlife Refuge

Honolulu

Hanalei National Wildlife Refuge

Kauai

Kilauea National Wildlife Refuge

Kauai

James C. Campbell National Wildlife Refuge Honolulu

Kakahaia National Wildlife Refuge Honolulu

Midway National Wildlife Refuge

Honolulu

Johnston Atoll National Wildlife Refuge Honolulu

Rose Atoll National Wildlife Refuge Honolulu

Howland Island National Wildlife Refuge Honolulu

Baker Island National Wildlife Refuge Honolulu

National Park Service, National War

Memorial of the Pacific

Agana

Pearl Harbor Naval Base

Pacific Missile Range Facility

Barking Sands, Kauai

Kaneohe Marine Corps Air Station

Kaneohe, Oahu

Hickam Air Force Base

Honolulu

Barbers Point Naval Air Station

Barbers Point, Oahu

Anderson Air Force Base

Guam

Wake Island Air Force Base

Wake Island

\section{Oregon}

Suislaw National Forest

Corvallis

Oregon Dunes National Recreation Area

Reedsport

Yaquina Head Natural Area

Newport

Oregon Islands National Wildlife Refuge Newport

Three Arch Rocks National Wildlife Refuge

Cape Meares National Wildlife Refuge Corvallis

\section{Washington}


Olympic National Park

Forks

Willapa National Wildlife Refuge

Ilwaco

Copalis National Wildlife Refuge

Quillayute Needles National Wildlife Refuge

Flattery Rocks National Wildlife Refuge

Jones Island National Wildlife Refuge

San Juan Islands National Wildlife Refuge

Olympia

Nisqually National Wildlife Refuge

Olympia

Dungeness National Wildlife Refuge

Port Angeles

Olympic Coast National Marine Sanctuary

Port Angeles

Bangor Naval Submarine Base

Silverdale

\section{Alaska}

Glacier Bay National Park

Gustavus

Kenai Fjords National Park

Seward

Lake Clark National Park

Anchorage

Katmai National Park

King Salmon

Chugach National Forest

Anchorage
Tongass National Forest

Petersburg

Bering Land Bridge National Preserve Nome

Cape Krusenstern National Monument Kotzebue

Alaska Maritime National Wildlife Refuge (all units)

Homer

Alaska Peninsula National Wildlife Refuge King Salmon

Becharof National Wildlife Refuge

King Salmon

Izembeck National Wildlife Refuge

Cold Bay

Kodiak National Wildlife Refuge

Kodiak

Kenai National Wildlife Wildlife Refuge

Soldotna

Togiak National Wildlife Refuge

Dillingham

Yukon Delta National Wildlife Refuge

Bethel

Arctic National Wildlife Refuge

Fairbanks 


\section{ADDENDUM C}

\section{STATE WILDLIFE RESOURCE AGENCIES}

Maine Department of Marine Resources

Augusta, ME

(207) 624-6550

New Hampshire Department of Fish and Game

Concord, $\mathrm{NH}$

(603) 271-3421

Massachusetts Department of Natural

Resources

Division of Fisheries and Wildlife

Boston, MA

(617) 727-3151

Connecticut Department of Environmental

Protection

Hartford, CT

(203) 566-7404

Rhode Island Department of Environmental Management

Division of Marine Fisheries

Providence, RI

(401) 294-4524

New York Department of Environmental

Conservation

Division of Marine Resources

Albany, NY

(516) 751-7775

New Jersey Department of Environmental

Protection and Energy

Division of Fish Game and Wildlife

Trenton, NJ

(609) 292-2965

Delaware Division of Fish and Wildlife

Dover, DE

(302) $739-4782$
Maryland Department of Natural Resources Oxford, MD

(410) 226-5193

Virginia Department of Game and Inland Fisheries

Richmond, VA

(804) $367-1000$

Virginia Marine Resources Commission Newport News, VA

(804) 247-2200

North Carolina Department of

Environmental Health, and Natural

Resources

Division of Marine Fisheries

Morehead City, NC

(919) 726-7021

North Carolina State Office of Marine Affairs

417 N. Blount Street

Raleigh, NC 27601

(919) $733-2290$

South Carolina Wildlife and Marine

Resources Department

Charleston, SC

(803) 795-6350

Florida Department of Environmental Protection

Marine Mammal Pathobiology Laboratory

St. Petersburg

(813) 893-2904 
Alabama Department of Conservation and Natural Resources

Division of Marine Resources

Dauphin Island, $\mathrm{AL}$

(205) 861-2882

Mississippi Bureau of Marine Resources

Biloxi, MS

(601) $385-5860$

Louisiana Department of Wildlife and Fisheries

Louisiana Natural Heritage Program

Baton Rouge, LA

(504) 765-2821

Texas Department of Parks and Wildlife Division of Fisheries and Wildlife

Austin, TX

(512) $389-4971$

Puerto Rico Department of Natural

Resources

P.O. Box 5887

Puerta de Tierra Station

San Juan, PR 00906

(809) 724-8774

Virgin Islands Department of Planning and Natural Resources

Suite 231, Nisky Center

St. Thomas, VI 00803

(809) $774-3320$

California Department of Fish and Game Marine Resources Division

Sacramento, CA

(916) 445-8386

Hawaii Department of Land and Natural Resources

Division of Aquatic Resources

Honolulu, HI

(808) $587-0100$
Guam Division of Aquatic and Wildlife Resources

Agana, GU

671, 734-3944

Oregon Department of Fish and Wildlife Newport, OR

(503) $867-4741$

Washington Department of Fish and Wildlife Tacoma

(206) 589-7235

Alaska Department of Fish and Game Division of Wildlife Conservation Marine Mammals Coordinator

Fairbanks, AK (907) 456-5156 


\section{ADDENDUM D}

\section{STATE PUBLIC HEALTH AGENCIES}

Maine Department of Human Resources

State House Station 11

Augusta, ME 04333

New Hampshire Department of Health and Human Services

6 Hazen Drive

Concord NH 03301

Massachusetts Department of Public Health 150 Tremont Street, 10th Floor

Boston, MA 02111

Connecticut Department of Public Health and Addiction Services

150 Washington Street

Hartford, CT 06106

Rhode Island Department of Health

Cannon Bldg, 3 Capitol Hill, Room 401

Providence, RI 02908

New York State Department of Health

Corning Tower Bldg, Empire State Plaza,

Room 1482

Albany, NY 12237

New Jersey Department of Health

CN 360

Trenton, NJ 08625

Division of Public Health

Delaware Department of Health and Social Services

P.O. Box 637

Dover, DE 19903

Maryland Department of Health and Mental Hygiene

201 West Preston Street

Baltimore, MD 21201
Virginia Department of Health

1500 East Main Street, Suite 214

P.O. Box 2448

Richmond, VA 23219

North Carolina Department of Environmental, Health and Natural Resources

P.O. Box 27687

Raleigh, NC 27611

South Carolina Department of Health and Environmental Control

2600 Bull Street

Columbia, SC 29201

Georgia Department of Human Resources

2 Peachtree Street, NE, Suite 7-300

Atlanta, GA 30303

Florida Department of Health and Rehabilitation Services

1323 Winewood Blvd.

Tallahassee, FL 32399

Alabama Department of Public Health 434 Monroe Street

Montgomery, AL 36130

Mississippi State Department of Health

P.O. Box 1700

Jackson, MS 39215

Louisiana Department of Health and Hospitals

P.O. Box 3214

Baton Rouge, LA 70821

Texas Department of Health 1100 West 49th Street

Austin, TX 78756 
Puerto Rico Department of Health

P.O. Box 70184

San Juan, PR 00936

Virgin Islands Department of Social and Health Services

St. Thomas Hospital

St. Thomas, VI 00802

California Department of Health Services 714 P Street, Room 1253

Sacramento, CA 95814

Hawaii Department of Health

1250 Punchbowl Street

P.O. Box 3378

Honolulu, HI 96801

Guam Department of Public Health and Social Services

P.O. Box 2816

Agana, GU 96910

Oregon Health Division

800 NE Oregon Street, \#21, Suite 950

Portland, OR 97232

Washington Department of Social and Health Services

P.O. Box 47890

Olympia, WA 98504

Alaska Department of Health and Social Services

P.O. Box 110610

Juneau, AK 99811 


\section{ADDENDUM E}

\section{NATIVE AMERICAN ORGANIZATION CONTACTS}

Washington

Quinault Tribe

P.O. Box 189

Tahola, WA 98587

(360) 276-8211

Hoh Tribe

HC80, Box 917

Forks, WA 98331

(360) 374-6582

Quileute Tribe

P.O. Box 279

LaPush, WA 98350

(360) 374-6163

Makah Tribe

P.O. Box 115

Neah Bay, WA 98357

(360) 645-2205

Lower Elwha S'Klallam Tribe

2851 Lower Elwha Road

Port Angeles, WA 98362

(360) 452-8471

Jameston S'Klallam Tribe

305 Old Blyn Highway

Sequim, WA 98382

(360) 683-1109

Port Gamble S'Klallam Tribe

P.O. Box 280

Kingston, WA 98346

(360) 297-2646

Skokomish Tribe

N. 80 Tribal Center Road

Shelton, WA 98584

(360) 426-4232
Suquamish Tribe

P.O. Box 498

Suquamish, WA 98392

(206) 598-3311

Squaxin Island Tribe

West 81 Highway 108

Shelton, WA 98584

(360) 426-9781

Tulalip Tribe 6700 Totem Beach Road

Marysville, WA 98270

(360) 653-4585

Swinomish Tribe

P.O. Box 817

LaConner, WA 98257

(360) 466-3163

Lummi Tribe

2616 Kwina Road

Bellingham, WA 98226

(360) 734-8180

Alaska

Alaska and Inuvialuit Beluga Whale

Committee

c/o North Slope Borough

P.O. Box 69

Barrow, AK 99723

Alaska Eskimo Whaling Commission

P.O. Box 570

Barrow, AK 99723

Alaska Nanuuq Commission

P.O. Box 69

Barrow, AK 99723 
Alaska Native Harbor Seal Commission P.O. Box 1005

Cordova, AK 99574

Alaska Sea Otter Commission

P.O. Box 83177

Fairbanks, AK 99708

Arctic Marine Resources Commission c/o NANA Regional Corporation

P.O. Box 49

Kotzebue, AK 99752

Cook Inlet Marine Mammal Commission 17414 Monte \#3

Eagle River, AK 99577

Eskimo Walrus Commission

P.O. Box 948

Nome, AK 99762

Indigenous People's Council for Marine Mammals

P.O. Box 200908

Anchorage, AK 99520

Inuit Circumpolar Conference

Calais Building One, Suite 608

3201 C Street

Anchorage, AK 99513

Nome, Elim and Shaktoolik

Beluga Whale Commission

c/o Kawerak Corporation

P.O. Box 948

Nome, AK 99762

Pribilof Aleut Fur Seal Commission

P.O. Box 901

St. Paul, AK 99660
Southeast Native Subsistence Commission

Central Council of Tlingit and Haida

Indian Tribes of Alaska

$320 \mathrm{~W}$. Willoughby Avenue

Juneau, AK 99801

Unalaska Native Fishermen's Association

P.O. Box 591

Unalaska, AK 99685

President

Agdaagux Tribe of King Cove

P.O. Box 38

King Cove, AK 99612

President

Akiachak Native Community

P.O. Box 70

Akiachak, AK 99551

President

Akiak Native Community

P.O. Box 51265

Akiak, AK 99552

Alaska Federation of Natives

Suite 100

1577 C Street

Anchorage, AK 99501

Alaska Native Coalition

P.O. Box 104024

Anchorage, AK 99510-4024

Executive Director

Alaskan Inter-Tribal Council

Suite 225

308 G Street

Anchorage, AK 99501

President

Aleut Community of St. Paul Island

P.O. Box 86

St. Paul Island, AK 99660 
Aleutian-Pribilof Islands Association

Suite 201

401 E. Fireweed Lane

Anchorage, AK 99503-2111

President

Angoon Community Association

P.O. Box 188

Angoon, AK 99820

Chief

Anvik Village

General Delivery

Anvik, AK 99558

President

Association of Village Council Presidents

P.O. Box 219

Bethel, AK 99559

President

Atqasuk Village

General Delivery via

Barrow, AK 99723

Executive Director

Bristol Bay Native Association

P.O. Box 310

Dillingham, AK 99576

President

Caswell Native Association

1202 Old Seward Highway

Anchorage, AK 99515

President

Central Council of Tlingit and Haida Indian

Tribes of Alaska

Suite 300

$320 \mathrm{~W}$. Willoughby Avenue

Juneau, AK 99801

President

Chevak Native Village

P.O. Box 5514

Chevak, AK 99563
President

Chignik Lake Village

P.O. Box 33

Chignik Lake, AK 99548

President

Chilkat Indian Village of Klukwan

P.O. Box 525

Haines, AK 99827-0210

President

Chilkoot Indian Association of Haines

P.O. Box 235

Haines, AK 99827

President

Chinik Eskimo Community

General Delivery

Golovin, AK 99762

Director

Chugachmuit

The North Pacific Rim

$330 \mathrm{C}$ Street

Anchorage, AK 99503

City Manager

City of St. Paul

Pouch 1

St. Paul, AK 99660

President

Cook Inlet Tribal Council

$670 \mathrm{~W}$. Fireweed Lane

Anchorage, AK 99503

Copper River Delta

P.O. Box 1460

Cordova, AK 99574

Executive Director

Copper River Native Association

Drawer $\mathrm{H}$

Copper River, AK 99573 
Vice President

Craig Community Association

P.O. Box 244

Craig, AK 99921

President

Douglas Indian Association

P.O. Box 434

Douglas, AK 99824

President

Egegik Village

P.O. Box 189

Egegik, AK 99579

President

Eklutna Native Village

26339 Eklutna Village Road

Chugiak, AK 99567

President

Ekwok Village

P.O. Box 49

Ekwok, AK 99580

President

Emmonak Village

P.O. Box 126

Emmonak, AK 99581

President

Eyak Native Village

P.O. Box 1388

Cordova, AK 99574

President

Gold Creek-Susitna

Gold Creek via

Talkeetna, AK 99676

President

Gulkana Village

P.O. Box 254

Gakona, AK 99586
President

Hoonah Indian Association

P.O. Box 144

Hoonah, AK 99829

President

Igiugig Village

P.O. Box 4008

Igiugig, AK 99613

Inupiat Community of the Arctic Slope

P.O. Box 934

Barrow, AK 99762

President

Ivanof Bay Village

P.O. Box KIB

Ivanof Bay, AK 99502

President

Kaktovik Village

P.O. Box 8

Kaktovik, AK 99747

Tribal Chairperson

Kenaitze Indian Tribe

P.O. Box 988

Kenai, AK 99611

Chief

King Island Native Community

P.O. Box 992

Nome, AK 99762

President

Knik Village

P.O. Box 872130

Wasilla, AK 99687

President

Kodiak Area Native Association

402 Center Avenue

Kodiak, AK 99615-1277 
President

Kodiak Tribal Council

P.O. Box 1974

Kodiak, AK 99615

President

Kokhanok Village

P.O. Box 1007

Kokhanok, AK 99606

President

Koliganek Village

Koliganek, AK 99576

President

Kongiganak Native Village

P.O. Box 5069

Kongiganak, AK 99559

Kotzebue IRA Council

P.O. Box 296

Kotzebue, AK 99752

President

Levelock Village

General Delivery

Levelock, AK 99625

President

Maniilaq Association

P.O. Box 256

Kotzebue, AK 99752

President

Manokotak Village

P.O. Box 169

Manokotak, AK 99628

President

Mentasta Lake Village

General Delivery

Tok, AK 99780

Metlatka Indian Community

P.O. Box 439

Metlatka, AK 99926
President

Montana Creek Native Association

P.O. Box 200267

Anchorage, AK 99520-0267

Mount Marathon Native Association

P.O. Box 995

Seward, AK 99664

North Slope Borough Department of Wildlife Management

P.O. Box 69

Barrow, AK 99723

President

Naknek Native village

P.O. Box 106

Naknek, AK 99633

President

Nanwalek Village Council

General Delivery

English Bay, AK 99603

Native American Fish and Wildlife Society

Suite 204

4141 B Street

Anchorage, AK 99503

President

Native Village of Chickaloon

P.O. Box 1105

Chickaloon, AK 99674

President

Native Village of Port Heiden

P.O. Box 49007

Port Heiden, AK 99459

President

Native Village Council

P.O. Box 244

Nome, AK 99762 
President

Native Village of Akhiok

P.O. Box 5030

Akhiok, AK 99615

President

Native Village of Akutan

P.O. Box 89

Akutan, AK 99553

President

Native Village of Aleknagik

P.O. Box 115

Aleknagik, AK 99555

President

Native Village of Ambler

P.O. Box 47

Ambler, AK 99786

President

Native Village of Andreafski

P.O. Box 368

St. Mary's, AK 99658

President

Native Village of Atka

Atka Rural Branch

Atka, AK 99502

President

Native Village of Barrow

P.O. Box 1139

Barrow, AK 99723

President

Native Village of Belkofski

General Delivery

Belkofski, AK 99695

Tribal Chairman

Native Village of Bill Moore's Slough

P.O. Box 20037

Kotlik, AK 99620
President

Native Village of Brevig Mission

General Delivery

Brevig Mission, AK 99785

President

Native Village of Buckland

General Delivery

Buckland, AK 99727

President

Native Village of Cantwell

P.O. Box 94

Cantwell, AK 99729

President

Native Village of Chenega

P.O. Box 8079

Chenega, AK 99574

President

Native Village of Chefornak

P.O. Box 29

Chefornak, AK 99561

President

Native Village of Chignik

General Delivery

Chignik, AK 99563

President

Native Village of Chignik Lagoon

General Delivery

Chignik Lagoon, AK 99565

President

Native Village of Chistochina

P.O. Box 241

Gakona, AK 99586

President

Native Village of Chitina

P.O. Box 31

Chitina, AK 99566 
Chief

Native Village of Chuathbaluk

P.O. Box CHU

Chuathbaluk, AK 99557

President

Native Village of Chuloonawick

General Delivery

Chuloonawick, AK 99581

President

Native Village of Crooked Creek

P.O. Box 69

Crooked Creek, AK 99575

President

Native Village of Deering

General Delivery

Deering, AK 99736

President

Native Village of Dillingham

P.O. Box 216

Dillingham, AK 99576

President

Native Village of Diomede

General Delivery

Diomede, AK 99762

President

Native Village of Eek

P.O. Box 087

Eek, AK 99578

President

Native Village of Ekuk

General Delivery

Ekuk, AK 99576

President

Native Village of Elim

P.O. Box 39070

Elim, AK 99739
Vice President

Native Village of False Pass

P.O. Box 29

False Pass, AK 99583

President

Native Village of Gakona

P.O. Box 124

Gakona, AK 99586

President

Native Village of Gambell

P.O. Box 133

Gambell, AK 99742

President

Native Village of Georgetown

General Delivery

Red Devil, AK 99656

President

Native Village of Goodnews Bay

P.O. Box 03

Goodnews Bay, AK 99589

President

Native Village of Hamilton

General Delivery

Kotlik, AK 99620

President

Native Village of Hooper Bay

P.O. Box 2193

Hooper Bay, AK 99604

President

Native Village of Kanatak

c/o BIA Anchorage Agency

1675 C Street

Anchorage, AK 99501

President

Native Village of Karluk

P.O. Box 22

Karluk, AK 99608 
President

Native Village of Kasiglik

P.O. Box 19

Kasiglik, AK 99609

President

Native Village of Kiana

P.O. Box 69

Kiana, AK 99749

President

Native Village of Kipnuk

P.O. Box 57

Kipnuk, AK 99614

President

Native Village of Kivalina

P.O. Box 50051

Kivalina, AK 99750

President

Native Village of Kobuk

General Delivery

Kobuk, AK 99751

Chairman

Native Village of Kotzebue

P.O. Box 296

Kotzebue, AK 99752

President

Native Village of Koyuk

P.O. Box 30

Koyuk, AK 99753

President

Native Village of Kuti-kaah

P.O. Box 68

Copper Center, AK 99573

President

Native Village of Kwigillingok

P.O. Box 49

Kwigillingok, AK 99622
President

Native Village of Kwinhagak

General Delivery

Quinhagak, AK 99655

President

Native Village of Larsen Bay

P.O. Box 35

Larsen Bay, AK 99624

President

Native Village of Marshall

P.O. Box 10

Fortuna Ledge, AK 99585

President

Native Village of Mary's Igloo

P.O. Box 571

Teller, AK 99778

President

Native Village of Mekoryuk

P.O. Box 66

Mekoryuk, AK 99630

President

Native Village of Mountain Village

P.O. Box 32249

Mountain Village, AK 99632

President

Native Village of Napakiak

General Delivery

Napakiak, 'AK 99634

President

Native Village of Napamute

P.O. Box 96

Aniak, AK 99557

President

Native Village of Napaskiak

P.O. Box 6109

Napaskiak, AK 99559 
President

Native Village of Nelson Lagoon

General Delivery

Nelson Lagoon, AK 99571

President

Native Village of Nightmute

General Delivery

Nightmute, AK 99690

President

Native Village of Nikolski

General Delivery

Nikolski, AK 99638

President

Native Village of Noatak

General Delivery

Noatak, AK 99761

Mayor

Native Village of Nuiqsut

General Delivery

Nuiqsut, AK 99723

President

Native Village of Nunapitchuk

P.O. Box 130

Nunupitchuk, AK 99641

President

Native Village of Ouzinkie

P.O. Box 13

Ouzinkie, AK 99644

President

Native Village of Perryville

P.O. Box 101

Perryville, AK 99648

President

Native Village of Piamuit

General Delivery

Hooper Bay, AK 99604
President

Native Village of Pilot Point

P.O. Box 449

Pilot Point, AK 99649

President

Native Village of Pitka's Point

P.O. Box 127

Pitka's Point, AK 99658

President

Native Village of Point Hope

P.O. Box 91

Point Hope, AK 99766

Village Coordinator

Native Village of Point Lay

P.O. Box 101

Point Lay, AK 99759

President

Native Village of Port Lions

P.O. Box 253

Port Lions, AK 99550

President

Native Village of Russian Mission

P.O. Box 09

Russian Mission, AK 99657

President

Native Village of Savoonga

P.O. Box 129

Savoonga, AK 99769

President

Native Village of Scammon Bay

P.O. Box 126

Scammon Bay, AK 99662

President

Native Village of Selawik

P.O. Box 59

Selawik, AK 99770 
President

Native Village of Shaktoolik

General Delivery

Shaktoolik, AK 99771

President

Native Village of Sheldon's Point

General Delivery

Sheldon's Point, AK 99666

President

Native Village of Shishmaref

General Delivery

Shishmaref, AK 99772

President

Native Village of Shungnak

General Delivery

Shungnak, AK 99773

President

Native Village of Solomon

P.O. Box 243

Nome, AK 99762

President

Native Village of St. Michael

General Delivery

St. Michael, AK 99659

President

Native Village of Tanana

P.O. Box 77093

Tanana, AK 99777

President

Native Village of Tooksook Bay

Nelson Island

Tooksook Bay, AK 99637

President

Native Village of Tuntutuliak

P.O. Box 77

Tununak, AK 99681
President

Native Village of Tyonek

P.O. Box 82009

Tyonek, AK 99862-0009

President

Native Village of Unalakleet

P.O. Box 70

Unalakleet, AK 99684

President

Native Village of Wales

General Delivery

Wales, AK 99783

President

Native Village of White Mountain

P.O. Box 84082

White Mountain, AK 99784

President

Native Village of Yakutat

P.O. Box 418

Yakutat, AK 99689

President

New Stuyahok Village

P.O. Box 49

New Stuyahok, AK 99636

President

Newhalen Village

P.O. Box 207

Iliamna, AK 99606

President

Newtok Village

P.O. Box WWT

Newtok, AK 99559

President

Ninilchik Village Traditional Council

P.O. Box 39070

Ninilchik, AK 99639 
President

Nome Eskimo Community

P.O. Box 401

Nome, AK 99762

President

Nondalton Village

General Delivery

Nondalton, AK 99640

President

Noorvik Native Community

P.O. Box 71

Noorvik, AK 99763

President

Organized Village of Kake

P.O. Box 316

Kake, AK 99830-0316

President

Organized Village of Kasaan

General Delivery

Kasaan, AK 99924

President

Organized Village of Kwethluk

P.O. Box 84

Kwethluk, AK 99621

President

Organized Village of Saxman

Route 2, Box 2

Ketchikan, AK 99901

Chairman

Orutsararmuit Native Council

835 Ridgecrest Drive

P.O. Box 927

Bethel, AK 99559

President

Oscarville Traditional Council

P.O. Box 1554

Oscarville, AK 99559
President

Pedro Bay Village

P.O. Box 47020

Pedro Bay, AK 99647

President

Petersburg Indian Association

P.O. Box 1418

Petersburg, AK 99883

President

Pilot Station Traditional Council

P.O. Box 5040

Pilot Station, AK 99650

President

Platinum Traditional Village

General Delivery

Platinum, AK 99651

President

Port Graham Village

P.O. Box PGM

Port Graham, AK 99603-8998

President

Portage Creek Village

General Delivery

Portage Creek, AK 99576

President

Qagan Tayagungin Tribe of Sand Point

P.O. Box 189

Sand Point, AK 99661

President

Qawalingen Tribe of Unalaska

P.O. Box 334

Unalaska, AK 99685

Chief

Rampart Village

P.O. Box 67029

Rampart, AK 99767 
Chairperson

Rural Alaska Resources Association

P.O. Box 200908

Anchorage, AK 99520

President

Seldovia Village Tribe

P.O. Drawer L

Seldovia, AK 99663

Chief

Shageluk Native Village

General Delivery

Shageluk, AK 99665

President

Shoonaq' Tribe of Kodiak

P.O. Box 1974

Kodiak, AK 99615

President

Sitka Tribe of Alaska

456 Katlian Street

Sitka, AK 99835

President

South Naknek Village

P.O. Box 70106

South Naknek, AK 99670

President

St. George Traditional Council

P.O. Box 940

St. George, AK 99660

President

Stebbins Community Association

P.O. Box 2

Stebbins Village, AK 99671

First Chief

Takotna Village

P.O. Box TYC

Takotna, AK 99675
Tanana IRA Council

General Delivery

Tanana, AK 99777

President

Native Village of Tatitlek

P.O. Box 650

Cordova, AK 99574

President

Traditional Village of Teller

P.O. Box 590

Teller, AK 99778

President

Traditional Village of Togiak

P.O. Box 209

Togiak, AK 99678

President

Twin Hills Village

General Delivery

Twin Hills, AK 99576

President

Ugashik Village

General Delivery via

King Salmon, AK 99613

President

Umkumiut Native Village

General Delivery

Nightmute, AK 99690

Administrator

Unalaska IRA Council

Unalaska, AK 99685

President

Valdez Native Association

P.O. Box 1108

Valdez, AK 99686 
President

Village of Alaknut

P.O. Box 167

Aluknut, AK 99554

President

Village of Aniak

P.O. Box 176

Aniak, AK 99557

President

Village of Atmautluak

P.O. Box ATT

Atmautluak, AK 99559

President

Village of Clark's Point

P.O. Box 16

Clark’s Point, AK 99569

President

Village of Iliamna

P.O. Box 286

Iliamna, AK 99606

President

Village of Kalskag

General Delivery

Kalskag, AK 99607

Chief

Village of Kaltag

P.O. Box 9

Kaltag, AK 99748

President

Village of Kotlik

P.O. Box 20096

Kotlik, AK 99620

President

Village of Lower Kalskag

P.O. Box 27

Kalskag, AK 99626
President

Village of Ohogamiut

General Delivery

Fortuna Lodge, AK 99585

President

Village of Old Harbor

P.O. Box 62

Old Harbor, AK 99643

President

Village of Red Devil

P.O. Box 49

Red Devil, AK 99656

President

Village of Alamatof

P.O. Box 2682

Kenai, AK 99611

President

Village of Sleetmute

P.O. Box 21

Sleetmute, AK 99688

President

Village of Stoney River

P.O. Box SRV

Stoney River, AK 99557

President

Village of Wainwright

P.O. Box 184

Wainwright, AK 99782

Yakutat Native Association

P.O. Box 418

Yakutat, AK 99689

President

Kodiak Area Native Association 402 Center Avenue

Kodiak, AK 99615 
Southwest Alaska Municap Conference 3300 Arctic Blvd.

Aneh, Alaska 99503 


\section{ADDENDUM F}

FACILITIES APPROVED FOR HOLDING LIVE STRANDED MARINE MAMMALS

Maine, Massachusetts, and New Hampshire

New England Aquarium

Central Wharf

Boston, MA 02110

(617) 973-5246

Pinnipeds and cetaceans

Connecticut and Rhode Island

Mystic Aquarium

55 Coogan Blvd.

Mystic, CT 06355-1997

(203) 536-9631, Ext. 107

Pinnipeds and cetaceans

\section{New York}

OKEANOS Foundation

431 East Main Street

Riverhead, NY 11901

(516) 369-9840

Pinnipeds and short-term holding of single cetaceans

Aquarium for Wildlife Conservation

Surf Avenue and West 8th Street

Brooklyn, NY 11224

(718) 265-3440

Cetaceans and sea otters*

New Jersey and Delaware

Marine Mammal Stranding Center

P.O. Box 773

Brigantine, NJ 08203

(609) 266-0538

Pinnipeds and short-term holding of single cetaceans

\section{Maryland and Virginia}

National Aquarium in Baltimore

Pier 3, 501 E. Pratt Street

Baltimore, MD 21202

(410) 450-3852

Pinnipeds and cetaceans 


\section{North Carolina}

North Carolina State Aquarium--Roanoke Island

P.O. Box 967

Manteo, NC 27954

(919) 473-3493

Short-term holding of single animals only

North Carolina State Aquarium--Ft. Fisher

P.O. Box 130

Kure Beach, NC 28449

(919) 458-8257

Short-term holding of single animals only

North Carolina State Aquarium--Pine Knoll Shores

P.O. Box 580

Atlantic Beach, NC 28512

(919) 247-4003

Short-term holding of single animals only

\section{Florida}

Marineland of Florida

9507 Ocean Shore Blvd.

Marineland, FL 32086-9602

(904) 471-1111

Cetaceans

Miami Seaquarium

4406 Rickenbacker Causeway

Miami, FL 33149

(305) 361-5705 ext. 240

Cetaceans and manatees

Living Seas/Epcot Center

P.O. Box 10,000

Lake Buena Vista, FL 38830-1000

(407) $560-7688$

Manatees

Sea World of Florida

7007 Sea World Drive

Orlando, FL 32821

(407) 363-2364

Cetaceans and manatees 
Dolphins Plus

P.O. Box 2728

Key Largo, FL 33037

(305) 451-1993

Cetaceans

Dolphin Research Center

P.O. Box 2875

Marathon Shores, FL 33052

(305) 289-0002

Cetaceans

Mote Marine Laboratory

1600 Thompson Parkway

Sarasota, FL 34236

(941) 388-4441

Cetaceans

Lowry Park Zoo

7530 North Blvd.

Tampa, FL 33604

(813) 935-8552

Manatees

Clearwater Marine Science Center

249 Windward Passage

Clearwater, FL 33515

(813) 447-0980

Cetaceans

Homosassa Springs State Wildlife Park 9225 West Fishbowl Drive

Homosassa, FL 32646

(904) 628-5343

Manatees

Gulf World

15412 West Highway 98

Panama City, FL 32407

(904) 234-5271

Cetaceans 
Gulfarium

Highway 98 East

Ft. Walton Beach, FL 32548

(904) 243-9046

Cetaceans

(Can also provide some coverage for Alabama)

\section{Mississippi and Louisiana}

Marine Life Oceanarium

P.O. Box 4078

Gulfport, MS 39502-4078

(601) 864-2511

Cetaceans

(Can also provide some coverage for Alabama)

\section{Texas}

Sea World of Texas

10500 Sea World Drive

San Antonio, TX 78251

(512) 523-3000

Cetaceans

Marine Mammal Research Program

Department of Marine Biology

Texas A\&M University

P.O. Box 1675

Galveston, TX 77553-1675

(409) 740-4455

Cetaceans

University of Texas Marine Science Institute

Port Aransas

Short-term holding of single cetaceans

Gladys Porter Zoo

Brownsville

Short-term holding of single cetaceans

\section{Puerto Rico}

Caribbean Aquatic Animal Health Project

Department of Marine Science

University of Puerto Rico

Apartado 980

Lajas, PR 00667-0908

(809) 899-2048

Cetaceans and manatees 


\section{California}

Northcoast Marine Mammal Center

424 Howe Drive

Crescent City, CA 95531

(707) 464-7448

Pinnipeds

Marine World Africa USA

100 Marine World Parkway

Vallejo, CA 94589

(707) 644-4000, Ext. 242

Cetaceans

Humboldt Wildlife Care Center

Arcata

(707) 826-1583

Short-term holding of pinnipeds

The Marine Mammal Center

Marin Headlands

Golden Gate National Recreation Area

Sausalito, CA 94965

(415) 289-7325

Pinnipeds and sea otters

Long Marine Laboratory

Institute for Marine Studies

University of California

100 Shaffer Road

Santa Cruz, CA 95060

(408) 459-2883

Short-term holding of cetaceans

Monterey Bay Aquarium

886 Cannery Row

Monterey, CA 93940

(408) 648-4829

Sea otters

Santa Barbara Marine Mammal Center 3930 Harold Avenue

Santa Barbara, CA 93110

(805) 687-3255

Pinnipeds 
Fort MacArthur Marine Mammal Care Center

3601 South Gaffey Street

San Pedro, CA 90731

(310) 548-5667

Pinnipeds

Friends of the Sea Lion Marine Mammal Center

20612 Laguna Canyon Road

Laguna Beach, CA 92651

(714) 494-3050

Pinnipeds

Sea World of California

1720 South Shores Road

San Diego, CA 92109

(800) 541-7325

Cetaceans, pinnipeds, and sea otters

\section{Hawaii}

Sea Life Park

Makapuu Point

Waimanalo, HI 96795

Cetaceans and pinnipeds

\section{Oregon}

Oregon Coast Aquarium

P.O. Box 2000

Newport, OR 97365

(503) 867-3474

Pinnipeds and sea otters*

Northwest Wildlife Rehabilitation Center

6265 Brickyard Road

Tillamook, OR 97141

(503) 842-2111

Pinnipeds

Free Flight Wildlife Rehabilitation Center 1185 Portland Avenue

Bandon, OR 97411

(503) 347-3882

Pinnipeds 


\section{Washington}

Marine Animal Resource Center

2201 34th Avenue, W.

Seattle, WA 98199

(206) 285-7325

Pinnipeds

Pt. Defiance Zoo and Aquarium

5400 N. Pearl Street

Tacoma, WA 98407

(206) 591-5337

Cetaceans

Wolf Hollow Wildlife Rehabilitation Center

P.O. Box 391

Friday Harbor, WA 98250

(360) 378-5000

Pinnipeds

\section{Alaska}

Anchorage Zoo

4731 O'Malley Road

Anchorage, AK 99516

(907) 346-2133

Pinnipeds

Alpine Veterinary Clinic 12531 Seward

Anchorage, AK 99515

(907) 345-1515

Pinnipeds and sea otters

Marian Beck

Halibut Cove

Pinnipeds and sea otters

*In the case of California sea otters, those facilities marked with an asterisk are backup facilities to be used with specific authorization from FWS. 


\section{ADDENDUM G \\ SOURCES TO PERFORM GROSS NECROPSY AND \\ TISSUE COLLECTION AND PREPARATION}

For Manatees

Marine Mammal Pathobiology Laboratory

Florida Department of Environmental

Protection

3700 54th Ave., S.

St. Petersburg, FL 33711

(813) 893-2904

\section{For Sea Otters}

National Wildlife Health Center

6006 Schroeder Road

Madison, WI 53711

(608) 264-5411

For Polar Bears, Sea Otters, and Walrus in Alaska

Marine Mammals Management

U.S. Fish and Wildlife Service 1011 East Tudor Road

Anchorage, AK 99503-6199

(907) $786-3800$

National Biological Service

1011 East Tudor Road

Anchorage, AK 99503-6199

(907) $786-3512$

\section{Maine}

Allied Whale

College of the Atlantic

105 Eden Street

Bar Harbor, ME 04609

(207) 288-5015
Massachusetts

New England Aquarium

Central Wharf

Boston, MA 02110

(617) 973-5246

Marine Mammal Investigations

National Marine Fisheries Service

Woods Hole Laboratory

166 Water Street

Woods Hole, MA 02543-1026

(508) 548-5123

Connecticut

Mystic Aquarium

55 Coogan Blvd.

Mystic, CT 06355-1997

(203) 536-9631, Ext. 107

Rhode Island

Dr. Romona Haebler

Environmental Protection Agency

27 Tarzwell Dr.

Narragansett, RI 02882

(401) 782-3095

\section{New York}

OKEANOS Ocean Research Foundation

431 East Main Street

Riverhead, NY 11901

(516) $369-9840$

New Jersey

Marine Mammal Stranding Center

P.O. Box 773

Brigantine, NJ 08203

(609) 266-0538 


\section{Maryland}

National Aquarium in Baltimore

Pier 3, 501 E. Pratt St.

Baltimore, MD 21202

(410) 450-3852

Maryland Department of Natural Resources

Oxford Cooperative Laboratory

904 S. Morris Street

Oxford, MD 21654

(410) 576-3853

Office of Protected Resources

National Marine Fisheries Service

1335 East-West Highway

Silver Spring, MD 20910

(301) 713-2322

\section{District of Columbia}

Dr. James Mead and Mr. Charles Potter

Division of Mammals

National Museum of Natural History

Smithsonian Institution

Washington, DC 20560

(202) 357-1923

Department of Veterinary Pathology

Armed Forces Institute of Pathology

Walter Reed Army Medical Center

Washington, DC 20306-6000

(202) $782-2600$

\section{Virginia}

Virginia Marine Science Museum

717 General Booth Blvd.

Virginia Beach, VA 23451

(804) 437-4949

Virginia Institute of Marine Science

School of Marine Science

College of William and Mary

Gloucester Point, VA 23062

(804) 642-7313

\section{North Carolina}

NMFS Beaufort Laboratory

101 Pivers Island Road

Beaufort, NC 28516-9722

(919) $728-8740$

William McLellan

Biological Sciences

University of North Carolina at Wilmington 601 South College Road

Wilmington, NC 29403

(910) 395-3487

Dr. Andrew Read

Duke University Marine Laboratory

111 Pivers Island Road

Beaufort, NC 28516

(919) 504-7590

\section{South Carolina and Georgia}

NMFS Charleston Laboratory

P.O. Box 12607

Charleston, SC 29422-2607

(803) 762-1200

\section{Florida}

NMFS Southeast Fisheries Science Center 75 Virginia Beach Drive

Miami, FL 33149

(305) $361-4586$

NMFS Panama City Laboratory 3500 Delwood Beach Road Panama City, FL 32408-7403 (904) 234-6541

Marineland of Florida 9507 Ocean Shore Blvd.

Marineland, FL 32086-9602 (904) 471-1111 
Hubbs-Sea World Research Institute

P.O. Box 691-602

Orlando, FL 32869-1602

(407) 363-2662

Miami Seaquarium

4400 Rickenbacker Drive

Miami, FL 33149

(305) 361-5705, Ext. 240

Mote Marine Laboratory

1600 Thompson Parkway

Sarasota, FL 34236

(941) 388-4441

Florida Department of Environmental

Protection

Marine Pathobiology Laboratory

3700 54th Ave., South

St. Petersburg, FL 33711

(813) 893-2904

R.T. Goldston, D.V.M.

3295 62nd Ave., North

St. Petersburg

Gulf World

15412 West Highway 98

Panama City Beach, FL 32407

(904) 234-5271

Gulfarium

Highway 98 East

Fort Walton Beach, FL 32548

(904) 243-9046

EPA Laboratory

Sabine Island

Gulf Breeze, FL 32561-5299

(904) 934-9200

\section{Alabama}

Dr. Gerald Regan

Spring Hill College

4000 Dauphin Street

Mobile, AL 36608

(205) 460-2239

Mississippi and Louisiana

NMFS Pascagoula Laboratory

P.O. Box 1207

Pascagoula, MS 39567

(601) 762-4591

Texas

Dr. Graham Worthy

Texas Marine Mammal Stranding Network

Texas A\&M University

4700 Avenue U, Bldg. 303

Galveston, TX 77550

(409) $740-4721$

Dr. Dan Cowan

Department of Pathology

University of Texas Medical Branch

2.180 John Sealy Hospital E88

Galveston, TX 77550

\section{California}

Vertebrate Museum

Department of Zoology

Humboldt State University

Arcata, CA 95521

(707) $826-4872$

Northcoast Marine Mammal Center

424 Howe Drive

Crescent City, CA 95531

(707) 464-7448 
The Marine Mammal Center

Marin Headlands

Golden Gate National Recreation Area

Sausalito, CA 94965

(415) $289-7325$

Department of Biology

Mendocino Coast Branch

College of the Redwoods

1211 Del Mar Drive

Fort Bragg, CA 95437

(707) $961-1001$

Department of Ornithology and Mammalogy

California Academy of Sciences

Golden Gate Park

San Francisco, CA 94118

(415) $750-7177$

Museum of Vertebrate Zoology

University of California

2593 Life Sciences Building

Berkeley, CA 94720

(415) $642-1379$

Monterey Bay Aquarium

886 Cannery Row

Monterey, CA 93940-1085

(415) 289-7325

(Sea Otters)

Long Marine Laboratory

Institute for Marine Studies

University of California

100 Shaffer Road

Santa Cruz, CA 95060

(408) 459-2883

Moss Landing Marine Laboratories

P.O. Box 450

Moss Landing, CA 95039

(408) 633-3304
Vertebrate Laboratory

Santa Barbara Museum of Natural History 2559 Puesta Del Sol Road

Santa Barbara, CA 93105

(805) 687-4065, Ext. 320

Santa Barbara Marine Mammal Center

3930 Harold Avenue

Santa Barbara, CA 93110

(805) 687-3255

Section of Mammals

Natural History Museum of Los Angeles

County

900 Exposition Blvd.

Los Angeles, CA 90007

(213) 585-5105

Friends of the Sea Lion Marine Mammal Center

20612 Laguna Canyon Road

Laguna Beach, CA 92651

(714) 494-3050

Fort MacArthur Marine Mammal Care

Center

3601 South Gaffey Street

San Pedro, CA 90731

(310) $548-5667$

Department of Animal Care

Sea World

1720 South Shores Road

San Diego, CA 92109

(800) $541-7325$

Southwest Fisheries Science Center

National Marine Fisheries Service

P.O. Box 271

La Jolla, CA 92038

(619) 546-7067

Naval Ocean Systems Center

Code 642

San Diego, CA 92152

(619) 553-1374 


\section{Hawaii}

Dr. Annette Freeman

P.O. Box 1106

Kailua, HI 96734

Dr. David Haas

3113 Oihana St.

Lihue, HI 96766

Dr. Walter Haas

3113 Oihana Street

Lihue, HI 96766

John R. Henderson

Southwest Fisheries Science Center

2570 Dole St.

Honolulu, HI 96822

Dr. Charla Jones

Care Animal Hospital

1135 Kapahulu Ave.

Honolulu, HI 96816

Dr. Roger Kehler

Kihei Veterinary Clinic

P.O. Box 1669

Kihei, HI 96753

Dr. Marta Lepes

Hilo Veterinary Clinic

711 Kanoelehua Ave.

Hilo, HI 96720

Dr. David MacKay

45-480 Kaneohe Bay Drive

Kaneohe, HI 96744

Dr. Michelle Magee

P.O. Box 1106

Kailua, HI 96734

Dr. Robert Morris

420 Uluniu St.

Kailua, HI 96734
Eugene T. Nitta

NMFS, Southwest Region

2570 Dole Street

Honolulu, HI 96822

Dr. Tom Sawa

Division of Animal Industry

Dept. of Agriculture

99-762 Moanalua Road

Aiea, HI 96701

Dr. Thierry Work

U.S. Fish and Wildlife Service

3 Waterfront Plaza, Suite 580

500 Ala Moana Blvd.

Honolulu, HI 96813

Oregon

Robin Brown

Oregon Department of Fish and Wildlife

Marine Science Drive

Newport, OR 97365

(503) $867-4741$

Susan Reimer

Oregon Department of Fish and Wildlife

53 Portway St.

Astoria, OR 97103

Jan Hodder

Oregon Institute of Marine Biology

P.O. Box 5389

Charleston, OR 97420

(503) 888-2581

Bruce Mate

Oregon State University

2030 S. Marine Science Drive

Newport, OR 97365

(503) 270-2381 
Mike Glenn

Oregon Coast Aquarium

P.O. Box 2000

Newport, OR 97365

(503) 867-3474

\section{Washington}

National Marine Mammal Laboratory

National Marine Fisheries Service

7600 Sand Point Way, N.E.

Seattle, WA 98115-0070

(206) 526-4045

Cascadia Research Collective

Waterstreet Bldg., Suite 201

218 1/2 W. Fourth Ave.

Olympia, WA 98501

(360) 943-7325

Steve Jeffries

Washington Department of Fish and Wildlife 7801 Phillips Road, S.W.

Tacoma, WA 98498

(206) 589-7235

Marine Animal Resource Center

2201 34th Ave., W.

Seattle, WA 98199

(206) 285-7325

Alaska

Alaska Department of Fish and Game

Division of Wildlife Conservation

Marine Mammals Coordinator

1300 College Road

Fairbanks, AK 99701

(907) 456-5156

National Marine Fisheries Service

Alaska Regional Office

P.O. Box 21668

Juneau, AK 99802-1668

(907) 586-7510
National Marine Fisheries Service

Anchorage Office

222 West 7th, \#43

Anchorage, AK 99513

(907) 271-5006

National Marine Fisheries Service

Kodiak Office

P.O. Box 1903

Kodiak, AK 99615

(907) 487-4961

Kate Wynne

FITC, MAP

900 Trident Way

Kodiak, AK 99615

(907) 486-1517

Jan Straley

P.O. Box 273

Sitka, AK 99835

Department of Wildlife Management

North Slope Borough

P.O. Box 69

Barrow, AK 99723

(907) 852-2611

North Gulf Oceanic Society

P.O. Box 15244

Homer, AK 99603

(907) 235-6590

University of Alaska Museum

907 Yukon Drive

Fairbanks, AK 99775-1200

(907) 474-6947

Beth Mathews

University of Alaska-Southeast

Education and Liberal Arts and Sciences

11120 Glacier Highway

Juneau, AK 99801

(907) 465-6407 
Gary Freitag

P.O. Box 3181

Ketchikan, AK 99901 


\section{ADDENDUM H \\ VETERINARY ORGANIZATIONS AND COLLEGES}

American Veterinary Medical Association Emergency Preparedness Office 1023 15th Street, N.W., Suite 300

Washington, D.C. 20005-2602

(800) 248-2862, Ext. 287

Dr. Jim McBain

International Association for Aquatic Animal Medicine

c/o Sea World of California

1720 South Shores Road

San Diego, CA 92109

(619) 226-3833

Dr. Wilbur Amand

American Association of Zoological

Veterinarians

c/o Philadelphia Zoological Society

3400 West Girard Avenue

Philadelphia, PA 19104-1960

(215) 387-9094

Dr. David Hunter

American Association of Wildlife

Veterinarians

Idaho Department of Fish and Game

P.O. Box 25

Boise, ID 83707

(208) 454-7638

Dr. David Jessup

Wildlife Disease Association

California Department of Fish and Game

1701 Nimbus Road, Suite D

Rancho Cordova, CA 95670

(916) 355-0237
Except where noted otherwise, veterinary school telephone numbers are for the Dean's Office.

Auburn University

College of Veterinary Medicine

Auburn University, AL 36849

(205) 844-4546

University of California

School of Veterinary Medicine

Davis, CA 95616

(916) $752-1361$

Colorado State University

College of Veterinary Medicine and

Biomedical Sciences

Ft. Collins, CO 80523

(303) 491-7051

Cornell University

College of Veterinary Medicine

Ithaca, NY 14853

(607) 253-3771--Dean's Office

(607) 253-3365--Department of Avian and

Aquatic Animal Medicine

(607) 253-3900--Diagnostic Laboratory

University of Florida

College of Veterinary Medicine

Gainesville, FL 32610-0125

(904) 392-4700, Ext. 5000

University of Georgia

College of Veterinary Medicine

Athens, GA 30602

(706) $542-3461$ 
University of Illinois

College of Veterinary Medicine 2001 South Lincoln

Urbana, IL 61801

(217) $333-2760$

Iowa State University

College of Veterinary Medicine

Ames, IA 50011

(515) 294-1242

Kansas State University

College of Veterinary Medicine Manhattan, KS 66506

(913) 532-5660

Louisiana State University

School of Veterinary Medicine Baton Rouge, LA 70803

(504) 346-3151

Michigan State University

College of Veterinary Medicine

East Lansing, MI 48824-1314

(517) 355-6509

University of Minnesota

College of Veterinary Medicine

St. Paul, MN 55108

(612) 624-9227

Mississippi State University

College of Veterinary Medicine

Mississippi State, MS 39762

(601) 325-1418

University of Missouri

College of Veterinay Medicine

Columbia, MO 65211

(314) $882-3768$
North Carolina State University

College of Veterinary Medicine

4700 Hillsborough Street

Raleigh, NC 27606

(919) 289-4210--Dean's Office

(919) 829-4230--Companion Animals and

Special Species Medicine

Ohio State University

College of Veterinary Medicine

Columbus, $\mathrm{OH} 43210$

(614) 292-1171

Oklahoma State University

College of Veterinary Medicine

Stillwater, OK 74078

(405) 744-6648

College of Veterinary Medicine at Oregon

State University

Corvallis, OR 97331

(503) 737-2098

University of Pennsylvania

School of Veterinary Medicine

3800 Spruce Street

Philadelphia, PA 19104-6044

(215) 898-8841

Purdue University

School of Veterinary Medicine 1240 Lynn Hall

West Lafayette, IN 47907

(317) 494-7607

University of Tennessee

College of Veterinary Medicine

Knoxville, TN 37901

(615) 974-7262

Texas A\&M University

College of Veterinary Medicine

College Station, TX 77843-4461

(409) 845-5053 
Tufts University

School of Veterinary Medicine

200 Westboro Road

North Grafton, MA 01536

(508) 839-5302

Tuskegee University

School of Veterinary Medicine

Tuskegee, AL 36088

(205) 727-8174

Virginia Tech and University of Maryland

Virginia-Maryland Regional College of

Veterinary Medicine

Blacksburg, VA 24061-0442

(703) 231-7910

Washington State University

College of Veterinary Medicine

Pullman, WA 99164

(509) 335-9515

University of Wisconsin-Madison

School of Veterinary Medicine

Madison, WI 53706

(608) 263-6716 



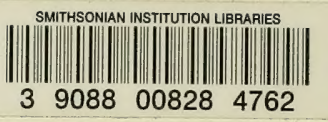

